$4 / 2,23-9685(2)$
ANL/FPP/TM-290

ITER/US/96/IV-BL-5

ANL/FPP/TM-290

ITER/US/96/IV-BL-5

PHYSICAL AND MECHANICAL CHARACTERISTICS AND

CHEMICAL COMPATIBILITY OF ALUMINUM NITRIDE

INSULATOR COATINGS FOR FUSION REACTOR APPLICATIONS

by

K. Natesan and D. L. Rink

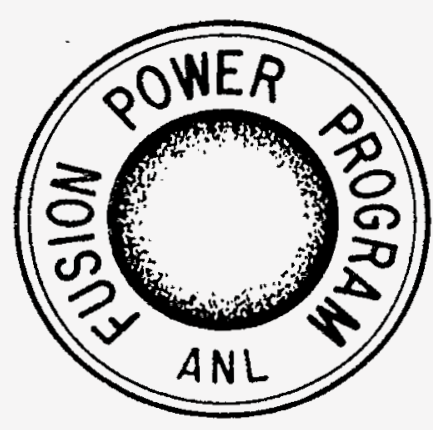

FUSION POWER PROGRAM

Operated by

Argonne National Laboratory 9700 South Cass Avenue Argonne, Illinois 60439

The University of Chicago for the U.S. Department of Energy under Contract W-31-109-Eng-38 
Argonne National Laboratory, with facilities in the states of Illinois and Idaho, is owned by the United States government, and operated by The University of Chicago under the provisions of a contract with the Department of Energy.

\section{DISCLAIMER}

This report was prepared as an account of work sponsored by an agency of the United States Government. Neither the United States Government nor any agency thereof, nor any of their employees, makes any warranty, express or implied, or assumes any legal liability or responsibility for the accuracy, completeness, or usefulness of any information, apparatus, product, or process disclosed, or represents that its use would not infringe privately owned rights. Reference herein to any specific commercial product, process, or service by trade name, trademark, manufacturer, or otherwise, does not necessarily constitute or imply its endorsement, recommendation, or favoring by the United States Government or any agency thereof. The views and opinions of authors expressed herein do not necessarily state or reflect those of the United States Government or any agency thereof.

Reproduced from the best available copy.

Available to DOE and DOE contractors from the Office of Scientific and Technical Information P.O. Box 62

Oak Ridge, TN 37831

Prices available from (423) 576-8401

Available to the public from the National Technical Information Service

U.S. Department of Commerce 5285 Port Royal Road Springfield, VA 22161 
Distribution Category:

Magnetic Fusion Energy Systems

(UC-424)

ANL/FPP/TM-290

ITER/US/96/IV-BL-5

\section{ARGONNE NATIONAL LABORATORY \\ 9700 South Cass Avenue \\ Argonne, Illinois 60439-4838}

\section{PHYSICAL AND MECHANICAL CHARACTERISTICS AND CHEMICAL COMPATIBILITY OF ALUMINUM NITRIDE INSULATOR COATINGS FOR FUSION REACTOR APPLICATIONS}

by

K. Natesan and D. L. Rink

Energy Technology Division

April 1996

Work supported by the Office of Fusion Energy

U.S. Department of Energy, Task T219/220, Electrical Insulation and Testing for Liquid Metal Systems, under Contract W-31-109-Eng-38 


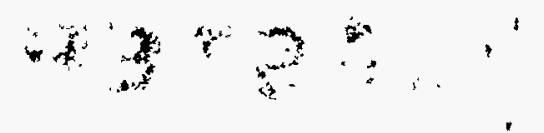




\section{CONTENTS}

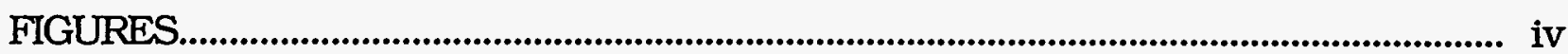

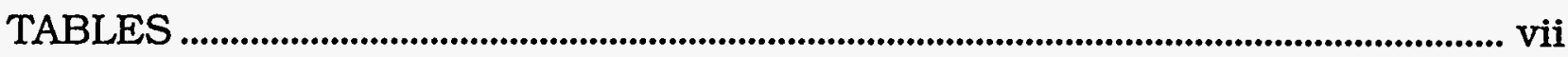

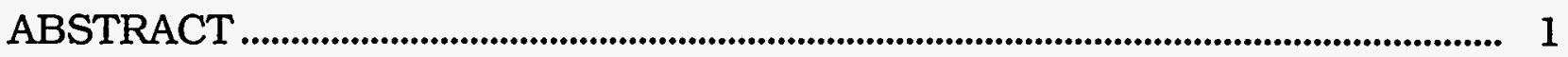

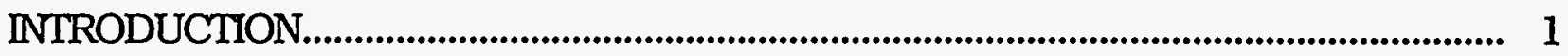

Chemical Compatibility in Liquid Lithium....................................................... 3

Transfer of Metallic Elements................................................................... 3

Transfer of Nonmetallic Elements............................................................. 4

Electrical Insulation Characteristics................................................................ 5

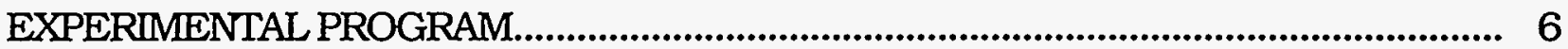

Fabrication of AlN-Coated Specimens................................................................... 6

Aluminizing Processes ........................................................................................... 7

Gas-Phase Nitridation...................................................................................... 7

Physical Vapor Deposition....................................................................................... 8

Coatings by Chemical Route .................................................................................. 9

Chemical Vapor Deposition...................................................................................... 10

Li Test Facility ................................................................................................................. 11

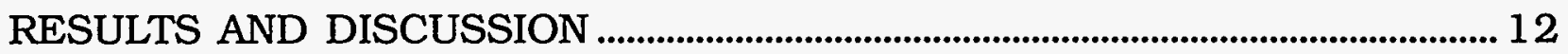

Samples Nitrided in Gas Phase .................................................................................. 12

Characteristics of As-Coated Specimens ............................................................... 18

Physical Vapor Deposition................................................................................... 18

Chemical Vapor Deposition.................................................................................... 18

Coatings by Chemical Route ................................................................ 21

Electrical Insulating Behavior of As-Coated Coatings .......................................... 23

Lithium Compatibility of Coatings.................................................................................. 23

Experiments in Li of Normal Purity .............................................................. 30

Experiments in Li with Higher Activities of $\mathrm{N}$ and/or $\mathrm{Al}$...................... 34

Hardness of AlN Coatings.................................................................................................... 37

Electrical Resistance of Li-Exposed AlN Coatings......................................... 39

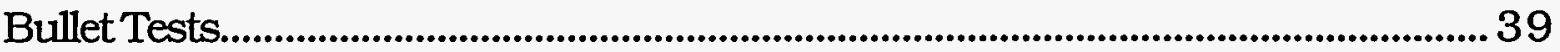

In-Situ Development of AlN Coatings in Li ............................................................ 44

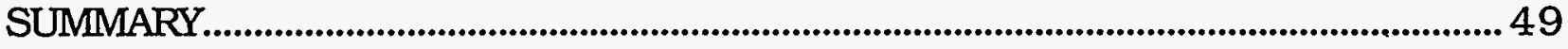

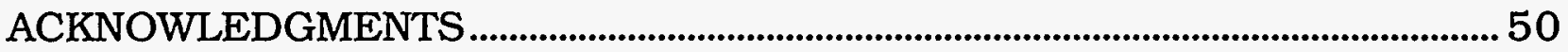

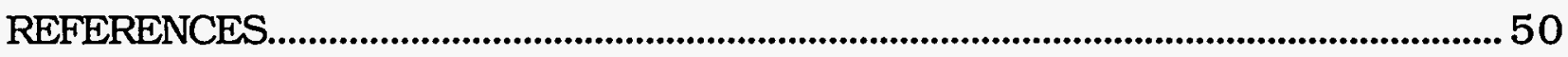




\section{FIGURES}

1. Thermodynamic stability of nitrides of several structural metals in $\mathrm{Li}$ environment

2. Temperature dependence of minimum $\mathrm{N}$ concentration in $\mathrm{Li}$ for nitride formation on several metals.

3. Electrical resistance of several nitrides as a function of coating thickness; requirements for fusion blanket application are shown for reference.

4. Li systems used in present study.

5. Plot of weight change squared vs. exposure time for Type 316 stainless steel nitrided at $800^{\circ} \mathrm{C}$.

6. Plot of weight change squared vs. exposure time for $\mathrm{V}-5 \mathrm{Cr}-5 \mathrm{Ti}$ alloy nitrided at 600 and $800^{\circ} \mathrm{C}$

7. AES spectra for Type 316 stainless steel and V-5Cr-5Ti alloy, nitrided at $800^{\circ} \mathrm{C}$

8. AES depth profiles for elements $\mathrm{Fe}, \mathrm{Cr}, \mathrm{Ni}$, and $\mathrm{N}$ for Type 316 stainless steel nitrides at $800^{\circ} \mathrm{C}$

9. AES depth profiles for $\mathrm{V}-5 \mathrm{Cr}-5 \mathrm{Ti}$ specimen nitrided at $800^{\circ} \mathrm{C} . \ldots \ldots \ldots . . .16$

10. Plot of weight change squared vs. exposure time for aluminized $\mathrm{V}-5 \mathrm{Cr}-5 \mathrm{Ti}$ alloy nitrided at $650^{\circ} \mathrm{C}$.

11. Stability of oxide phases as a function of temperature and oxygen partial pressure.

12. Stability of several nitride phases as a function of temperature and nitrogen pressure depicted in terms of $\mathrm{NH}_{3}$ and $\mathrm{H}_{2}$ partial pressures. Also shown are curves corresponding to 100,500, and $1000 \mathrm{wtppm} N$ in $\mathrm{Li}$

13. SEM photomicrographs and EDX analysis of MRT- and BIRL- and CAT-deposited AlN coating on V-alloy specimens in as-deposited condition

14. SEM photomicrographs of AlN-coated V-alloy specimens after hardening treatment at $900^{\circ} \mathrm{C}$ for $110 \mathrm{~h}$ 
15. SEM photomicrographs of ANL-deposited AlN coated V-alloy specimens in as-deposited condition and EDX analysis of coating layer

16. SEM photomicrograph of AlN surface coated by CVD ................................220

17. SEM photomicrograph of AlN coating developed by chemical route.

18. SEM photomicrographs of AlN coating showing pronounced effect of thickness on cracking.

19. SEM photomicrograph of AlN coating which shows cracks arising from premature decomposition of liquid precursor.

20. Electrical resistance data for AlN-coated specimens in as-coated and hardened conditions

21. SEM photomicrograph in cross section and EDX depth profiles for $\mathrm{Al}, \mathrm{N}, \mathrm{V}, \mathrm{Cr}$, and Ti in ANL-developed, AlN-coated, prealuminized V-5Cr-5Ti alloy specimen after $430 \mathrm{~h}$ exposure in Run 2-6 at $300^{\circ} \mathrm{C}$ to $\mathrm{Li}$ environment of normal purity

22. SEM photomicrographs of cross sections of $900^{\circ} \mathrm{C}-$ hardened AlN-coated specimens after $600 \mathrm{~h}$ exposure in Run 2-8 to $\mathrm{Li}$ environment of normal purity.

23. SEM photomicrographs of cross sections of $700^{\circ} \mathrm{C}$-hardened AlN-coated specimens after $456 \mathrm{~h}$ exposure in Run $2-9$ to $\mathrm{Li}$ environment of normal purity.

24. SEM photomicrographs of cross sections of AlN-coating with $900^{\circ} \mathrm{C}$ hardening on $\mathrm{V}$ alloy, AlN-coating with $900^{\circ} \mathrm{C}$ hardending on prealuminized $\mathrm{V}$ alloy, and pack diffusion $\mathrm{Al}_{2} \mathrm{O}_{3}$ coating on Type 304 stainless steel, after $5000 \mathrm{~h}$ exposure in Run 2-10 at $300^{\circ} \mathrm{C} \mathrm{Li} \mathrm{environment} \mathrm{of} \mathrm{normal} \mathrm{purity.}$

25. SEM photomicrograph in cross section and EDX depth profiles for $\mathrm{Al}, \mathrm{N}, \mathrm{V}, \mathrm{Cr}$, and $\mathrm{Ti}$ for MRT-supplied, AlN-coated V-5Cr-5Ti alloy specimen after $430 \mathrm{~h}$ exposure in Run $3-4$ at $300^{\circ} \mathrm{C}$ to $\mathrm{Li}$ environment in which argon-nitrogen gas was bubbled for $24 \mathrm{~h}$ 
26. SEM photomicrograph in cross section and EDX depth profiles for $\mathrm{Al}, \mathrm{N}, \mathrm{V}, \mathrm{Cr}$, and $\mathrm{Ti}$ in ANL-developed, AlN-coated, prealuminized $\mathrm{V}-5 \mathrm{Cr}-5 \mathrm{Ti}$ alloy specimen after $430 \mathrm{~h}$ exposure in Run $3-4$ at $300^{\circ} \mathrm{C}$ to $\mathrm{Li}$ environment

27. Electrical resistance of several AlN-coated specimens in ascoated and hardened conditions before and after Li exposure

28. Macrophotograph of AlN-coated bullet specimens in as-coated condition and after exposure to Li environment.

29. SEM photomicrographs of cross sections of as-coated bullet along circumference at $0,90,180$, and $270^{\circ}$ orientations.

30. SEM photomicrograph of cross section of flat coupon coated with AIN along with bullet specimens.

31. SEM photomicrographs of surface of Li-exposed bullet specimen showing crack network

32. SEM photomicrographs of cross sections of several A1N-coated specimens after $120 \mathrm{~h}$ exposure in Run $3-8$ at $500^{\circ} \mathrm{C}$ to $\mathrm{Li}$ environment with $\mathrm{N}$ and $\mathrm{Al}$ additions.

33. SEM photomicrographs of cross sections of several AlN-coated specimens after $120 \mathrm{~h}$ exposure in Run $3-9$ at $300^{\circ} \mathrm{C}$ to $\mathrm{Li}$ environment with $\mathrm{N}$ and $\mathrm{Al}$ additions.

34. Regions of stability for $\mathrm{AIN}$ and $\mathrm{LiAl}_{5} \mathrm{O}_{8}$ phases as a function of temperature and $\mathrm{O}$ and $\mathrm{N}$ concentrations in $\mathrm{Li}$.

35. Regions of stability for AlN and $\mathrm{LiAlO}_{2}$ phases as a function of temperature and $\mathrm{O}$ and $\mathrm{N}$ concentrations in $\mathrm{Li}$.

36. Regions of stability for $\mathrm{AIN}$ and $\mathrm{Al}_{2} \mathrm{O}_{3}$ phases as a function of temperature and $\mathrm{O}$ and $\mathrm{N}$ concentrations in $\mathrm{Li}$. 


\section{TABLES}

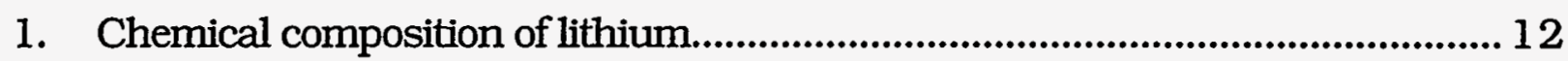

2. Experiments performed in lithium of normal purity .....................................25

3. Experiments performed in lithium with higher activities of nitrogen and/or aluminum......................................................................................... 27

4. Hardness data obtained by nano-indentation technique.............................. 40 


\title{
PHYSICAL AND MECHANICAL CHARACTERISTICS AND CHEMICAL COMPATIBILITY OF ALUMINUM NITRIDE INSULATOR COATINGS FOR FUSION REACTOR APPLICATIONS
}

\author{
K. Natesan and D. L. Rink \\ Energy Technology Division
}

\begin{abstract}
The blanket system is one of the most important components in a fusion reactor because it has a major impact on both the economics and safety of fusion energy. The primary functions of the blanket in a deuterium/tritium-fueled fusion reactor are to convert the fusion energy into sensible heat and to breed tritium for the fuel cycle. The Blanket Comparison and Selection Study, conducted earlier, described the overall comparative performance of various concepts, including liquid metal, molten salt, water, and helium. Based on the requirements for an electrically insulating coating on the first-wall structural material to minimize the MHD pressure drop during the flow of liquid metal in a magnetic field, AlN was selected as a candidate coating material for the $\mathrm{Li}$ self-cooled blanket concept.

This report discusses the results from an ongoing study of physical and mechanical characteristics and chemical compatibility of AlN electrical insulator coatings in a liquid $\mathrm{Li}$ environment. Details are presented on the AlN coating fabrication methods, and experimental data are reported for microstructures, chemistry of coatings, pretreatment of substrate, heat treatment of coatings, hardness data for coatings, coating/lithium interactions, and electrical resistance before and after exposure to lithium. Thermodynamic calculations are presented to establish regions of stability for AlN coatings in an $\mathrm{Li}$ environment as a function of $\mathrm{O}$ concentration and temperature, which can aid in-situ development of AlN coatings in Li.
\end{abstract}

\section{INTRODUCTION}

Liquid metals, including $\mathrm{Li}, \mathrm{Pb}-0.7$ wt.\%Li (Pb-Li), and $\mathrm{Na}-78$ wt.\% $\mathrm{K}$ alloy $(\mathrm{NaK})$, are being considered as coolant/tritium-breeding blankets in several concepts of fusion power reactor. The structural materials considered for the first-wall application in the advanced concepts include V(4 to 5) wt.\%Cr-(4 to 5) wt.\%Ti alloy. In fusion applications, the structural 
material of the system must be compatible with the liquid metal; capable of maintaining structural integrity for long periods while exposed to moderately elevated temperatures, thermal cycling, and possibly intense irradiation; and amenable to low magnetohydrodynamic (MHD) losses during flow in the magnetic field. Key performance variables of importance in application of liquid metals in first wall/blankets are described in Refs. 1 and 2.

The main challenge in the design of self-cooled blankets is to accommodate the strong influence of the magnetic field on the liquid-metal flow. If the flow direction is perpendicular to the field, a potential difference across the duct is induced in the liquid metal. This can cause a large electrical current flow if the potential difference is short-circuited by the duct walls. An electrical current flowing perpendicular to a magnetic field results in a mechanical force that leads to MHD pressure drop. It has been shown that even thin conducting walls would lead to a rather high pressure drop under the conditions of a fusion reactor blanket. For example, the pressure drop in a poloidal duct in an inboard blanket segment would reach $8.6 \mathrm{MPa}$ if the conducting liner was $0.1 \mathrm{~mm}$ thick. ${ }^{3}$ This unacceptably high pressure drop shows the need for electrically insulating coatings in contact with the flowing liquid metal. It has been shown that a perfectly insulating coating on the wall would decrease the pressure drop from 8.6 to $0.22 \mathrm{MPa} .^{3,4}$

Even though a very low pressure drop can be achieved with a perfectly insulating coating, in practice it will be difficult to obtain such a coating because any and all coating methods still yield coatings with defects such as pinholes, cracks, and minute flaws. However, a pressure drop of 1-2 $\mathrm{MPa}$ is acceptable for a liquid-metal blanket in a fusion reactor application and therefore a perfectly insulating coating is not required. Malang and Bühler ${ }^{4}$ made calculations on leakage currents through imperfections in the coatings and concluded that to obtain an acceptable pressure drop for the fusion blanket, the product of coating resistivity and the coating layer thickness should have a minimum value of $0.01 \Omega \cdot \mathrm{m}^{2}$.

Tests were conducted at Argonne National Laboratory (ANL) to evaluate the MHD performance of electrical insulator coatings that use a eutectic liquid metal of composition $\mathrm{Na}-78$ wt.\% $\mathrm{K}(\mathrm{NaK}) .{ }^{5}$ Aluminum oxide was chosen as the candidate insulating material for the proof of concept because it is thermodynamically stable in $\mathrm{NaK}$ (especially below $100^{\circ} \mathrm{C}$ ), which can be used in a vacuum vessel and/or a divertor; and because of the availability of ANL's Liquid Metal Experiment (ALEX) facility, which contains NaK as the working fluid. The inside pipe diameter was $10.8 \mathrm{~cm}$, the wall thickness 
was $2.9 \mathrm{~mm}$, the length of the uniform magnetic field was $\approx 1.8 \mathrm{~m}$, and the maximum magnetic field strength was $2.0 \mathrm{~T}$. Test results showed that the pressure drop with an insulator coating was 25 times smaller than that obtained on an uncoated tube under identical test conditions.

The purpose of this report is to discuss the results from an ongoing study of physical, mechanical, and chemical compatibility of AlN electrical insulator coatings in a liquid $\mathrm{Li}$ environment. Details are presented on the AlN coating fabrication methods, and experimental data are reported for microstructures, chemistry of coatings, pretreatment of substrate, heat treatment of coatings, hardness and adhesion data for coatings, coating/Li interactions, and electrical resistance before and after exposure to $\mathrm{Li}$.

\section{Chemical Compatibility in Liquid Lithium}

Extensive thermodynamic calculations have been performed to evaluate potential electrical-insulator candidates that are chemically compatible in liquid $\mathrm{Li}$ for use as a coating on first-wall and blanket structural material. The issues of compatibility between the liquid $\mathrm{Li}$ and the coating involve the (a) thermodynamic stability of the coating when contacted with the liquid Li; (b) extent of dissolution of the coating in the liquid $\mathrm{Li}$, which is dictated by the solubilities of coating constituents (and structural material constituents, if uncoated material or bimetallic systems are used) in liquid $\mathrm{Li}$ at temperatures and temperature gradients that are present in the system; and (c) degrees of interaction between the coating constituents and the reactants such as oxygen, carbon, nitrogen, and hydrogen in liquid $\mathrm{Li}$, which can result in changes in chemistry of the coating, thereby altering the insulating characteristics.

\section{Transfer of Metallic Elements}

For the advanced blanket in a fusion reactor, V-(4-5)Cr-(4-5)Ti alloy is considered as the candidate structural material for the first wall/blanket application. The peak temperature for the liquid metal in an advanced blanket will be $400-600^{\circ} \mathrm{C}$, with a maximum temperature gradient of $\approx 100^{\circ} \mathrm{C}$ around the loop. Under these conditions, the mass transfer of metallic elements between the structural materials and the liquid metal is determined primarily by the leaching kinetics of the alloy constituents of the materials, which are dictated by the solubility of the alloy constituents in the liquid metal and the temperature dependence of the solubility values. In some instances, the substrate constituents can react with nonmetallic elements such as $\mathrm{O}, \mathrm{C}$, and $\mathrm{N}$ to form stable compounds that can alter the corrosion degradation of the materials. Details pertaining to metallic element mass transfer are discussed in Refs. 1 and 2. 


\section{Transfer of Nonmetallic Elements}

Nonmetallic elements such as $\mathrm{O}, \mathrm{C}, \mathrm{N}$, and $\mathrm{H}$ are known to migrate in structural-material/liquid-metal systems as a result of differences in chemical activity. A detailed analysis has been published earlier $6-8$ on the thermodynamics of nonmetallic impurity elements in $\mathrm{Li}$, with emphasis on purification of the liquid metals and chemical compatibility of candidate structural materials. Because the objective of this research effort is to examine the viability of AlN coating as an electrical insulator, the rest of the report will emphasize the thermodynamic stability, physical and chemical characteristics of the coating, viability of different coating methods, and insulation characteristics of the coatings.

Figure 1 depicts the thermodynamic stability of nitrides of several structural metals with respect to $\mathrm{N}$ concentration in an $\mathrm{Li}$ environment. To determine the distribution coefficients and the initial concentrations of nonmetallic elements in the solid and the liquid, one can assess the tendency for nonmetallic elements to transfer, i.e., from solid to liquid or liquid to solid. One can then evaluate the types of nonmetallic element interactions that are likely to occur and their consequences for material behavior. Figure 2 shows the temperature dependence of $\mathrm{N}$ concentration in $\mathrm{Li}$ that will result in formation of metal nitrides in an $\mathrm{Li}$ environment. For the stability of AlN in an Li environment, the $\mathrm{N}$ concentration in $\mathrm{Li}$ will be dictated by the $\mathrm{Al}$ concentration in $\mathrm{Li}$ because both $\mathrm{N}$ and $\mathrm{Al}$ have fairly high solubilities in $\mathrm{Li}$. Calculations using the free energy value for the reaction

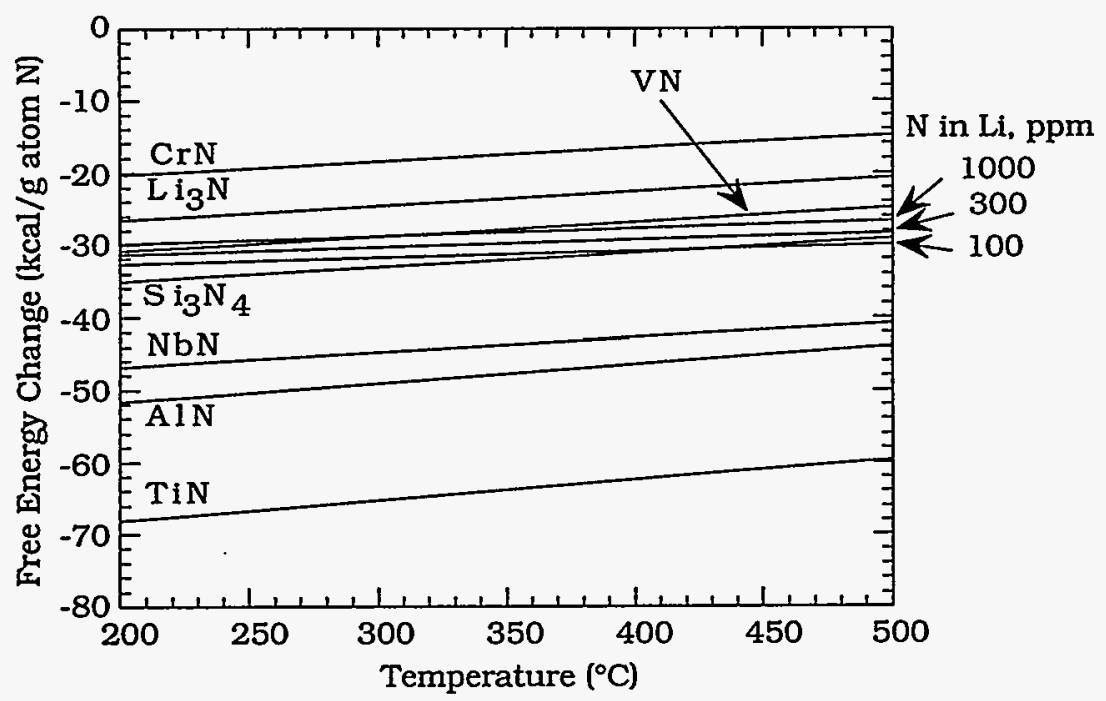

Fig. 1. Thermodynamic stability of nitrides of several structural metals in $\mathrm{Li}$ environment 


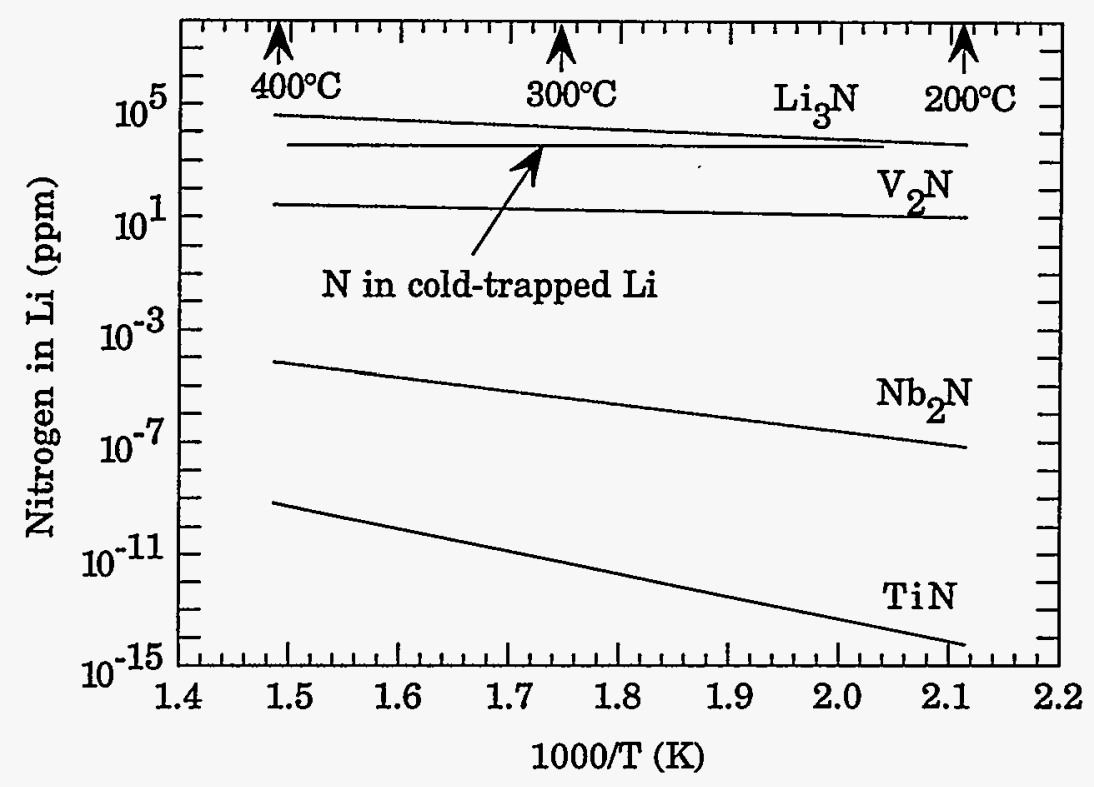

Fig. 2. Temperature dependence of minimum $\mathrm{N}$ concentration in $\mathrm{Li}$ for nitride formation on several metals

AlN $($ solid $)=\operatorname{Al}($ in $\mathrm{Li})+\mathrm{N}(\mathrm{in} \mathrm{Li})$

showed that the product of activities of $\mathrm{N}$ and $\mathrm{Al}$ in $\mathrm{Li}$ required to maintain a stable AlN phase is very low, indicating that dissolution of AlN compound will be small (even though the driving force for dissolution of either $\mathrm{N}$ or $\mathrm{Al}$ alone is large based on their solubility values in $\mathrm{Li}$ ).

\section{Electrical Insulation Characteristics}

A review of available information on electrical resistivity values for nitrides such as AlN and $\mathrm{Si}_{3} \mathrm{~N}_{4}$ shows resistivities of $>10^{5} \Omega \cdot \mathrm{m}$ at temperatures below $\approx 600^{\circ} \mathrm{C}$. The requirement is that the product of the electrical resistivity of the insulator coating and the thickness of the coating should exceed a nominal value of $0.01 \Omega \cdot \mathrm{m}^{2}$ under operating conditions. This translates to a minimum resistivity value of $10^{4} \Omega \cdot \mathrm{m}$ for a coating thickness of $1 \mu \mathrm{m}$, or $10^{3} \Omega \cdot \mathrm{m}$ for a coating thickness of $10 \mu \mathrm{m}$. Based on the resistivity values of nitrides mentioned above, a coating layer of $<1 \mu \mathrm{m}$ in thickness of any of these materials would be adequate from the insulating standpoint, provided that resistivity is not reduced during operation, e.g., by irradiation. Figure 3 shows electrical resistance as a function of coating thickness for nitride materials, along with the requirements for application in a fusion reactor. Superimposed on this figure are lines corresponding to 
different concentrations of $\mathrm{N}$ in $\mathrm{Li}$. It is evident that AlN will be stable in $\mathrm{Li}$ over a wide range of $\mathrm{N}$ concentrations. The calculations show that $\mathrm{Ti}$ in a $\mathrm{V}$

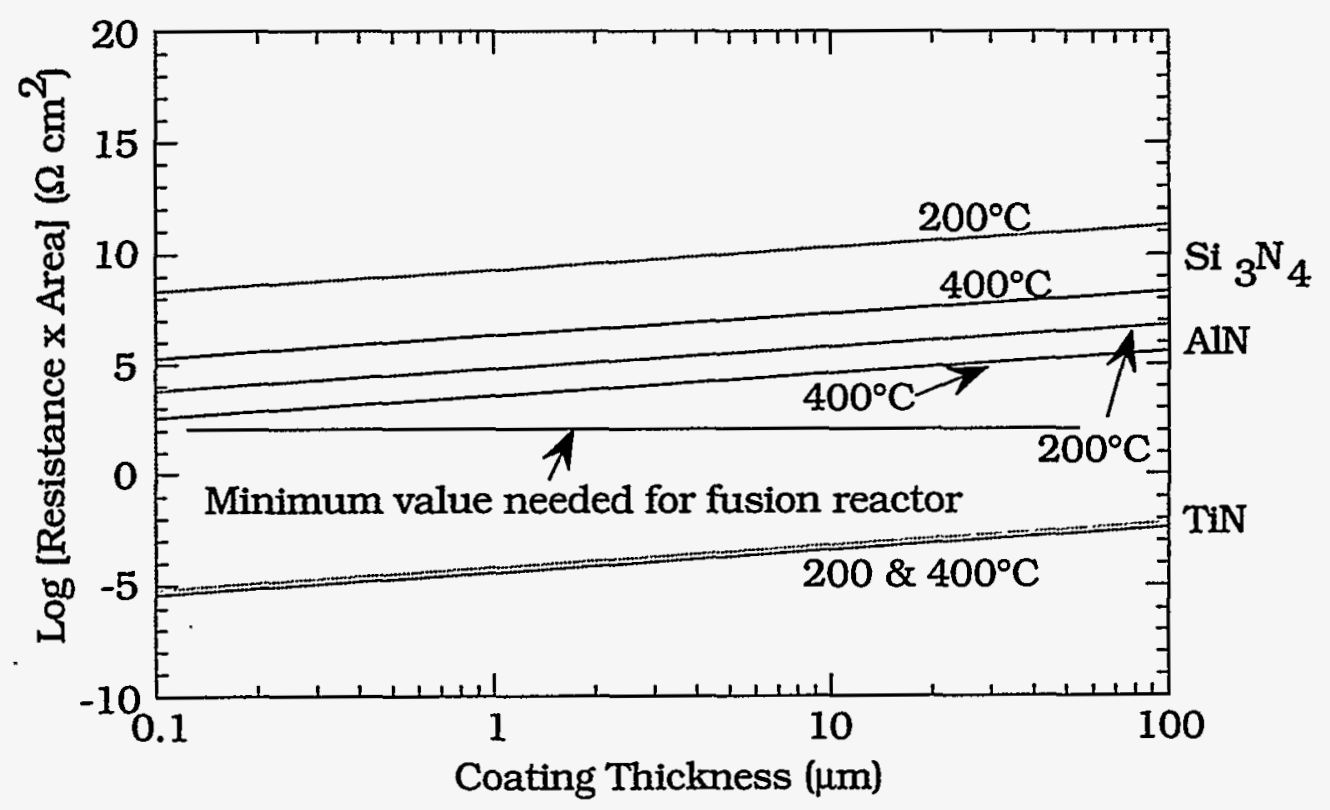

Fig. 3. Electrical resistance of several nitrides as a function of coating thickness; requirements for fusion blanket application are shown for reference

alloy can also form a nitride in the same $\mathrm{Li}$ but that TiN is not viable as an electrical insulator. As a result, it is desirable to aluminize the surface regions of the first-wall alloy and to nitride the surface Al to form the insulating layer. Furthermore, $\mathrm{Al}$ is favored because a reservoir of $\mathrm{Al}$ can be built into the alloy surface by various techniques and if the coating layer cracks or spalls, the Al-enriched surface could be renitrided by $\mathrm{N}$ dissolved in $\mathrm{Li}$.

\section{EXPERIMENTAL PROGRAM}

\section{Fabrication of AlN-Coated Specimens}

Several possible approaches are being examined to develop an AlN coating on the candidate structural material, including prealuminizing the surface of the material by a diffusion process and subsequently converting it to nitride in an external gas atmosphere; using a physical vapor deposition process with and without bond coats; applying a low-temperature electrochemical method that involves sequential reactions; prealuminizing the surface of the alloy and converting it to nitride in a high-nitrogen Li environment; preexposing the material to liquid $\mathrm{Al}$ and converting it to 
nitride in $\mathrm{Li}$; in-situ forming of an AlN coating in $\mathrm{Li}$ with high thermodynamic activities for $\mathrm{Al}$ and $\mathrm{N}$; and prealuminizing specimens of structural material and nitriding them with an $\mathrm{N}_{2}$ cover gas during $\mathrm{Li}$ exposure. Details of some of these processes and the characteristics of the coatings are discussed below.

\section{Aluminizing Processes}

Surface aluminization of the $\mathrm{V}$ alloy is attempted by a pack-diffusion process and by a "hot dipping" technique. In pack-diffusion, the V-alloy substrate materials are brought into contact with a pack of powders and heated for 4-12 $\mathrm{h}$ at $\approx 900^{\circ} \mathrm{C}$. The composition of such powders (e.g., 65 wt. $\% \mathrm{Al}_{2} \mathrm{O}_{3}, 33 \mathrm{wt} \% \mathrm{Al}, 2 \mathrm{wt} . \% \mathrm{NH}_{4} \mathrm{Cl}$ ) provides the packing with metallic $\mathrm{Al}$, alumina as filler material, and $\mathrm{NH}_{4} \mathrm{Cl}$ as activator. The $\mathrm{Al}$ deposited on the substrate surface diffuses into the subsurface regions of the material, where it forms intermetallic phases such as aluminides of $\mathrm{Al}$ or $\mathrm{V}$. Because the substrate materials are heated to temperatures near the annealing range for times sufficient to cause solution processes in the matrix, the materials need a final treatment to optimize the structure. The aluminide layers reach thicknesses of $0.02-0.04 \mathrm{~mm}$, depending on the composition of the substrate materials. The high temperature of the formation process creates layers that develop compressive stresses at lower temperatures; thus, the layers do not contain cracks after preparation is complete. The aluminized layers must be nitrided to obtain electrically insulating coatings.

The aluminizing of $\mathrm{V}$ and its alloys by the "hot dipping" technique covers the substrate materials at $\approx 800^{\circ} \mathrm{C}$ in 1-2 min with a layer of solid. solutions of the substrate metals in $\mathrm{Al}$ or of aluminides of the alloying elements. To obtain good wetting and well-adhered layers, the process requires that surfaces of the structural materials be clean. Adherence can be improved by thermal treatment of the couples at $500-600^{\circ} \mathrm{C}$, but this may result in pores or cavities in the outer part of the aluminide layer, which consists of two parts, the innermost in contact with the substrate by diffusion bonding. The complete layers are $\approx 0.2 \mathrm{~mm}$ thick, and the innermost $\approx 0.12 \mathrm{~mm}$. The aluminide layers must be nitrided to create an insulating surface layer. This process has been successfully used to aluminize austenitic stainless steels and low- and medium-chromium ferritic steels. It is also being applied to aluminize specimens of $\mathrm{V}$ alloy. 9

\section{Gas-Phase Nitridation}

Nitriding experiments were conducted at 650 and $800^{\circ} \mathrm{C}$ in $\mathrm{NH}_{3} / \mathrm{H}_{2}$ gas mixtures on $\mathrm{V}-5 \mathrm{Cr}-5 \mathrm{Ti}$ alloy and Type 316 stainless steel specimens with and without pack-aluminized surfaces. Exposures were conducted in a 
thermogravimetric setup with an electrobalance that had a sensitivity of 0.1 $\mu \mathrm{g}$ and a loading capacity of $2.5 \mathrm{~g}$. The balance was encased in glass, and helium was passed through the assembly countercurrent to the reactive gas, effectively isolating the apparatus from the experimental gas mixture. Test coupons, measuring $10 \times 10 \times 1$ to $2 \mathrm{~mm}$, were prepared by ultrasonically cleaning in alcohol and a spray of acetone prior to insertion into the reaction chamber. The coupons were suspended from the balance by a $200-\mu \mathrm{m}-$ diameter platinum wire and were located in the constant temperature section of the vertical three-zone furnace. Upon completion of exposures, the coupons were sectioned, and both the surfaces and cross sections were analyzed by scanning electron microscopy (SEM) with energy- and wavelength-dispersive spectrometry (EDX and WDS). In addition, surface regions of several specimens were analyzed by Auger electron spectroscopy (AES).

\section{Physical Vapor Deposition}

Physical vapor deposition (PVD) was one method used for the development of AlN coatings on both bare and prealuminized specimens of V-5Cr-5Ti alloy. The coatings were produced by Midwest Research Technologies (MRT) of Wisconsin and by BIRL of Illinois. Coatings were also made by reaction-sputtering in a nitrogen atmosphere at ANL and by ionbeam-assisted reactive evaporation at Cametoid Advanced Technologies, Inc. (CAT), Ontario, Canada. A brief summary of the coating methods is given below and additional details can be obtained from Ref. 1 .

Coatings deposited by MRT. Aluminum nitride was sputtered reactively. That is, an aluminum target was sputtered in a partial pressure of highpurity nitrogen, with argon as the primary sputtering gas. Because the process takes place in a vacuum chamber and uses high-purity reactants, the product should also be very pure. The process takes place at a relatively low temperature, generally not above $\approx 250^{\circ} \mathrm{C}$. The chamber was initially pumped down to $2 \times 10^{-6}$ torr before coating was started. Specimens of both bare and prealuminized $\mathrm{V}-5 \mathrm{Cr}-5 \mathrm{Ti}$ and the $\mathrm{Al}$ target were sputtercleaned for $6 \mathrm{~min}$ with high-purity argon at a flow rate of $45 \mathrm{~cm}^{3} / \mathrm{min}$ and a chamber pressure of 20 mtorr. Subsequently, AlN $\mathrm{X}_{\mathrm{X}}$ was sputter-deposited with a 1200-W RF power source for $10 \mathrm{~h}$ in an argon-nitrogen gas mixture at a chamber pressure of 23 mtorr. The sputtered specimens were cooled in vacuum overnight, and the second side of the specimens was then coated the same way.

Coatings deposited by BIRL. Aluminum nitride coatings were deposited by BIRL, also with reactive sputtering. Specimens of $\mathrm{V}-5 \mathrm{Cr}-5 \mathrm{Ti}$ alloy were used as substrate material and were coated with AlN; some received an 
intermediate layer of TiN and an outer layer of AlN. An MRC 902M sputtering system was used, with partial-pressure control of the reactive gas (nitrogen) and arc suppression on the Al sputtering target. The target was powered by a DC power supply and run at $5 \mathrm{~kW}$. The argon sputtering gas was maintained at a constant 8 mtorr during sputtering. The chamber was initially pumped down to $1 \times 10^{-6}$ torr before coating began. The partial pressure of nitrogen was controlled by an optical gas controller and maintained constant at $1.6 \times 10^{-4}$ torr during coating. The substrate was biased to $150 \mathrm{~V}$ with an Advanced Energy power supply. Coating deposition rate was $1300 \AA / \mathrm{min}$, and maximum temperature during coating was $<200^{\circ} \mathrm{C}$.

Coatings made at ANL. Aluminum nitride coatings were also made at ANL by reaction-sputtering in a low-pressure $\mathrm{N}_{2}$ atmosphere at 350,400 , and $450^{\circ} \mathrm{C}$. The specimens were heated by passing an electrical current through the substrates. The coating thicknesses after $1 \mathrm{~h}$ of deposition were 0.8-1.4 $\mu \mathrm{m}$; after $4 \mathrm{~h}$ of deposition, they were $\approx 5.2 \mu \mathrm{m}$. The coating covered the entire surface of the $V$ alloy specimen, and the layer was found to be fairly hard. The coatings developed at 350 and $450^{\circ} \mathrm{C}$ tended to crack, but that developed at $400^{\circ} \mathrm{C}$ was fairly adherent, mechanically harder, and scratch-resistant.

Coatings made by CAT. Deposition of single-layer and graded AlN coatings on a vanadium substrate using ion-beam assisted reactive evaporation was attempted at CAT. In this process, $\mathrm{Al}$ is evaporated and deposited by either resistive heating or an electron beam source, while the growing film is bombarded with accelerated nitrogen ions produced in an ion gun. A basic advantage of this technique is controllability of the flux (arrival rate) and energy of the ion species independently of the Al deposition rate. In contrast, the voltage, current, chamber pressure, and deposition rate are all interdependent in plasma-based processes. The physical and chemical characteristics of these coatings were presented in an earlier report. Thicknesses of these coatings were 0.5-1.2 $\mu \mathrm{m}$.

\section{Coatings by Chemical Route}

AlN coatings were also deposited by a chemical route using trimethyl aluminum (TMA) and ammonia $\left(\mathrm{NH}_{3}\right)$ as the precursor sources for $\mathrm{Al}$ and $\mathrm{N}$, respectively. Several studies have been reported in the literature on the use of organometallic precursors to form AlN.10-12 Based on these studies, experiments were conducted in BIRL to develop AlN coatings; several sets of experimental conditions were employed and coatings of varying quality and several micrometers in thickness were obtained. 
All reactants and solvents were procured from the Aldrich Chemical Company. Toluene was dried over molecular sieves prior to use. The experimental procedure was as follows: the reaction chamber was flushed with argon gas; $50 \mathrm{~mL}$ of dry toluene was added by syringe through the septum; and $10 \mathrm{~mL}$ of TMA was added, also by syringe, taking care to avoid any exposure of the pyrophoric TMA to the atmosphere. The solution was heated to $74^{\circ} \mathrm{C}$ while slowly purging the system with argon. Ammonia gas was then passed into the system at a rate of $\approx 45 \mathrm{~mL} / \mathrm{min}$ for about $20 \mathrm{~min}$. The reaction of $\mathrm{NH}_{3}$ with TMA at temperatures above $60^{\circ} \mathrm{C}$ proceeds through adduct formation to give a cyclic trimer with a corresponding loss of methane according to the reactions

$$
3 \mathrm{Me}_{3} \mathrm{Al}+3 \mathrm{NH}_{3} \rightarrow 3 \mathrm{Me} 3 \mathrm{Al} \cdot \mathrm{NH}_{3} \rightarrow\left(\mathrm{Me}_{2} \mathrm{Al} \cdot \mathrm{NH}_{2}\right)_{3}+3 \mathrm{CH}_{4} \text {. }
$$

These reactions are exothermic and temperature increases of $20-30^{\circ} \mathrm{C}$ were observed. Completion of the reaction corresponded to cessation of the exotherm. Evaporation of the toluene leaves the trimer as a crystalline white solid that melts to a clear, colorless liquid upon heating to $135^{\circ} \mathrm{C}$. A coupon of $\mathrm{V}$ alloy was immersed in the liquid trimer for $\approx 30 \mathrm{~s}$, raised out of the melt, and heated in steps to drive off methane and convert the intermediate to AlN. Nitrogen was passed through the system, and air was excluded during the heating process and held at $150^{\circ} \mathrm{C}$ for 20 min. During this period, the liquid trimer was converted to a solid, while methane was evolved. Methane evolution continued as the coated coupon was heated to $170^{\circ} \mathrm{C}$ for $25 \mathrm{~min}$, then to $200^{\circ} \mathrm{C}$ for $30 \mathrm{~min}$, and finally to $500^{\circ} \mathrm{C}$ for 24 hours. The coatings were examined by SEM and XRD.

\section{Chemical Vapor Deposition}

Preliminary studies were conducted to evaluate deposition of AlN by CVD, an approach that has been well demonstrated for developing very thin electrical insulator coatings for semiconductor applications. The advantage of CVD is that the coating will be applied from a gas-phase reaction rather by line of sight in the PVD method, and as a result can be adopted to coat components with complex shapes. Because CVD requires fairly high temperatures $\left(800-900^{\circ} \mathrm{C}\right)$, one must establish whether AlN can be deposited by CVD without degrading the properties of the substrate. To address this question, coupon specimens of $\mathrm{V}-5 \mathrm{Cr}-5 \mathrm{Ti}$ were coated at BIRL through a combination of thermal and plasma-assisted processing at 600 $800^{\circ} \mathrm{C}$. 


\section{Li Test Facility}

Two static liquid-metal systems were designed and fabricated for studies on compatibility of structural materials and insulator coatings in liquid metals. Figure 4 is a photograph of the experimental systems. Each system was filled with $\approx 15 \mathrm{~L}$ of high-purity $\mathrm{Li}$, the chemical composition of which is listed in Table 1. During the initial period of $\approx 3000 \mathrm{~h}$, the two Li systems (identified as vessels $\# 2$ and 3 ) were operated at 350 and $400^{\circ} \mathrm{C}$, respectively. Subsequently, the temperatures of both systems were set at $300^{\circ} \mathrm{C}$ to examine the compatibility of insulator coatings, in support of the proposed MHD test with an insulated test section to be conducted at a maximum temperature of $300^{\circ} \mathrm{C}$. In one of the $\mathrm{Li}$ systems (identified as vessel \#3), $\mathrm{N}_{2}$ gas was bubbled through a small tube immersed in $\mathrm{Li}$ to increase $\mathrm{N}$ concentration in the $\mathrm{Li}$.

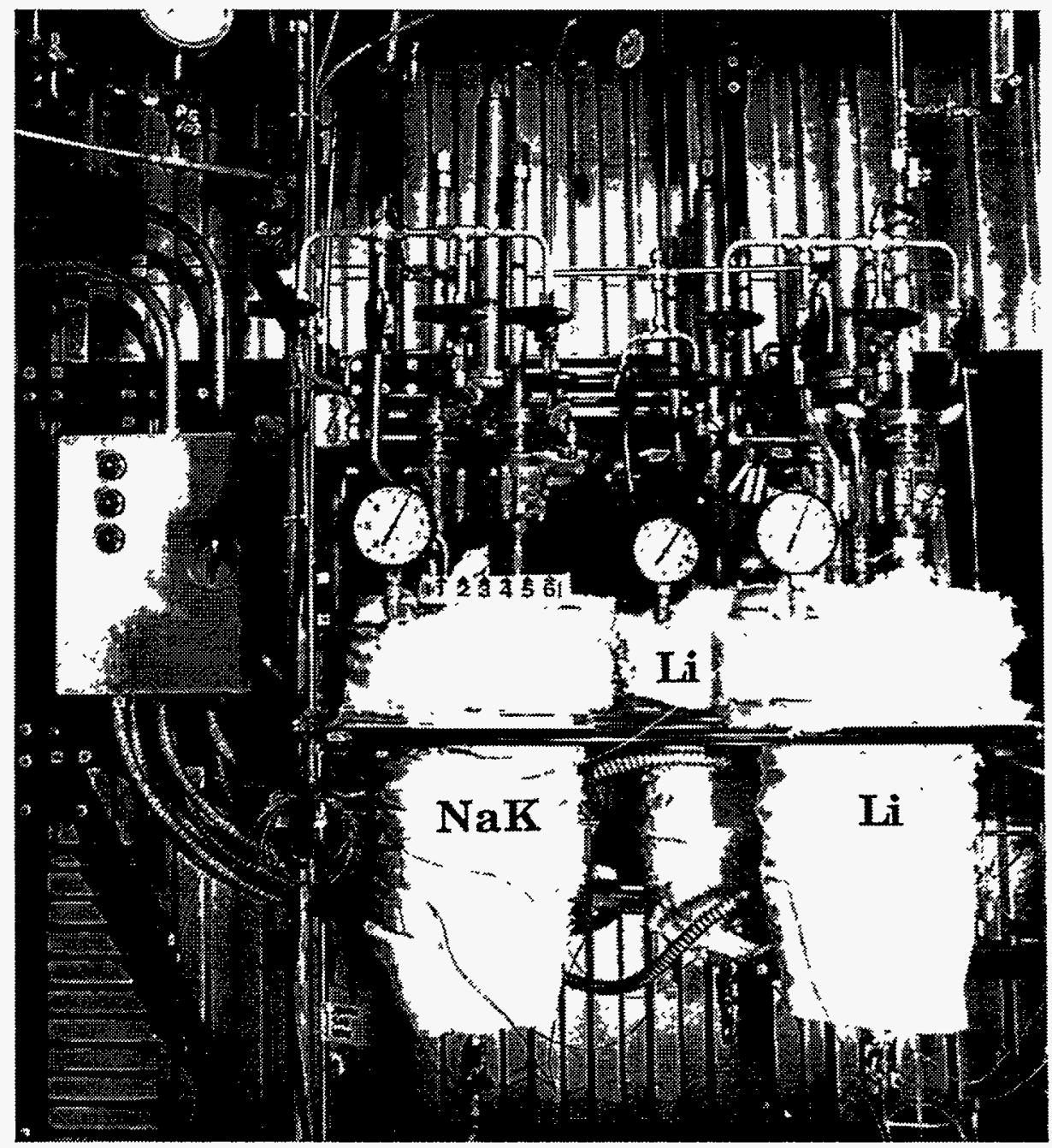

Fig. 4. Li systems used in present study 
Table 1. Chemical composition of lithium

\begin{tabular}{cc}
\hline Element & Composition \\
\hline $\mathrm{Li}$ & $99.97 \%$ \\
$\mathrm{Na}$ & $50 \mathrm{ppm}$ \\
$\mathrm{Ca}$ & $50 \mathrm{ppm}$ \\
$\mathrm{K}$ & $40 \mathrm{ppm}$ \\
$\mathrm{Fe}$ & $5 \mathrm{ppm}$ \\
$\mathrm{Si}$ & $10 \mathrm{ppm}$ \\
$\mathrm{Cl}$ & $10 \mathrm{ppm}$ \\
$\mathrm{N}$ & $80 \mathrm{ppm}$ \\
\hline
\end{tabular}

Coupon specimens of $\mathrm{V}-5 \mathrm{Cr}-5 \mathrm{Ti}$ alloy, Type 316 stainless steel in bare and prealuminized conditions, and AlN-deposited samples from several sources (discussed above) were exposed in the liquid-metal systems. Weight change was measured to establish the corrosion rates for the structural alloys and coatings as a function of temperature, time, and liquid metal chemistry. After exposures, the specimens were examined by SEM with EDX and by XRD. The coated specimens were examined to evaluate coating integrity after liquid metal exposure, microstructural changes in coatings, coating/substrate interactions, and electrical insulation characteristics of the coatings.

\section{RESULTS AND DISCUSSION}

\section{Samples Nitrided in Gas Phase}

To evaluate the potential of developing insulator coatings, preliminary gas-phase nitridation experiments were conducted with Type 316 stainless steel and $\mathrm{V}-5 \mathrm{Cr}-5 \mathrm{Ti}$ alloy with and without aluminized surface layers in a 4 vol. $\% \mathrm{NH}_{3}-\mathrm{H}_{2}$ gas mixture at temperatures between 600 and $800^{\circ} \mathrm{C}$. Figure 5 is a plot of the square of weight change versus exposure time for the Type 316 stainless steel nitrided at $800^{\circ} \mathrm{C}$. Figure 6 is a plot of the square of weight change versus exposure time for the $\mathrm{V}-5 \mathrm{Cr}-5 \mathrm{Ti}$ alloy nitrided at 600 and $800^{\circ} \mathrm{C}$. The straight lines in Figs. 5 and 6 indicate that the nitridation process follows a parabolic rate expression for both alloys. The parabolic rate constant for nitridation of Type 316 stainless steel at $800^{\circ} \mathrm{C}$ is $1.6 \mathrm{x}$ $10^{-4} \mathrm{mg}^{2} \mathrm{~cm}^{-4} \mathrm{~s}^{-1}$ and those for nitridation of $\mathrm{V}$ alloy are $9.1 \times 10^{-6}$ and $6.9 \mathrm{x}$ $10^{-7} \mathrm{mg}^{2} \mathrm{~cm}^{-4} \mathrm{~s}^{-1}$ at 800 and $600^{\circ} \mathrm{C}$, respectively.

A detailed examination of the surfaces and cross sections of nitrided specimens of Type 316 stainless steel showed ( $\mathrm{Fe}, \mathrm{Cr}$ ) nitrides, while those of $\mathrm{V}$ alloy showed V-rich nitrides. Figure 7 shows the AES spectra of the 
surfaces of Type 316 stainless steel and V-5Cr-5Ti alloy nitrided at $800^{\circ} \mathrm{C}$. Figure 8 shows concentration profiles as a function of depth for $\mathrm{Fe}, \mathrm{Cr}, \mathrm{Ni}$, and $\mathrm{N}$ in a nitrided sample of Type 316 stainless steel. The specimen displayed nitrogen enrichment to a depth of $40 \mu \mathrm{m}$ and consisted of predominantly $(\mathrm{Fe}, \mathrm{Cr})$ nitrides. Figure 9 shows concentration profiles as a function of specimen depth for $\mathrm{V}, \mathrm{Cr}, \mathrm{Ti}, \mathrm{O}$, and $\mathrm{N}$, analyzed using AES. The bottom figure is an expanded version of the depth profiles for $\mathrm{Cr}, \mathrm{Ti}$, and $\mathrm{S}$ shown in the top figure. The results indicate that $\mathrm{N}$ enrichment via gasphase nitridation is possible but that an exclusive binary nitride layer of $\mathrm{V}$ was not observed.

Figure 10 is a plot of the square of weight change versus exposure time for the aluminized $\mathrm{V}-5 \mathrm{Cr}-5 \mathrm{Ti}$ alloy nitrided at $650^{\circ} \mathrm{C}$. The rate constant of $2.2 \times 10^{-8} \mathrm{mg}^{2} \mathrm{~cm}^{-4} \mathrm{~s}^{-1}$ for the aluminized alloy is lower than that for nitridation of the bare alloy, but the surface and subsurface regions consisted predominantly of V-rich nitride.

The nitrided scales were more adherent on Type 316 stainless steel than on either the bare or the prealuminized V alloy. The possible explanation is the segregation of sulfur in the surface regions of the scale in the $\mathrm{V}$ alloy, which can lead to debonding and spallation of the scales, similar to those observed in oxidation studies. Another difference between the nitriding of Type 316 stainless steel and $\mathrm{V}$ alloy is the enrichment of oxygen in the surface regions in the $\mathrm{V}$ alloy. It is evident that the scavenging effect of $\mathrm{V}$ and $\mathrm{Ti}$ for $\mathrm{O}$ requires the oxygen partial pressure in the exposure environment to be significantly lower for $V$ alloy than for Type 316 stainless steel to minimize the $O$ ingress into the alloy. Calculations made on the thermodynamic stability of several oxides shown in Fig. 11 indicate that the oxygen partial pressures should be less than $10^{-40}$ atm at $650^{\circ} \mathrm{C}$ to prevent formation of the $\mathrm{VgO}$ phase. The pressures needed for preventing oxides of $\mathrm{Ti}$ and $\mathrm{Al}$ are even lower by a few orders of magnitude. Such low oxygen partial pressures will be difficult to achieve in experiments that involve flowing gas, even if the gases are purified by hot gettering.

Another consideration for the formation of a pure binary nitride such as AlN is that the required partial pressures of nitrogen in the exposure environment are extremely low. Figure 12 shows the stability of several nitride phases as a function of $\mathrm{N}$ activity depicted in terms of $\mathrm{NH}_{3}$ and $\mathrm{H}_{2}$ partial pressures (components of gas mixtures used in nitridation experiments) and temperature. Also indicated by dashed lines in the figure are the nitrogen activities that correspond to 100,500 , and $1000 \mathrm{wtppm} \mathrm{N}$ in $\mathrm{Li}$. The calculated curves indicate that to obtain AlN phase by gas-phase nitridation, the ratio $\left(\mathrm{NH}_{3} / \mathrm{H}_{2}{ }^{3 / 2}\right)$ must be less than $10^{-18}$ and $10^{-12}$ at 800 and $400^{\circ} \mathrm{C}$. Such low values cannot be maintained experimentally because even with a $\mathrm{H}_{2}-\mathrm{NH}_{3}$ gas mixture containing $1 \mathrm{vppm} \mathrm{NH3}$ can only result in a value of $\approx 10^{-6}$ for the ratio. Based on the experimental data developed with gas-phase reactions and on the analysis of data, it is concluded that gas- 
phase nitridation is not a viable method for developing electrically insulating AIN coatings.

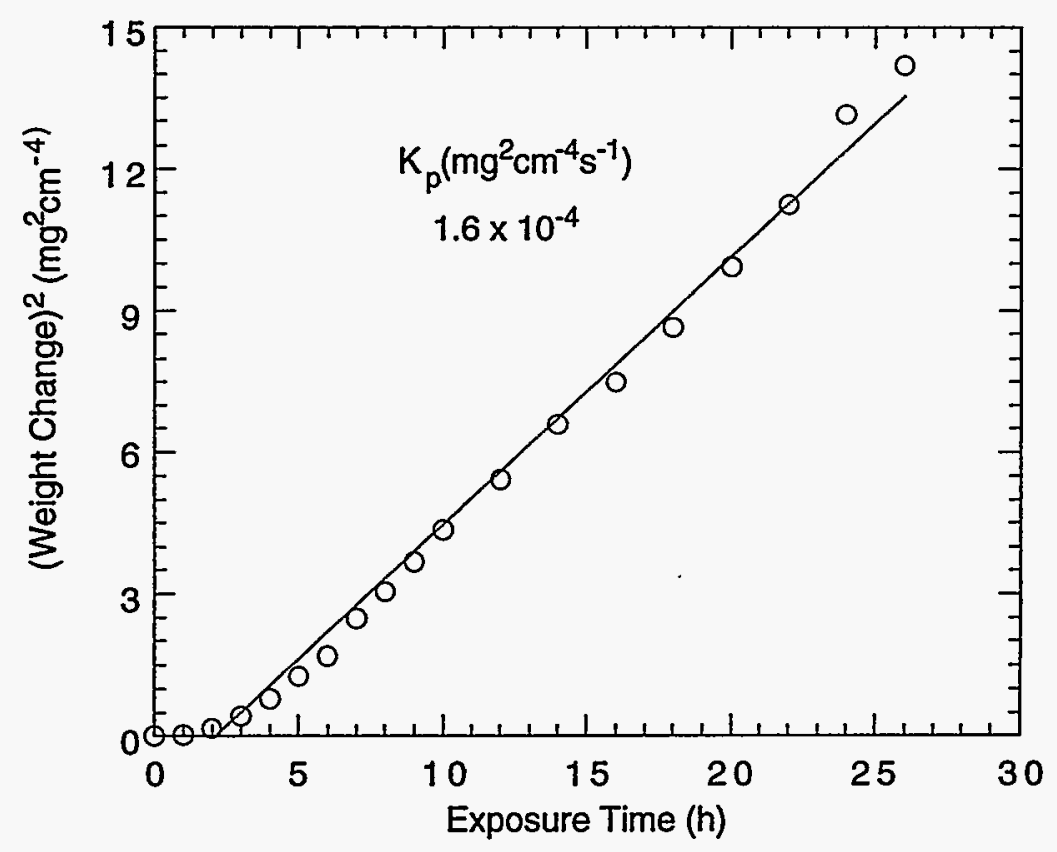

Fig. 5. Plot of weight change squared vs. exposure time for Type 316 stainless steel nitrided at $800^{\circ} \mathrm{C}$

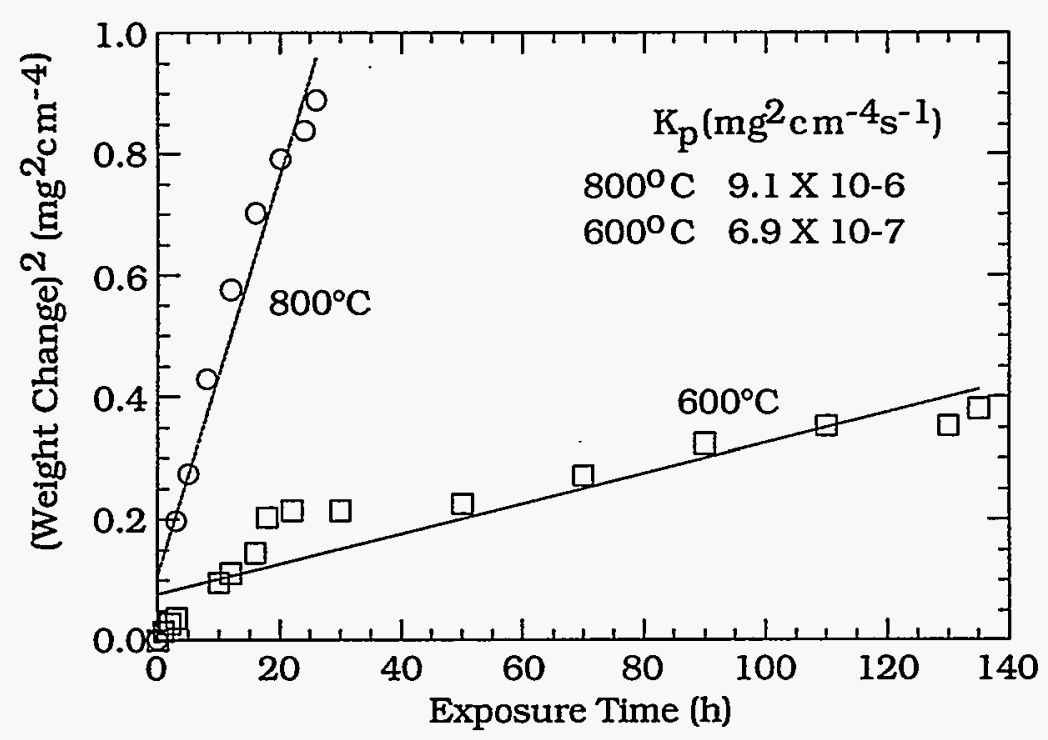

Fig. 6. Plot of weight change squared vs. exposure time for $\mathrm{V}-5 \mathrm{Cr}-5 \mathrm{Ti}$ alloy nitrided at 600 and $800^{\circ} \mathrm{C}$ 

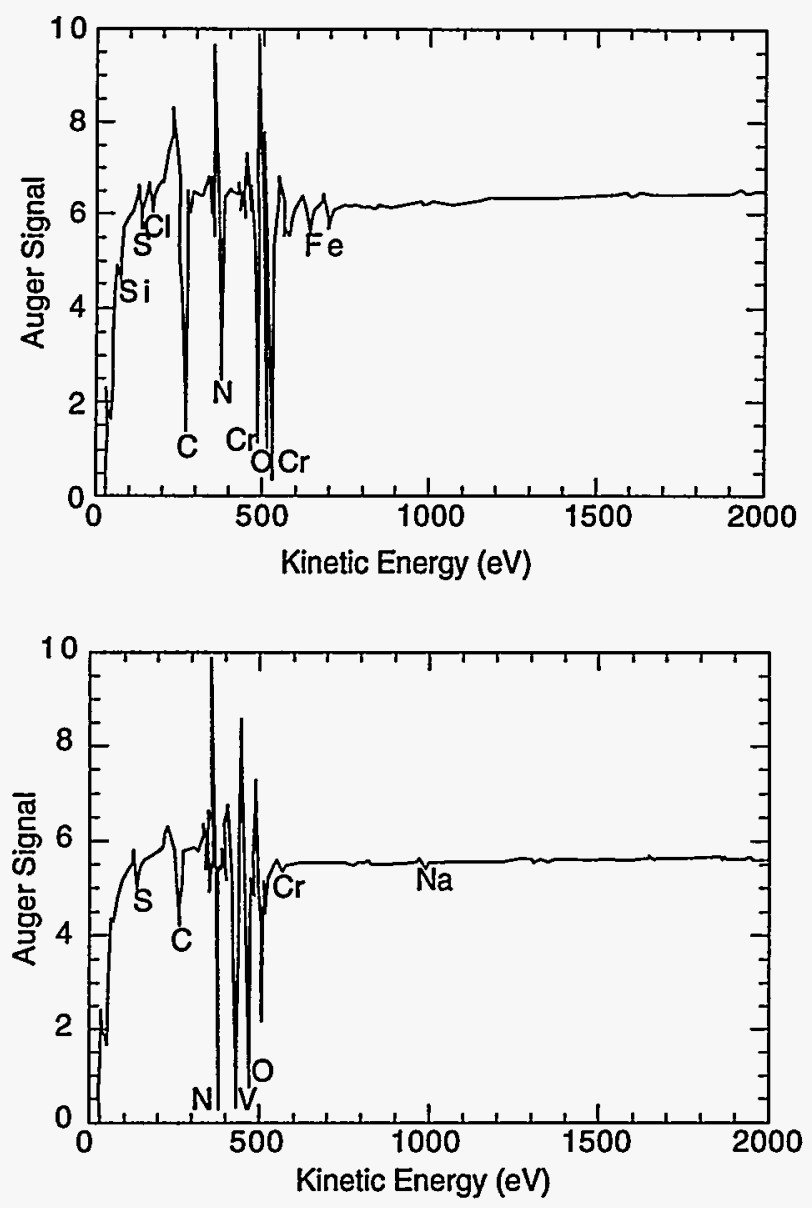

Fig. 7. AES spectra for Type 316 stainless steel (top) and V-5Cr-5Ti alloy (bottom), nitrided at $800^{\circ} \mathrm{C}$

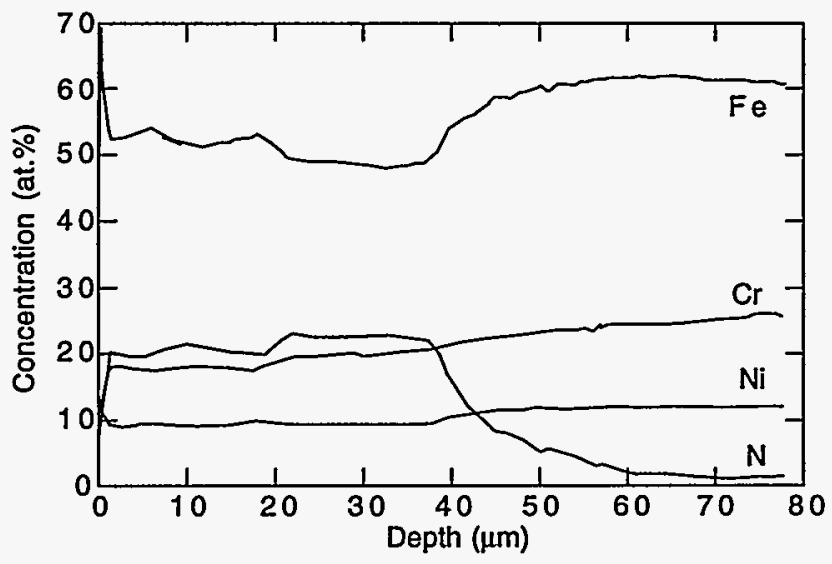

Fig. 8. AES depth profiles for elements Fe, $\mathrm{Cr}, \mathrm{Ni}$, and $\mathrm{N}$ for Type 316 stainless steel nitrided at $800^{\circ} \mathrm{C}$ 

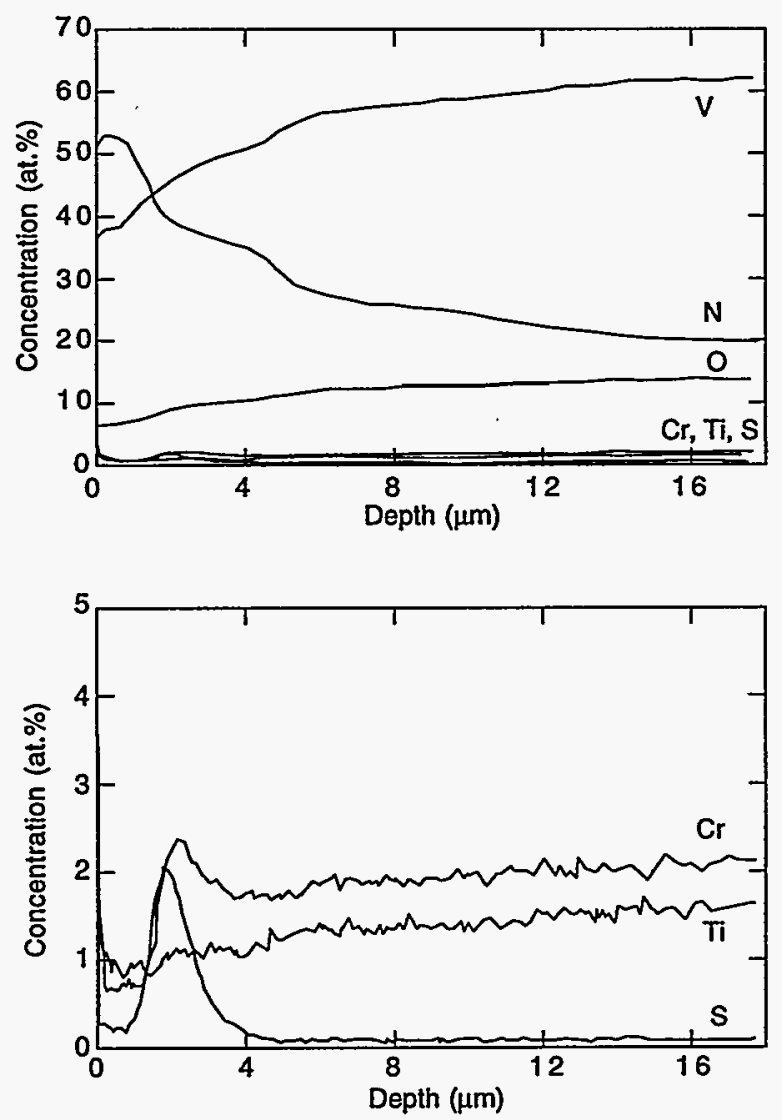

Fig. 9. AES depth profiles for $\mathrm{V}-5 \mathrm{Cr}-5 \mathrm{Ti}$ specimen nitrided at $800^{\circ} \mathrm{C}$. Bottom figure is expanded version for $\mathrm{Cr}, \mathrm{Ti}$, and $\mathrm{S}$ shown in top figure.

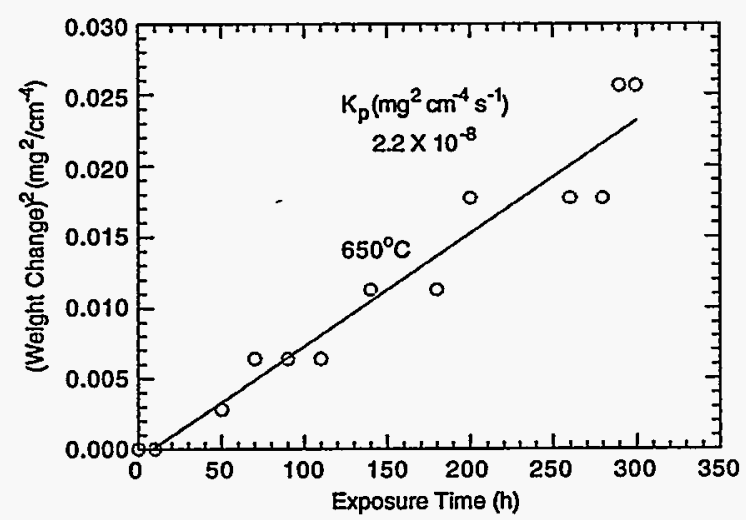

Fig. 10. Plot of weight change squared vs. exposure time for aluminized $\mathrm{V}-5 \mathrm{Cr}$ $5 \mathrm{Ti}$ alloy nitrided at $650^{\circ} \mathrm{C}$ 


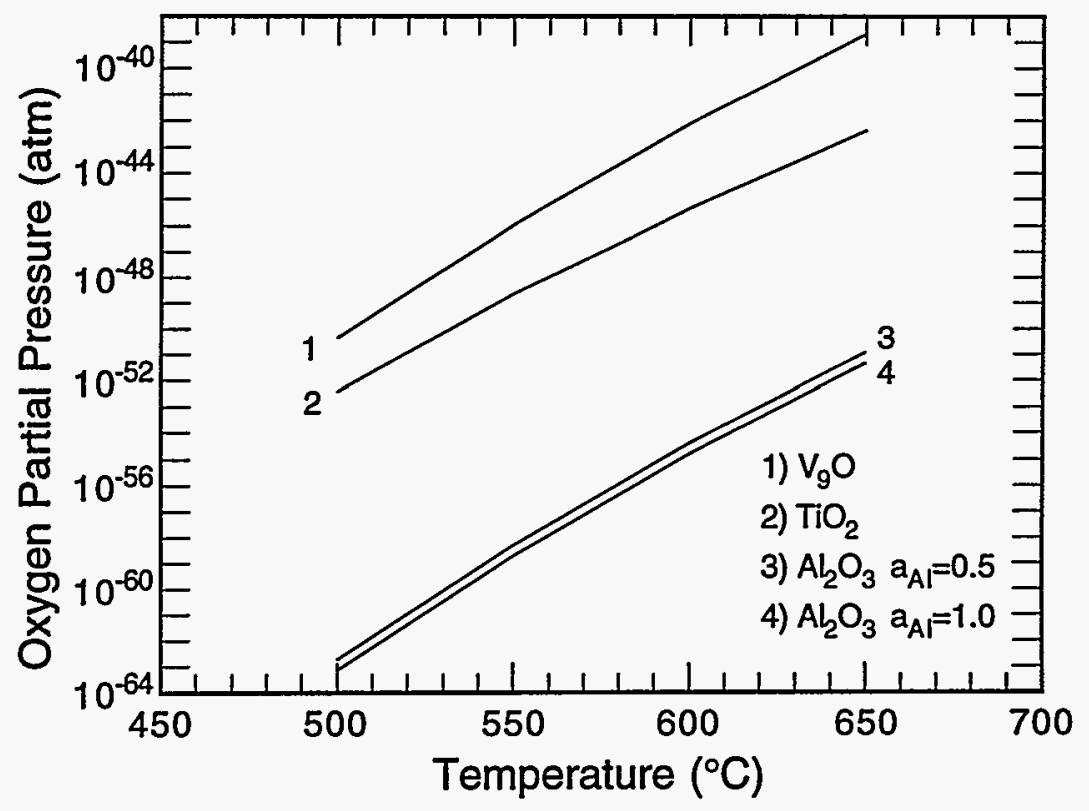

Fig. 11. Stability of oxide phases as a function of temperature and oxygen partial pressure

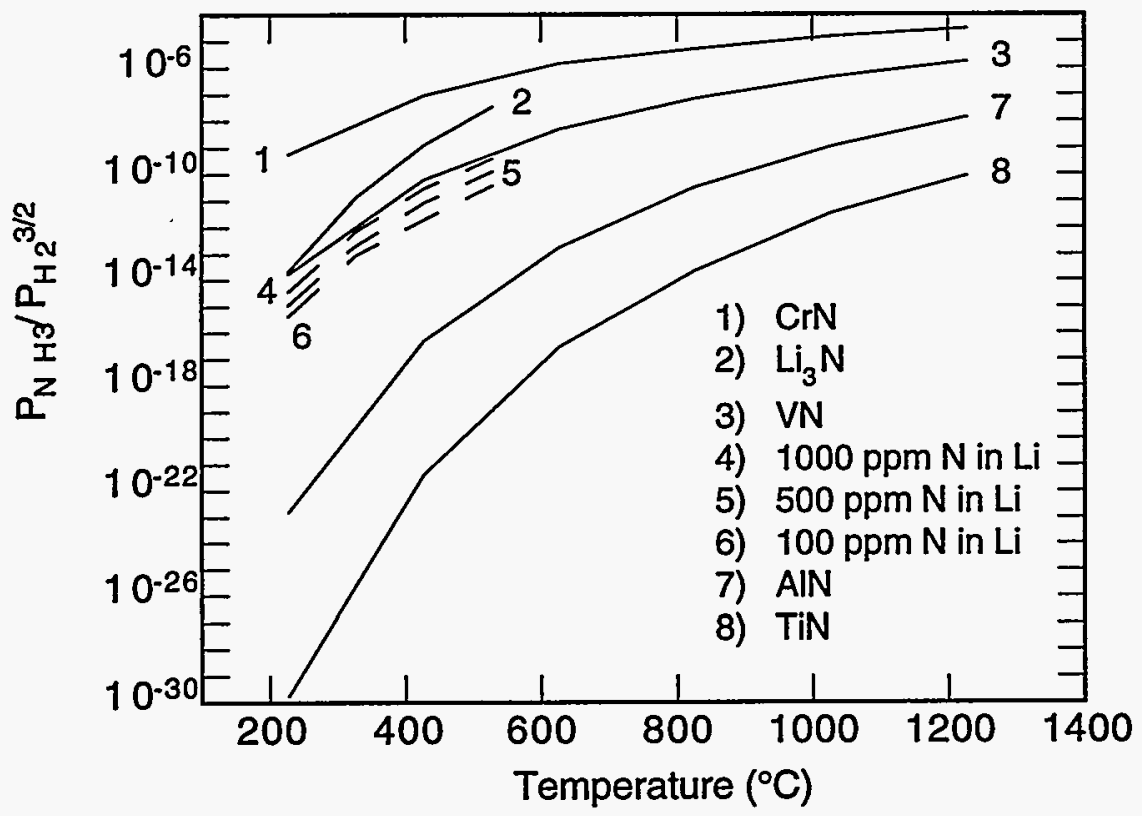

Fig. 12. Stability of several nitride phases as a function of temperature and nitrogen pressure depicted in terms of $\mathrm{NH}_{3}$ and $\mathrm{H}_{2}$ partial pressures. Also shown are curves (dashed lines) corresponding to 100,500 , and 1000 wtppm $\mathrm{N}$ in $\mathrm{Li}$ 


\section{Characteristics of As-Coated Specimens}

\section{Physical Vapor Deposition}

Figure 13 shows SEM photomicrographs of MRT-deposited AlN-coated $\mathrm{V}$-alloy specimens in the as-deposited condition. The AlN layers were fairly compact and of uniform thickness in the range 8-12 $\mu \mathrm{m}$. X-ray diffraction analysis showed hexagonal AlN phase with a (002) orientation. 1 No vanadium nitride was detected because the substrate was at $<200^{\circ} \mathrm{C}$ during the coating process. Even though the coatings were fairly adherent, early exposures of these coated specimens in $\mathrm{Li}$ resulted in complete disappearance of the coating layer by either spallation or dissolution. As a result, the coated specimens were given a thermal hardening treatment at $700-900^{\circ} \mathrm{C}$ prior to exposure in Li. Figure 14 shows SEM photomicrographs of AlN-coated V-alloy specimens after the hardening treatment at $900^{\circ} \mathrm{C}$ for $110 \mathrm{~h}$. Figures $14 \mathrm{a}$ and $14 \mathrm{~b}$ show the hardened MRT-deposited layers on bare and prealuminized V-alloy substrate. X-ray diffraction analysis of these heat-treated specimens also showed hexagonal AlN phase with (002) orientation, but traces of the $\mathrm{V}_{2} \mathrm{~N}$ phase were noted because of a reaction between AlN and V at the coating/substrate interface. Figures $14 \mathrm{c}$ and $14 \mathrm{~d}$ show the hardened BIRL-deposited coatings on bare V-alloy substrate. The specimen in 14c had an intermediate layer of TiN, sputter-deposited to minimize possible reaction between AlN and $\mathrm{Ti}$ in the alloy.

Figure 15 shows SEM photomicrographs of ANL-deposited AlN-coated $\mathrm{V}$-alloy specimens in the as-deposited condition, and EDX analysis of the coating layer. The figure shows that reaction sputtering with the substrate at a higher temperature seems to follow the substrate surface morphology, e.g., polishing lines and surface defects. X-ray diffraction data for these specimens also indicated the coatings to be hexagonal AlN with (002) preferred orientation.

\section{Chemical Vapor Deposition}

Very few samples were coated by CVD technique because the primary purpose of the effort was to evaluate the feasibility of the approach rather than to make dense, thick coatings. In general, the coatings prepared by CVD were fairly thin and exhibited significant cracking. Figure 16 is an SEM photomicrograph of the surface of a coated specimen. X-ray diffraction analysis of the coated specimen showed some weak lines of AlN, but the specimen was not examined further. Because the coatings had significant cracking, electrical resistivity measurements were not made on these coated samples, nor were the samples used in $\mathrm{Li}$ exposure experiments. The preliminary results for the CVD approach showed that the probability of 

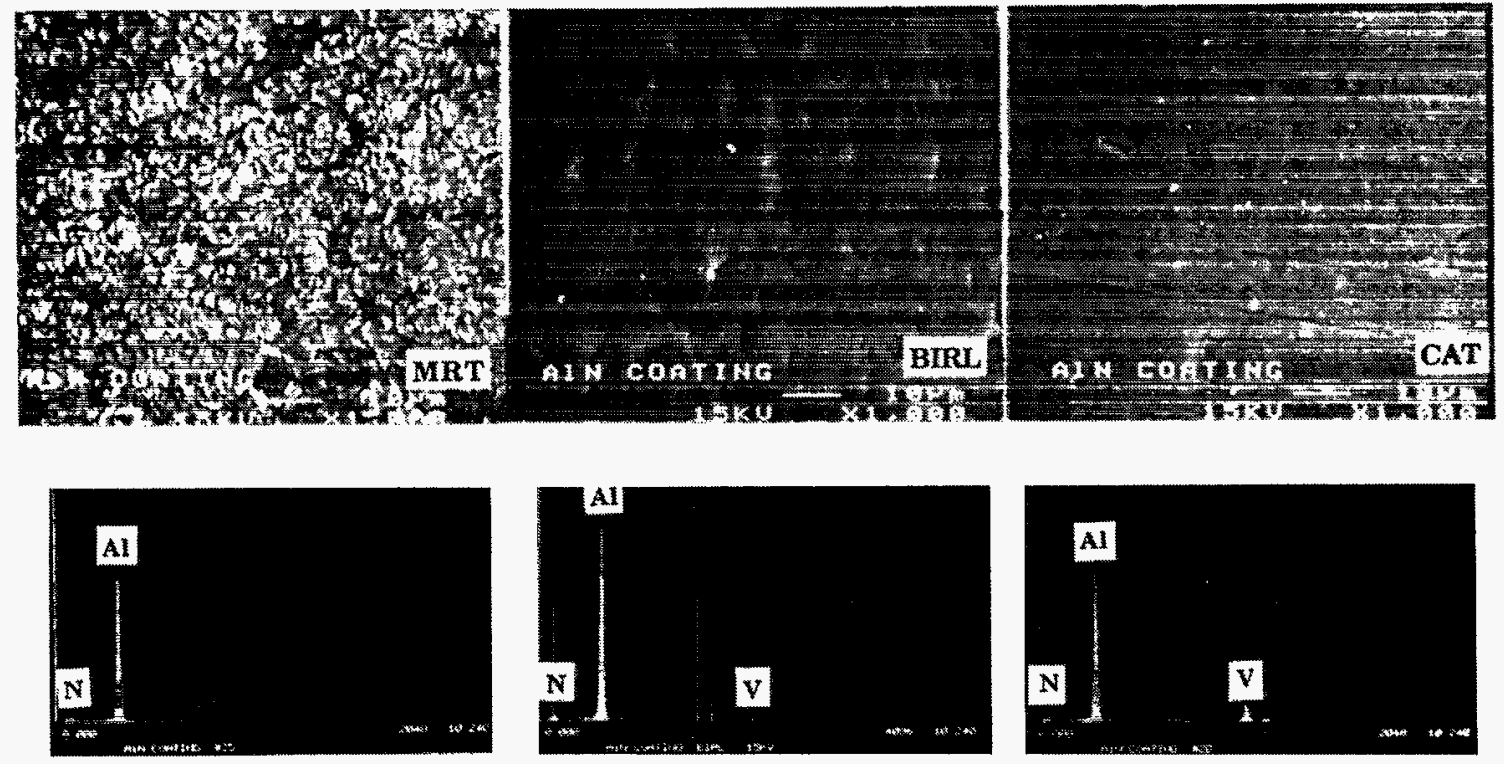

Fig. 13. SEM photomicrographs and EDX analysis of MRT- and BIRL- and CAT-deposited AlN coating on V-alloy specimens in as-deposited condition
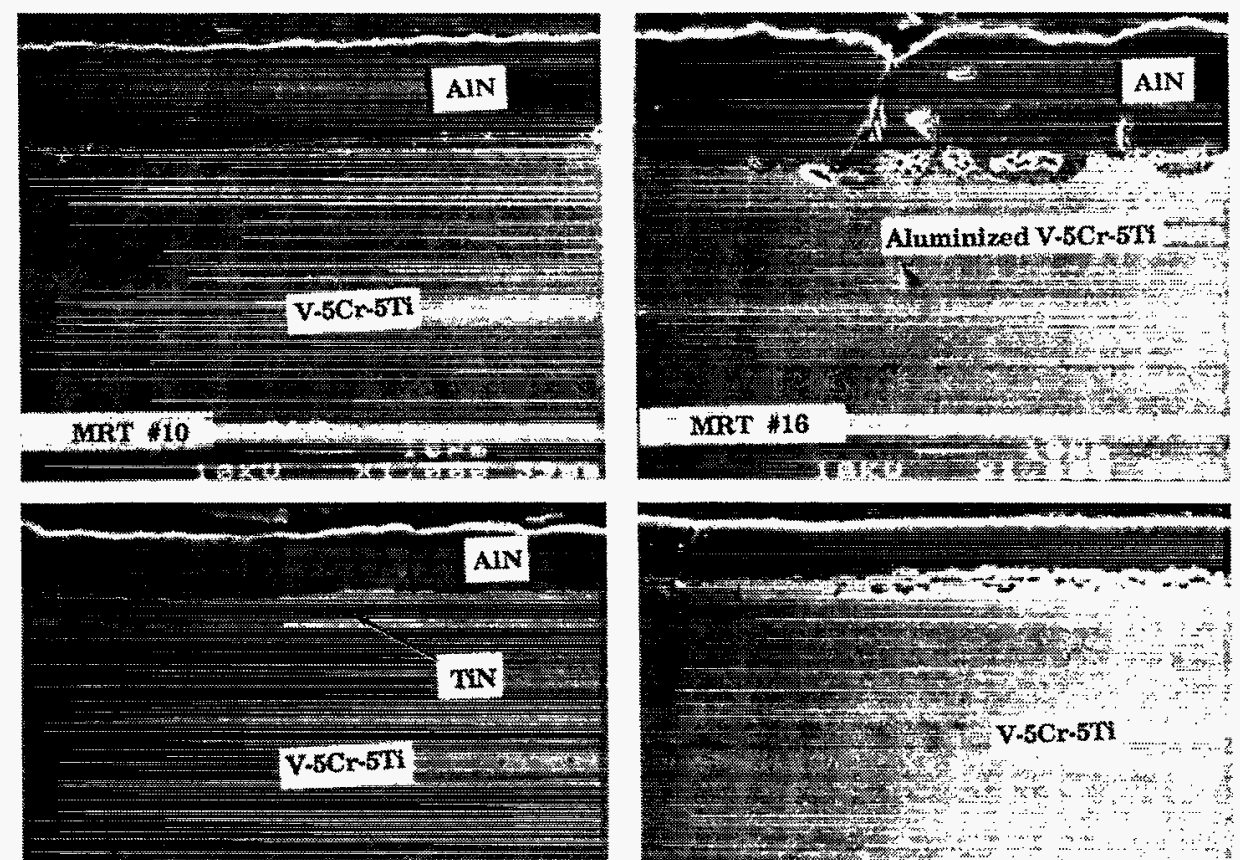

BIRL $\# 54$
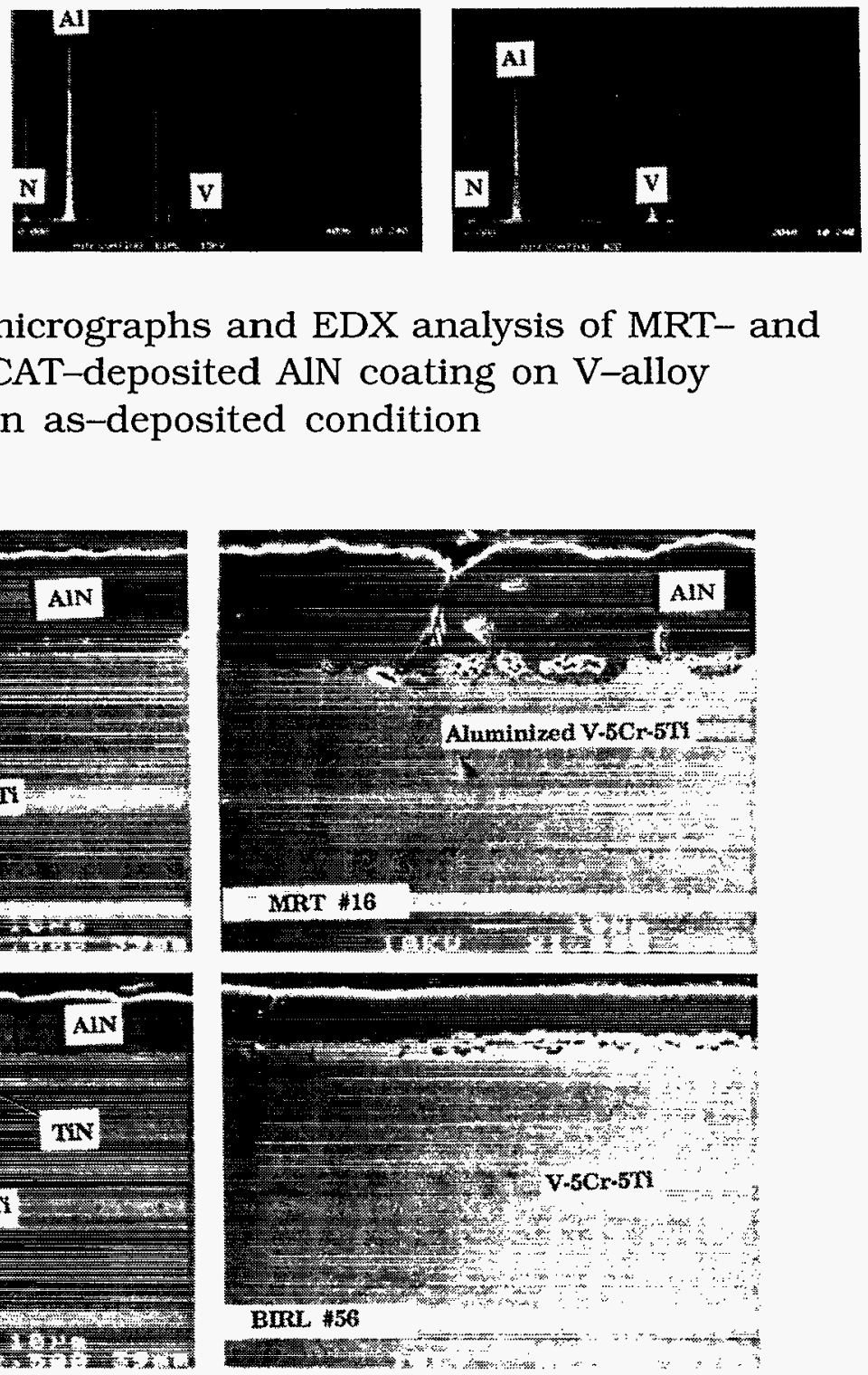

Fig. 14. SEM photomicrographs of AlN-coated V-alloy specimens after hardening treatment at $900^{\circ} \mathrm{C}$ for $110 \mathrm{~h}$ 

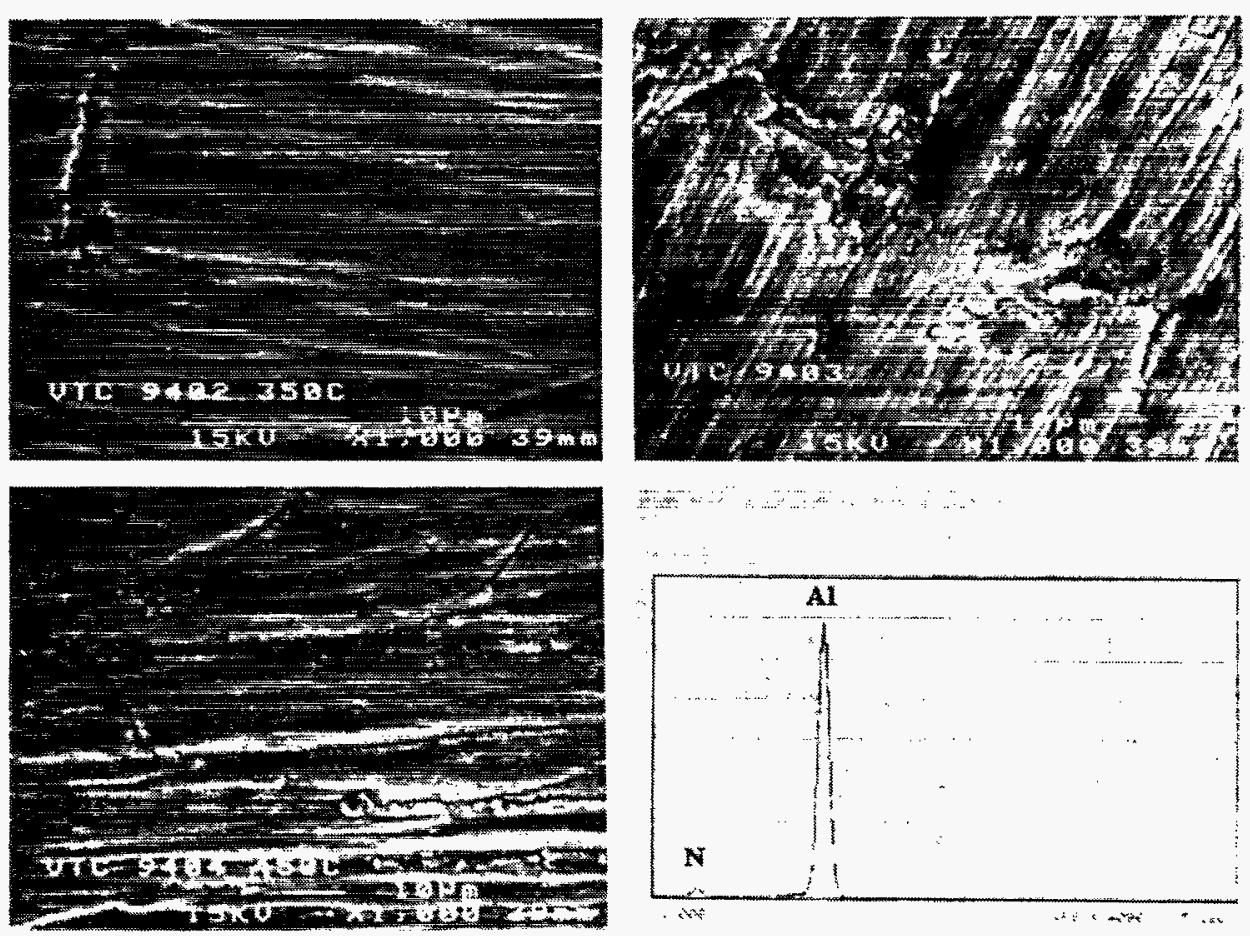

Fig. 15. SEM photomicrographs of ANL-deposited AlN coated V-alloy specimens in as-deposited condition and EDX analysis of coating layer

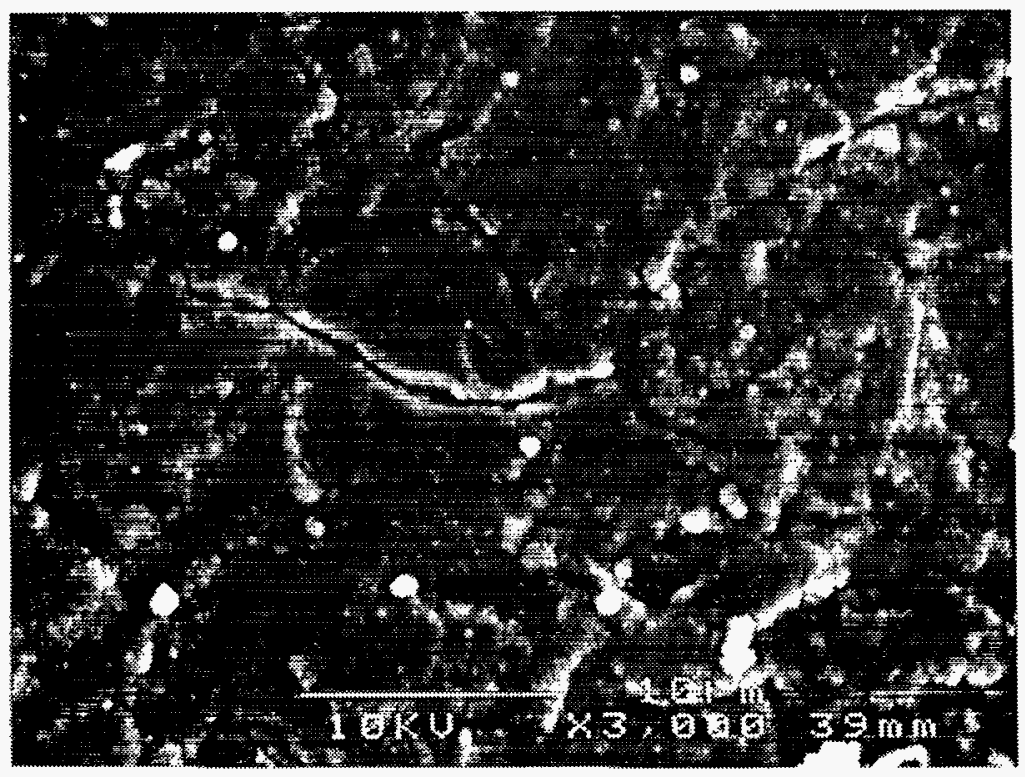

Fig. 16. SEM photomicrograph of AIN surface coated by CVD 
producing good coatings is quite high, but significant additional work is needed to experiment with the coating parameters and to develop dense, adherent coatings.

\section{Coatings by Chemical Route}

Even though the chemical route was used following the general procedure described earlier, several runs were conducted to examine the role of different coating parameters on coating integrity. In some experiments, coupons were immersed in just enough liquid cyclic trimer precursor to cover the coupon surface, and the entire mass was then heated to convert the precursor to a solid. This procedure produced thick coatings (see Fig. 17), but they were heavily cracked and weakly adhered to the substrate. In another experiment, a coupon was immersed briefly in the molten precursor, removed, and heated to convert the film of precursor to a coating of AlN. Formation of AlN was confirmed and, in most cases, the coatings were optically transparent. While severe cracking was observed in thick coatings, the thin coatings appeared to be crack-free. Figure 18 shows the pronounced effect of thickness on cracking. The original groove near the substrate hole, which was drilled to enable raising and lowering the sample, shows a pattern of alternatively cracked (thick) and crack-free (thin) deposits. Cracking was also observed at spots on some samples, presumably due to foreign material or to premature decomposition of the liquid precursor that resulted in solid specks before the liquid drained uniformly from the coupon surface. This is shown in Fig. 19.

In an attempt to determine the cause of cracking, two coating runs were prematurely arrested after a brief low temperature $\left(200^{\circ} \mathrm{C}\right)$ annealing that should have driven off most of the methane byproduct. The coatings were cracked at this stage, proving that the cracking occurs fairly early in the pyrolysis. The cause of cracking may be due to shrinking of the coatings as the composition changes toward AlN, or it may be due to methane evolution within the thicker coatings.

EDX analysis showed the presence of $\mathrm{Al}$ with very small amounts of $\mathrm{Si}$ (perhaps from the Pyrex glassware), along with peaks corresponding to the constituents of the substrate. Based on the runs conducted, it appears that coating thickness varied with the temperature of the melt. Coatings applied at $9^{\circ} \mathrm{C}$ above the melting temperature of $134^{\circ} \mathrm{C}$ were thin and mostly crackfree. X-ray diffraction patterns of the coated coupons showed peaks corresponding to the substrate alloy and several weak peaks that match the $\mathrm{X}$-ray pattern of hexagonal AlN. The chemical approach requires significant additional effort to obtain crack-free, fairly thick $(10-20 \mu \mathrm{m})$ AlN coatings. 


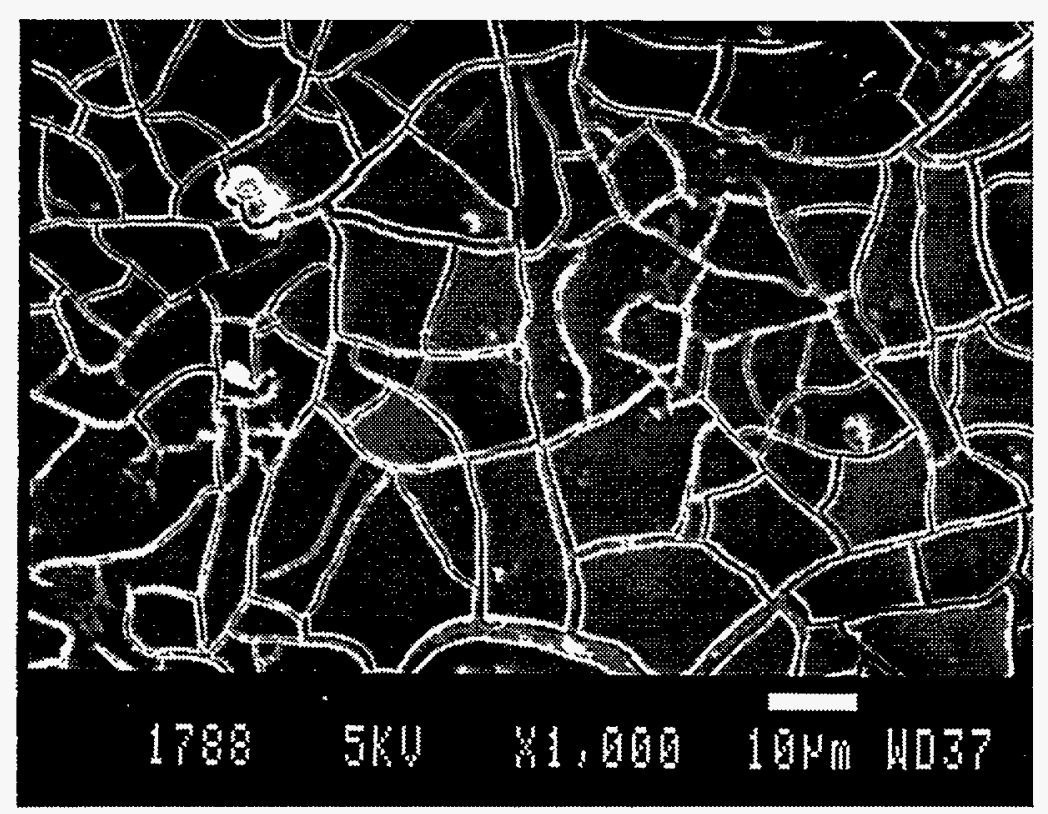

Fig. 17. SEM photomicrograph of AlN coating developed by chemical route

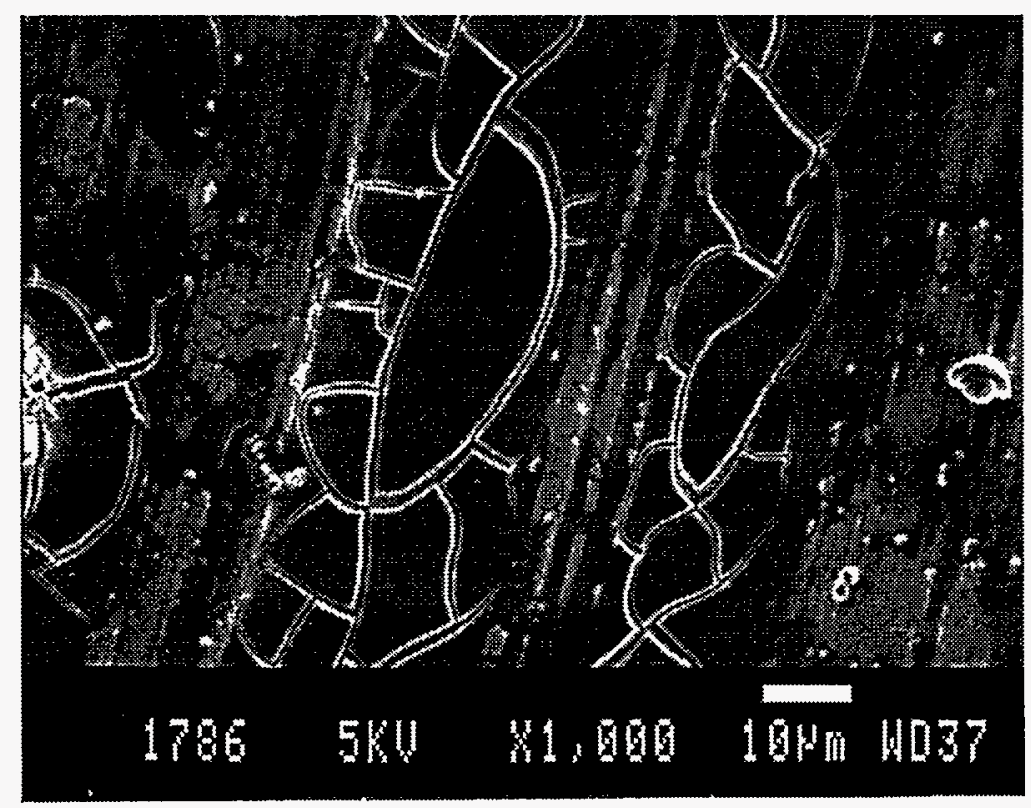

Fig. 18. SEM photomicrograph of AlN coating showing pronounced effect of thickness on cracking 


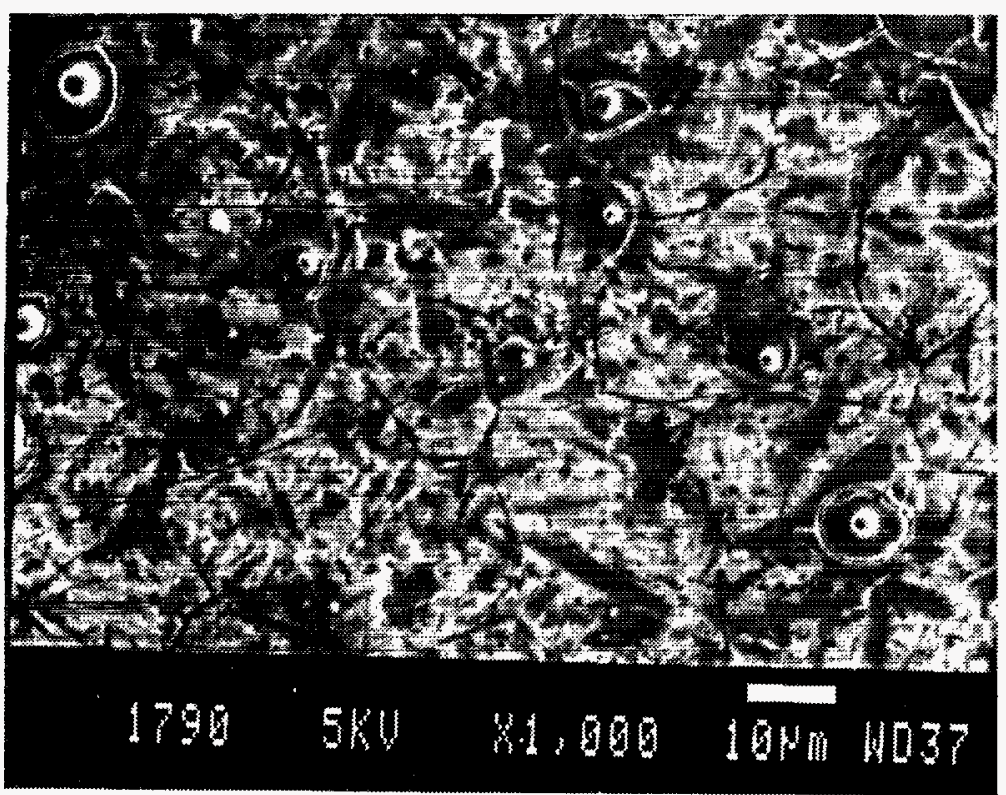

Fig. 19. SEM photomicrograph of AlN coating which shows cracks arising from premature decomposition of liquid precursor

\section{Electrical Insulating Behavior of As-Coated Coatings}

For the coatings to be viable in a fusion reactor, the electrical resistance of the coatings must be sufficiently high not only in the as-coated condition but also after exposure to a liquid $\mathrm{Li}$ environment and to irradiation, as well as when subjected to thermal cycling in service. Because only the PVD technique yielded adherent, crack-free AlN coatings, the electrical resistance of several of these coated specimens was measured at ANL by the approach described earlier. ${ }^{1}$ Coating resistance was characterized at different locations on each sample to examine the electrical integrity of the coating and to identify the types and location(s) of defects.

Figure 20 shows measured values of electrical resistance at several locations on bare and prealuminized specimens in as-coated condition and after a hardening treatment. The figure shows that coated specimens \#36, \#10, and \#16 obtained from MRT have resistances at most locations that are orders of magnitude higher than needed for blanket application.

\section{Lithium Compatibility of Coatings}

Lithium compatibility tests were conducted primarily with specimens that were PVD-coated with AlN. The coatings developed by other techniques were neither crack-free nor of adequate mechanical integrity for 
exposure in $\mathrm{Li}$. AlN-coated specimens from several of the sources described above were exposed to two different $\mathrm{Li}$ environments, characterized by normal purity and containing higher $\mathrm{N}$ obtained by bubbling $\mathrm{N}_{2}-\mathrm{Ar}$ gas mixture into Li. A listing of experiments performed in $\mathrm{Li}$ of normal purity is given in Table 2 with details on the objectives of different exposure runs, exposure times and temperatures, specimens exposed, and results obtained. A similar listing of experiments performed in Li with higher activities of $\mathrm{N}$ and/or $\mathrm{Al}$ is given in Table 3.

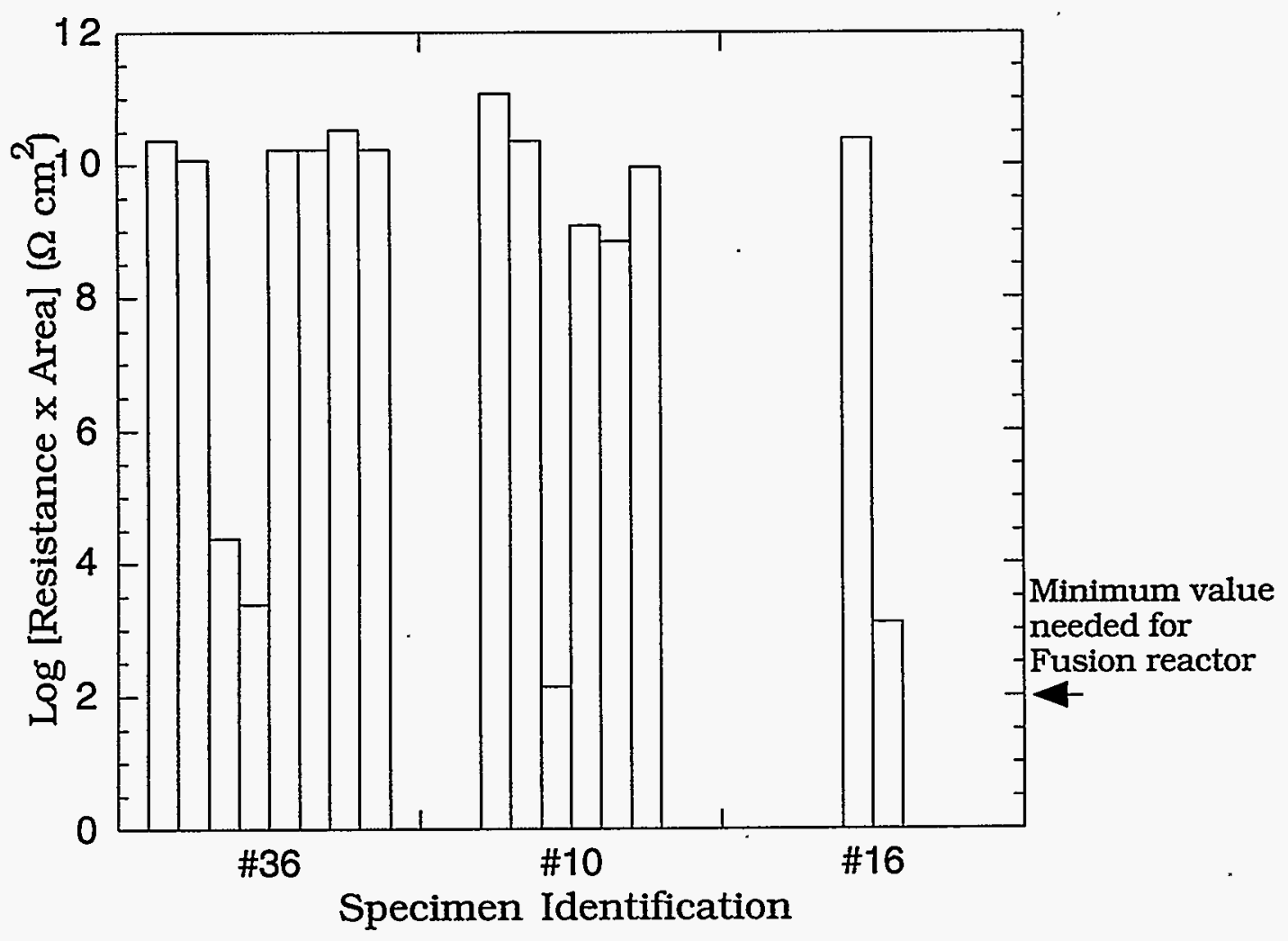

Key for Specimen Treatment

\#36: V-5Cr-5Ti alloy, AlN coated

\#10: Alloy, AlN coated, hardened for $110 \mathrm{~h}$ at $900^{\circ} \mathrm{C}$

\#16: Alloy, prealuminized, AlN coated, hardened for $110 \mathrm{~h}$ at $900^{\circ} \mathrm{C}$

Fig. 20. Electrical resistance data for AlN-coated specimens in as-coated and hardened conditions 
Table 2. Experiments performed in lithium of normal purity

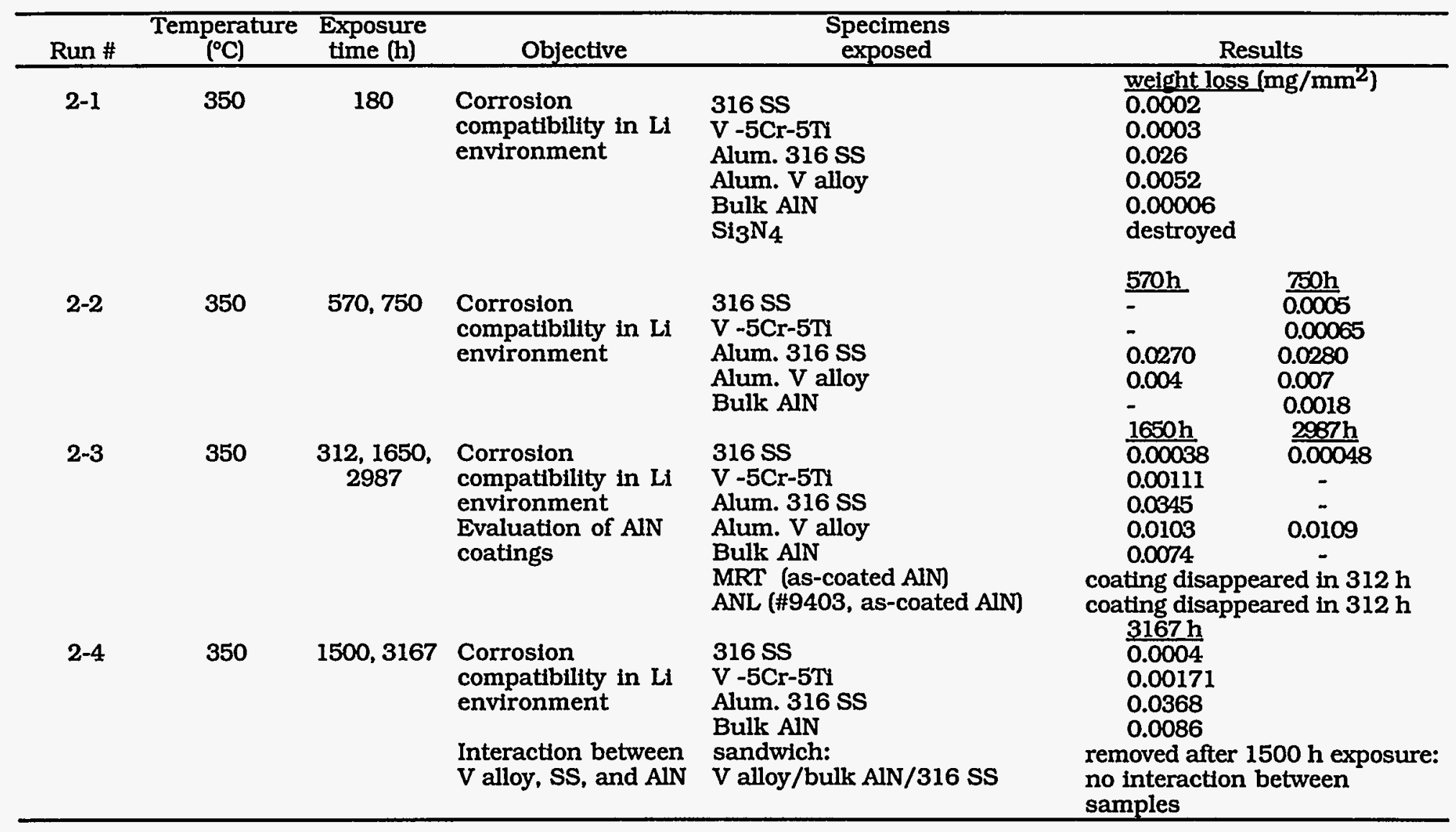


Table 2. (Cont'd)

\begin{tabular}{|c|c|c|c|c|c|c|}
\hline $2-5$ & 300 & 120 & $\begin{array}{l}\text { Evaluation of AlN } \\
\text { coatings in as-coated } \\
\text { condition for } 120 \mathrm{~h}\end{array}$ & $\begin{array}{l}\text { V }-5 C r-5 T \\
\text { Alum. V alloy } \\
\text { Bulk AlN } \\
\text { ANL-5.2 } \mu \mathrm{m} \text { AlN as-coated } \\
\text { MRT \#20 AlN, as-coated } \\
\text { MRT\# } 24 \text { AlN, as-coated }\end{array}$ & $\begin{array}{l}\text { weight loss } \\
0.000 \\
0.020 \\
0.0098 \\
0.0104 \\
0.001 \\
0.0011\end{array}$ & $\begin{array}{l}\mathrm{C} / \mathrm{R} \\
\mathrm{C} \\
\mathrm{C} \\
\mathrm{R} \\
\mathrm{R} \\
\mathrm{C} \\
\mathrm{C}\end{array}$ \\
\hline $2-6$ & 300 & 430 & $\begin{array}{l}\text { Evaluation of AlN } \\
\text { coatings in as-coated } \\
\text { condition for } 430 \mathrm{~h}\end{array}$ & $\begin{array}{l}\mathrm{V}-5 \mathrm{Cr}-5 \mathrm{TI} \\
\text { Alum. V alloy } \\
\text { Bulk AlN } \\
\text { ANL-5.2 } \mu \mathrm{m} \text { AlN as-coated } \\
\text { MRT \#20 AlN, as-coated } \\
\text { MRT\# } 24 \text { AlN, as-coated }\end{array}$ & $\begin{array}{l}0.0006 \\
0.00098 \\
0.0055 \\
0.0056 \\
0.00038 \\
0.00035\end{array}$ & $\begin{array}{l}\mathrm{C} \\
\mathrm{C} \\
\mathrm{R} \\
\mathrm{R} \\
\mathrm{C} \\
\mathrm{C}\end{array}$ \\
\hline $2-7$ & 300 & 480 & $\begin{array}{l}\text { Evaluation of AlN } \\
\text { coatings with } \\
\text { pretreatment }\end{array}$ & $\begin{array}{l}\text { MRT AlN } / 316 / 900^{\circ} \mathrm{C} \text { pretreat } \\
\text { CAT AlN }(\# 27,1.26 \mu \mathrm{m}) \\
\text { AlN bulk }\end{array}$ & $\begin{array}{l}0.0409 \\
0.00076 \\
0.0049\end{array}$ & $\begin{array}{l}\mathrm{C} \\
\mathrm{C} \\
\mathrm{R}\end{array}$ \\
\hline $2-8$ & 300 & 600 & $\begin{array}{l}\text { Evaluation of AlN } \\
\text { coatings with } \\
\text { pretreatment at } \\
900^{\circ} \mathrm{C}\end{array}$ & $\begin{array}{l}\text { MRT AlN } / \mathrm{V} / 900^{\circ} \mathrm{C} \text { pretreat } \\
\text { MRT AlN } / \mathrm{Al} \text { onV } / 900^{\circ} \mathrm{C} \text { pretreat } \\
\text { BIRL AlN } / \mathrm{V} / 900^{\circ} \mathrm{C} \text { pretreat } \\
\text { BIRL TIN+AlN } / \mathrm{V} / 900^{\circ} \mathrm{C} \text { pretreat }\end{array}$ & $\begin{array}{l}0.0168 \\
0.006 \\
0.00025 \\
0.0088\end{array}$ & $\begin{array}{l}\mathrm{R} \\
\mathrm{R} \\
\mathrm{R} \\
\mathrm{C}\end{array}$ \\
\hline $2-9$ & 300 & 456 & $\begin{array}{l}\text { Evaluation of AlN } \\
\text { coatings with } \\
\text { pretreatment at } \\
700^{\circ} \mathrm{C} \text { for } 284 \mathrm{~h}\end{array}$ & $\begin{array}{l}\text { MRT AlN } / \mathrm{V} / 700^{\circ} \mathrm{C} \text { pretreat } \\
\text { MRT AlN } / \mathrm{Al} \text { onV } / 700^{\circ} \mathrm{C} \text { pretreat } \\
\text { BIRL AlN } / \mathrm{V} / 700^{\circ} \mathrm{C} \text { pretreat } \\
\text { BIRL TIN+AIN } / \mathrm{V} / 700^{\circ} \mathrm{C} \text { pretreat }\end{array}$ & $\begin{array}{l}0.016 \\
0.046 \\
0.005 \\
0.012\end{array}$ & $\begin{array}{l}\mathbf{R} \\
\text { partially } R \\
\text { partially } R \\
\mathbf{C}\end{array}$ \\
\hline \multirow[t]{2}{*}{$2-10$} & \multirow[t]{2}{*}{300} & \multirow[t]{2}{*}{5000} & \multirow[t]{2}{*}{$\begin{array}{l}\text { Long-term } \\
\text { performance of } \\
\text { preformed AlN and } \\
\mathrm{Al}_{2} \mathrm{O}_{3} \text { coatings at } \\
300^{\circ} \text { in } \mathrm{LI}\end{array}$} & $\begin{array}{l}\text { MRT AlN/V as-coated } \\
\text { MRT AlN/Alum. V as-coated } \\
\text { MRT AlN/V/900 } \mathrm{C} \text { pretreat } \\
\text { MRT AlN/Alum.V } / 900^{\circ} \mathrm{C} \\
\text { pretreat } \\
\mathrm{Al}_{2} \mathrm{O}_{3} \text { coating on } 304 \mathrm{SS}\end{array}$ & $\begin{array}{l}0.0436 \\
0.0121 \\
0.0261 \\
0.0258 \\
0.0179\end{array}$ & $\begin{array}{l}\mathrm{C} \\
\mathbf{C} \\
\mathrm{R} \\
\mathrm{R} \\
\mathrm{C}\end{array}$ \\
\hline & & & & $\begin{array}{l}\text { Long AIN/V sample for } \\
\text { resistance measurement }\end{array}$ & \multicolumn{2}{|c|}{$\begin{array}{l}\quad 0.0179 \quad c \\
\text { exhibited cracks in edges and } \\
\text { corners / } O \Omega \text { on immersion in } \\
\mathrm{L}_{\mathrm{i}}\end{array}$} \\
\hline
\end{tabular}


Table 3. Experiments performed in lithium with higher activities of nitrogen and/or aluminum

\begin{tabular}{|c|c|c|c|c|c|c|}
\hline Run \# & $\begin{array}{c}\text { Temperature } \\
\left({ }^{\circ} \mathrm{C}\right)\end{array}$ & $\begin{array}{c}\text { Exposure } \\
\text { time (h) }\end{array}$ & Objective & $\begin{array}{c}\text { Specimens } \\
\text { exposed }\end{array}$ & \multicolumn{2}{|r|}{ Results } \\
\hline 3-1 & 400 & 164 & $\begin{array}{l}\text { Corrosion } \\
\text { compatibility in } \mathrm{Li} \\
\text { environment }\end{array}$ & $\begin{array}{l}316 \text { SS } \\
\text { V -5Cr-5Ti } \\
\text { Alum. } 316 \text { SS } \\
\text { Alum. V alloy } \\
\text { Bulk AlN } \\
\text { MRT (as-coated AlN on 316) } \\
\text { MRT (as-coated AlN on V } \\
\text { alloy) ANL (\#9405, as-coated } \\
\text { AlN) }\end{array}$ & $\begin{array}{l}\text { weight lt } \\
0.0017 \\
0.0000 \\
0.0091 \\
0.0020 \\
(-0.021) \\
0.0423 \\
0.045 \\
0.0026\end{array}$ & $\begin{array}{l}\text { coating destroyed } \\
\text { coating destroyed }\end{array}$ \\
\hline $3-2$ & 400 & 320,484 & $\begin{array}{l}\text { Corrosion } \\
\text { compatibility in } \mathrm{Li} \\
\text { environment } \\
320 \mathrm{~h} \text { for coatings }\end{array}$ & $\begin{array}{l}316 \text { SS } \\
\text { V }-5 \mathrm{Cr}-5 \mathrm{TY} \\
\text { Alum. } 316 \text { SS } \\
\text { Alum. V alloy } \\
\text { Bulk AlN } \\
\text { MRT (as-coated AlN on V } \\
\text { alloy) }\end{array}$ & $\begin{array}{l}0.0494 \\
0.0000 \\
0.0132 \\
0.0033 \\
0.0393 \\
0.0434\end{array}$ & coating destroyed \\
\hline $\begin{array}{c}3-3 \\
\left(\mathrm{~N}_{2} \text { gas }\right. \\
\text { bubbled } \\
\text { in to } \mathrm{LI} \\
\text { for } 24 \mathrm{~h} \text { ) }\end{array}$ & 300 & 120 & $\begin{array}{l}\text { Evaluation of AlN } \\
\text { coatings after } 120 \mathrm{~h} \\
\text { exposure }\end{array}$ & $\begin{array}{l}\mathrm{V}-5 \mathrm{Cr}-5 \mathrm{TI} \\
\text { Alum. V alloy } \\
\text { Bulk AlN } \\
\text { MRT (as-coated AlN on V } \\
\text { alloy) } \\
\text { MRT (as-coated AlN on V } \\
\text { alloy) ANL (\#9404, as-coated } \\
\text { AlN) (AlN/V alloy, } 900^{\circ} \mathrm{C} \\
\text { MRT (AlN } \\
\text { pretreat) }\end{array}$ & $\begin{array}{l}0.0003 \\
0.0128 \\
0.0164 \\
0.0007 \\
0.0015 \\
0.0072 \\
0.0018\end{array}$ & $\begin{array}{l}\mathrm{CR} \\
\mathrm{C} \\
\mathrm{C} \\
\mathrm{R} \\
\mathrm{C} \\
\mathrm{C} \\
\mathrm{R} \\
\mathrm{R}\end{array}$ \\
\hline $3-4$ & 300 & 430 & $\begin{array}{l}\text { Evaluation of AlN } \\
\text { coatings after } 430 \mathrm{~h} \\
\text { exposure }\end{array}$ & $\begin{array}{l}\mathrm{V}-5 \mathrm{Cr}-5 \mathrm{TI} \\
\text { Alum. V alloy } \\
\text { Bulk AlN } \\
\text { MRT (as-coated AlN on } \mathrm{V} \\
\text { alloy) } \\
\text { MRT }^{-} \text {(as-coated } \text { AlN }^{-} \text {on } \mathrm{V} \\
\text { alloy) ANL ( } 9404, \text { as-coated } \\
\text { AlN) } \\
\text { MRT (AlN/V alloy, } 900^{\circ} \mathrm{C} \\
\text { pretreat) }\end{array}$ & $\begin{array}{l}0.0006 \\
0.0139 \\
0.030 \\
0.0011 \\
0.0053 \\
0.0115 \\
0.0218\end{array}$ & $\begin{array}{l}\mathbf{C} \\
\mathrm{C} \\
\mathrm{R} \\
\mathrm{C} \\
\mathrm{C} \\
\mathrm{R} \\
\mathrm{R}\end{array}$ \\
\hline
\end{tabular}


Table 3. (Cont'd)

\begin{tabular}{|c|c|c|c|c|c|c|}
\hline 3-5 & 300 & 480 & $\begin{array}{l}\text { Evaluation of } \mathrm{AlN} \\
\text { coatings with } 900^{\circ} \mathrm{C} \\
\text { pretreatment }\end{array}$ & $\begin{array}{l}\text { MRT V/AlN with } 900^{\circ} \mathrm{C} \text { pretreat } \\
\text { MRT SS/AlN with } 900^{\circ} \mathrm{C} \text { pretreat, } \\
\text { ANL V/AlN } 1.5 \mu \mathrm{m} 900^{\circ} \mathrm{C} \text { pretreat } \\
\text { CAT \#24 with } 900^{\circ} \mathrm{C} \text { pretreat } \\
\text { AlN bulk. }\end{array}$ & $\begin{array}{l}0.009 \\
0.042 \\
0.0008 \\
0.0007 \\
0.004\end{array}$ & $\begin{array}{l}\text { R } \\
\mathbf{C} \\
\mathbf{C} \\
\mathbf{C} \\
\mathrm{R}\end{array}$ \\
\hline $3-6$ & 300 & 456 & $\begin{array}{l}\text { Evaluation of AlN } \\
\text { coatings with } 700^{\circ} \mathrm{C} \\
\text { pretreatment }\end{array}$ & $\begin{array}{l}\text { MRT V/AlN with } 700^{\circ} \mathrm{C} \text { pretreat } \\
\text { MRT alum. V/AlN } 700^{\circ} \mathrm{C} \text { pretreat }\end{array}$ & $\begin{array}{l}0.0355 \\
0.027\end{array}$ & $\begin{array}{l}\mathbf{R} \\
\text { partially } R\end{array}$ \\
\hline $\begin{array}{l}\text { Bullet } \\
\text { Test I }\end{array}$ & 300 & - & $\begin{array}{l}\text { In-situ measurement } \\
\text { of resistance of AlN- } \\
\text { coated } V \text { alloy bullet }\end{array}$ & $\begin{array}{l}\text { V alloy with MRT AlN in as- } \\
\text { coated condition }\end{array}$ & \multicolumn{2}{|c|}{$\begin{array}{l}\text { Resistance before insertion in } \\
\text { Li:1.2 } 2 \times 10^{5} \Omega \\
\text { Resistance immediately after } \\
\text { insertion } 0 \Omega\end{array}$} \\
\hline $\begin{array}{l}\text { Bullet } \\
\text { Test II }\end{array}$ & 300 & - & $\begin{array}{l}\text { In-situ measurement } \\
\text { of resistance of AlN- } \\
\text { coated V alloy bullet }\end{array}$ & $\begin{array}{l}\text { V alloy with MRT AlN bullet } \\
\text { with } 900^{\circ} \mathrm{C} \text { pretreatment } \\
\text { inserted } 5 \mathrm{~cm} \text { in } \mathrm{Li}\end{array}$ & \multicolumn{2}{|c|}{$\begin{array}{l}\text { Resistance before insertion in } \\
\text { Li: } 20,000 \Omega \\
\text { Resistance decreased and } \\
\text { reached } 0 \Omega \text { within } 5 \text { min after } \\
\text { insertion in to } \mathrm{Li}\end{array}$} \\
\hline $\begin{array}{l}\text { Chemical } \\
\text { modifica- } \\
\text { tion to Li }\end{array}$ & 300 & - & & $\begin{array}{l}\text { Additon of } 100 \mathrm{~g} \text { high-purity } \\
\text { AlN powder }\end{array}$ & & \\
\hline \multirow[t]{2}{*}{$3-7$} & 300 & 24,620 & & $\begin{array}{l}V-5 C r-5 T i \text { (no coating) } \\
\text { Alum. V alloy (no coating) } \\
\text { MRT (as-coated AlN on V } \\
\text { alloy) }\end{array}$ & \multirow{2}{*}{\multicolumn{2}{|c|}{$\begin{array}{l}\text { bare: } 0 \Omega \\
\text { Al/V: } 2-5 \Omega \\
\text { High resistance on one side, } \\
\text { flaking on other side } \\
\text { insulating, coating flakes }\end{array}$}} \\
\hline & & & & MRT AlN coated V alloy & & \\
\hline $\begin{array}{l}\text { Al } \\
\text { addition } \\
\text { LisN } \\
\text { addition }\end{array}$ & 500 & & & $\begin{array}{l}\text { Al added to } \mathrm{Li}: 14.2 \mathrm{~g} \rightarrow 4057 \mathrm{ppm} \\
\mathrm{N} \text { added as } \mathrm{Li} 3 \mathrm{~N}: 25.55 \mathrm{~g} \rightarrow 2929 \\
\mathrm{ppm} \mathrm{N}\end{array}$ & \multicolumn{2}{|c|}{$\begin{array}{l}N \text { in } \mathrm{Li} \text { in excess of AIN: } \\
825 \mathrm{ppm}\end{array}$} \\
\hline
\end{tabular}


Table 3. (Cont'd)

\begin{tabular}{|c|c|c|c|c|c|}
\hline 3-8 & 500 & 120 & $\begin{array}{l}\text { In-situ coating of } \\
\text { AlN on V alloy at } \\
500^{\circ} \mathrm{C} \\
\text { Evaluation of } \\
\text { preformed coatings } \\
\text { at } 500^{\circ} \mathrm{C} \text { in } \mathrm{Li} \text { with } \\
\text { increased } \mathrm{N} \text { and } \mathrm{Al} \\
\text { activity }\end{array}$ & $\begin{array}{l}\text { V -5Cr-5TY } \\
\text { Alum. V alloy } \\
\text { MRT V/AIN with } 900^{\circ} \mathrm{C} \text { pretreat } \\
\text { MRT V/AIN with } 900^{\circ} \mathrm{C} \text { pretreat } \\
\text { MRT V/AlN (coated on one side) } \\
\text { with } 900^{\circ} \mathrm{C} \text { pretreat }\end{array}$ & $\begin{array}{r}\mathbf{C} \\
\mathbf{C} \\
\mathbf{R} \\
\mathbf{R} \\
\text { coated side: } \\
\mathbf{R} \\
\text { uncoated side: } \mathbf{C}\end{array}$ \\
\hline $3-9$ & 300 & 120 & $\begin{array}{l}\text { In-situ coating of } \\
\text { AlN on V alloy at } \\
300^{\circ} \mathrm{C} \\
\text { Evaluation of } \\
\text { preformed coatings } \\
\text { at } 300^{\circ} \mathrm{C} \text { in Li with } \\
\text { increased } \mathrm{N} \text { and } \mathrm{Al} \\
\text { activity }\end{array}$ & $\begin{array}{l}\text { V -5Cr-5TY } \\
\text { Alum. V alloy } \\
\text { MRT V/AlN with } 900^{\circ} \mathrm{C} \text { pretreat } \\
\text { MRT V/AIN with } 900^{\circ} \mathrm{C} \text { pretreat } \\
\text { MRT V/AlN with } 900^{\circ} \mathrm{C} \text { pretreat } \\
\text { MRT V/AlN (coated on one side) } \\
\text { with } 900^{\circ} \mathrm{C} \text { pretreat ( } 2 \text { samples) } \\
\text { "Hot dip" Al-coated V alloy (KfK) }\end{array}$ & $\begin{array}{r}\mathrm{C} \\
\mathrm{C} \\
\mathrm{R} \\
\mathrm{R} \\
\mathrm{R} \\
\text { coated side: } \\
\mathrm{R} \\
\text { uncoated side: } \\
\mathrm{C}\end{array}$ \\
\hline
\end{tabular}


Experiments in Li of Normal Purity

In Runs 2-1 and 2-2, specimens of Type 316 stainless steel, V-5Cr-5Ti alloy with and without prealuminization, as well as bulk AlN, were exposed to $\mathrm{Li}$ and the results were presented in an earlier report. 1 In Run 2-3, in addition to above specimens, AlN-coated (from MRT and ANL) specimens of $\mathrm{V}-5 \mathrm{Cr}-5 \mathrm{Ti}$ alloy were included. The results showed that the coatings from the as-coated specimens disappeared into $\mathrm{Li}$, indicating either spallation due to lack of inadequate bonding with substrate or dissolution of the coating in $\mathrm{Li}$. Because the coated specimens, when removed from $\mathrm{Li}$, exhibited very clean substrate alloy surfaces with no coating at all, we surmise that the PVD-coated samples in as-coated condition have inadequate bonding with the substrate. In Run 2-4, corrosion experiments were continued to exposure time of $3167 \mathrm{~h}$, and also a sandwich specimen of $\mathrm{V}$ alloy/bulk AlN/316 stainless steel was exposed for $1500 \mathrm{~h}$ to evaluate the substrate-coating interactions. Details on the corrosion test results, the substrate/coating interactions, and $X$-ray diffraction data for and microstructural evaluation of all the Li-exposed specimens were discussed in Ref. 1. The results generally showed that the corrosion rates for Type 316 stainless steel and $\mathrm{V}-5 \mathrm{Cr}-5 \mathrm{Ti}$ alloy were negligibly small at $300-350^{\circ} \mathrm{C}$ in $\mathrm{Li}$ after $3167 \mathrm{~h}$ of exposure and the subsequent experiments emphasized the compatibility of AlN coatings in an Li environment.

In Runs 2-5 and 2-6, coatings made at ANL and MRT were exposed for 120 and $430 \mathrm{~h}$ at $300^{\circ} \mathrm{C}$ in $\mathrm{Li}$ of normal purity. Further, electrical resistivity of these coatings were measured, using the procedure described in Ref. 1 , before and after exposure to $\mathrm{Li}$. It is evident that the MRT-developed AlN coating in as-coated condition lost its resistivity after exposure to $\mathrm{Li}$, while the resistivity of the ANL-developed AlN coating was high after 120 and 430 $\mathrm{h}$ at $300^{\circ} \mathrm{C}$. The insulating characteristics of the coated specimens after $\mathrm{Li}$ exposure are indicated by letters " $\mathrm{C}$ " for conducting and " $\mathrm{R}$ " for high resistance in Tables 2 and 3. Figure 21 shows an SEM photomicrograph in cross section, and EDX depth profiles for $\mathrm{Al}, \mathrm{N}, \mathrm{V}, \mathrm{Cr}$, and $\mathrm{Ti}$, of an ANLdeveloped, AlN-coated, prealuminized V-5Cr-5Ti alloy specimen after $430 \mathrm{~h}$ exposure in Run $2-6$ at $300^{\circ} \mathrm{C}$ to an $\mathrm{Li}$ environment of normal purity. Because this specimen was prealuminized, a thin layer of $(\mathrm{Al}, \mathrm{V})$ nitride seems to form as an intermediate layer during the coating process, primarily because the specimen was heated to $350-450^{\circ} \mathrm{C}$ during coating in the ANL approach.

The fact that the ANL-developed coating in which the substrate was heated to $350-450^{\circ} \mathrm{C}$ survived the $\mathrm{Li}$ exposure while the MRT-developed coating in which the substrate attained a maximum of $200^{\circ} \mathrm{C}$ led to the 

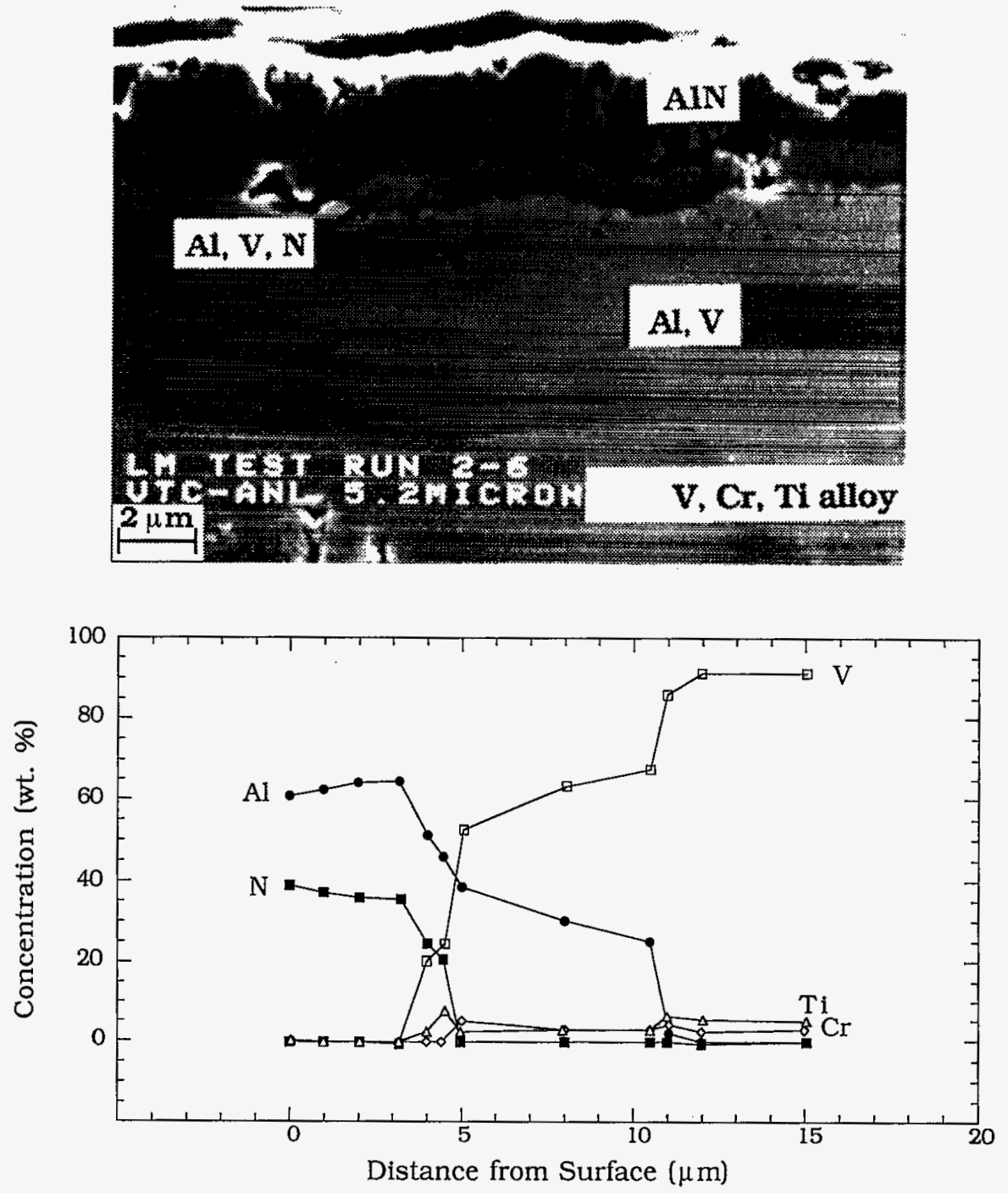

Fig. 21. SEM photomicrograph in cross section and EDX depth profiles for $\mathrm{Al}, \mathrm{N}, \mathrm{V}, \mathrm{Cr}$, and Ti in ANL-developed, AlN-coated, prealuminized $\mathrm{V}-5 \mathrm{Cr}-5 \mathrm{Ti}$ alloy specimen after $430 \mathrm{~h}$ exposure in Run $2-6$ at $300^{\circ} \mathrm{C}$ to $\mathrm{Li}$ environment of normal purity

possibility of improved adhesion of the coating to the substrate by increasing the substrate temperature during coating. It was evident that the adhesion of coatings developed by PVD/reactive-sputtering processes is much lower than desired and that some improvement is needed to better bond the coating to the substrate and also to eliminate or minimize the porosity and microdefects in coatings developed by relatively low-temperature PVD processes. As a result, a thermal/chemical hardening treatment was attempted in which the AlN-coated specimens were heated to $700-900^{\circ} \mathrm{C}$ in a controlled environment prior to exposure to the Li environments. Such an 
approach seemed to harden the coating, as evidenced by substantial improvement in scratch resistance of the coating surface. Several AlNcoated specimens were given a hardening treatment at 900 and $700^{\circ} \mathrm{C}$ and subsequently exposed to $\mathrm{Li}$ at $300^{\circ} \mathrm{C}$. In Run 2-7, an MRT-developed AIN coating on Type 316 stainless steel substrate with a hardening treatment of the coating at $900^{\circ} \mathrm{C}$, a bulk AlN specimen, and a thin AlN coating developed by CAT were exposed to $\mathrm{Li}$ at $300^{\circ} \mathrm{C}$. The MRT-developed coating still flaked off in $\mathrm{Li}$ and the specimen, due to its lack of coating, exhibited an electrically conducting behavior. The CAT-developed coating, being very thin, also disappeared during $\mathrm{Li}$ exposure.

Subsequently, several AlN-coated specimens of V-5Cr-5Ti alloy with $900^{\circ} \mathrm{C}$ hardening treatment were prepared and exposed to $\mathrm{Li}$ for $600 \mathrm{~h}$ at $300^{\circ} \mathrm{C}$ in Run 2-8. As shown in Table 2, all of the specimens performed well in $\mathrm{Li}$ and the coatings exhibited high resistance values. In contrast, the sample with a bond coating of TiN had significantly low resistance after Li exposure. Figure 22 shows SEM photomicrographs of cross sections of $900^{\circ} \mathrm{C}$-hardened AlN-coated specimens after $600 \mathrm{~h}$ exposure to $\mathrm{Li}$ in Run 28. The substrates in samples \#9 (Fig. 22a) and \#13 (Fig. 22b) were initially in bare and prealuminized condition, respectively. The AIN coating deposited by MRT had thicknesses of 10-12 $\mu \mathrm{m}$. After Li exposure, the coating surface exhibited a reaction product that contained only $\mathrm{Al}$ and $\mathrm{O}$, based on EDX analysis. The photomicrograph in Fig. 22c is for a $900^{\circ}$ hardened AlN-coated specimen developed by BIRL and exposed to $\mathrm{Li}$ along with samples \#9 and \#13 mentioned above. Thicknesses of BIRL-developed coatings were 4-6 $\mu \mathrm{m}$, and specimen \#56-1 also developed an Al- and O-rich reaction product after $\mathrm{Li}$ exposure. X-ray diffraction analysis of the three specimens (\#9, 13, and 56-1) showed hexagonal AlN as the predominant phase in all three specimens; no $\mathrm{Li}, \mathrm{Al}, \mathrm{O}$ and/or $\mathrm{N}$ compounds were observed. Of course, because these Li-exposed specimens were cleaned in alcohol and water prior to analysis, all the Li-containing compounds would have dissolved in water and none is expected in the analysis.

To examine whether similar insulating characteristics of the coatings can be maintained in $\mathrm{Li}$ with a lower temperature for hardening the coatings, several specimens were prepared with a thermal/chemical treatment at $700^{\circ} \mathrm{C}$ (instead of $900^{\circ} \mathrm{C}$ ) for $284 \mathrm{~h}$, and subsequently exposed to $\mathrm{Li}$ for $456 \mathrm{~h}$ at $300^{\circ} \mathrm{C}$ in Run 2-9. Figure 23 shows SEM photomicrographs of cross sections of $700^{\circ} \mathrm{C}$-hardened AlN-coated specimens after a $456 \mathrm{~h}$ exposure to an Li environment of normal purity. An MRT-coated specimen of $\mathrm{V}$ alloy exhibited good insulating characteristics; the MRT coating on a prealuminized $\mathrm{V}$ alloy showed high resistance on only one side of the specimen while the other side exhibited flaking and 

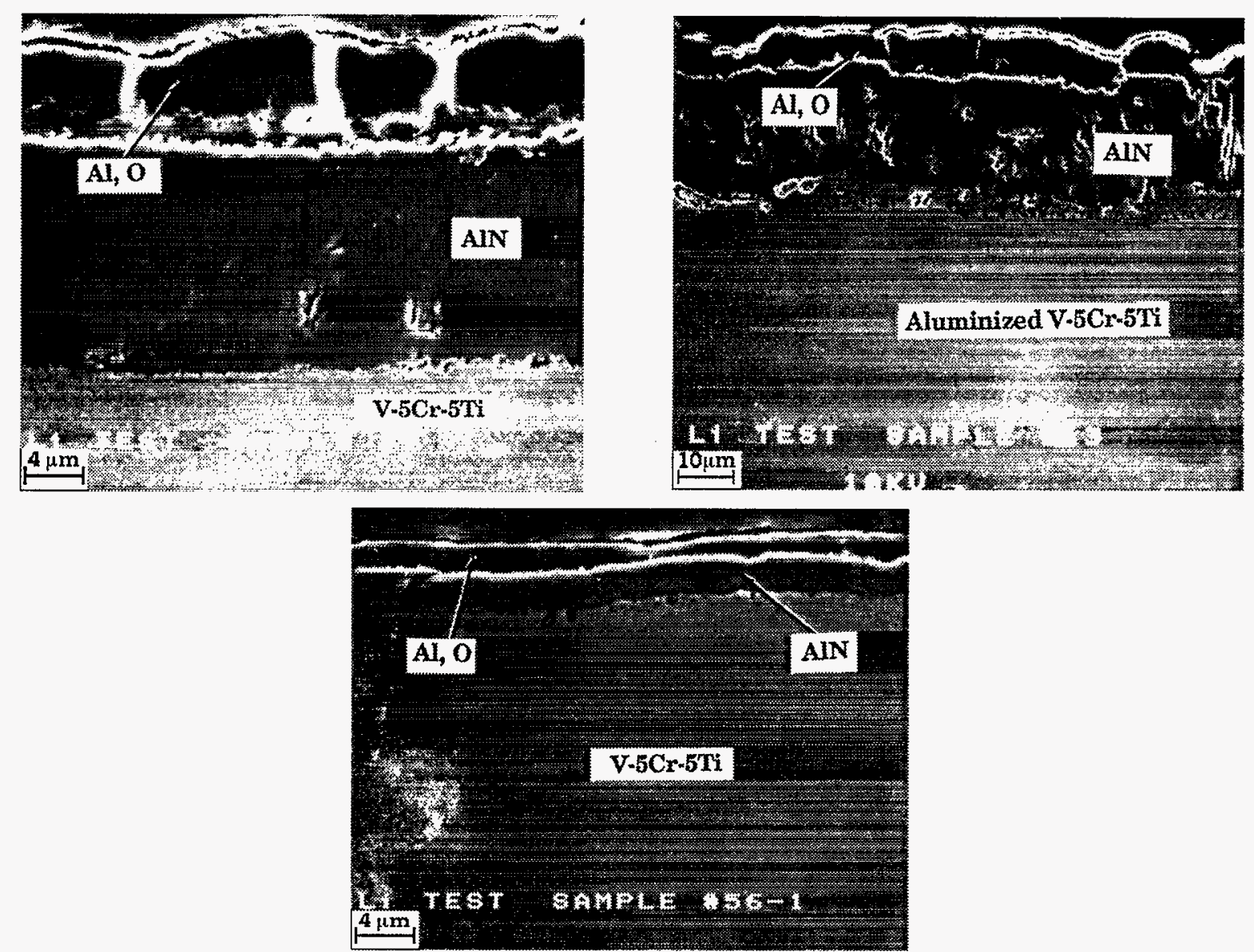

Fig. 22. SEM photomicrographs of cross sections of $900^{\circ} \mathrm{C}-$ hardened AlNcoated specimens after $600 \mathrm{~h}$ exposure in Run $2-8$ to $\mathrm{Li}$ environment of normal purity

cracking of the coating. Similar characteristics were noted for the BIRLdeveloped coating on $\mathrm{V}$ alloy. The specimen with a bond coating of TiN exhibited almost no resistance, as indicated by the complete loss of coating during $\mathrm{Li}$ exposure. The lower hardening temperature seems to reduce the reaction between the coating and the $\mathrm{Li}$ environment, as evidenced by the thinner layer of the reaction product and also by the lack of continuous coverage of the coating.

A long-term endurance test was conducted in Run 2-10 by exposing to $\mathrm{Li}$ for $5000 \mathrm{~h}$ at $300^{\circ} \mathrm{C}$ specimens of $\mathrm{V}$ alloy with and without prealuminization, AlN coated samples of $\mathrm{V}$ alloy with and without prealuminization, and a prealuminized Type 304 stainless steel pipe sample with a pack-diffusion $\mathrm{Al}_{2} \mathrm{O}_{3}$ coating. Figure 24 shows SEM photomicrographs of specimens after $5000 \mathrm{~h}$ exposure to Li. The AlNcoated specimens exhibited high resistance after exposure to $\mathrm{Li}$, and the $\mathrm{Al}_{2} \mathrm{O}_{3}$-coated stainless steel specimen lost the coating in Li. In the same 

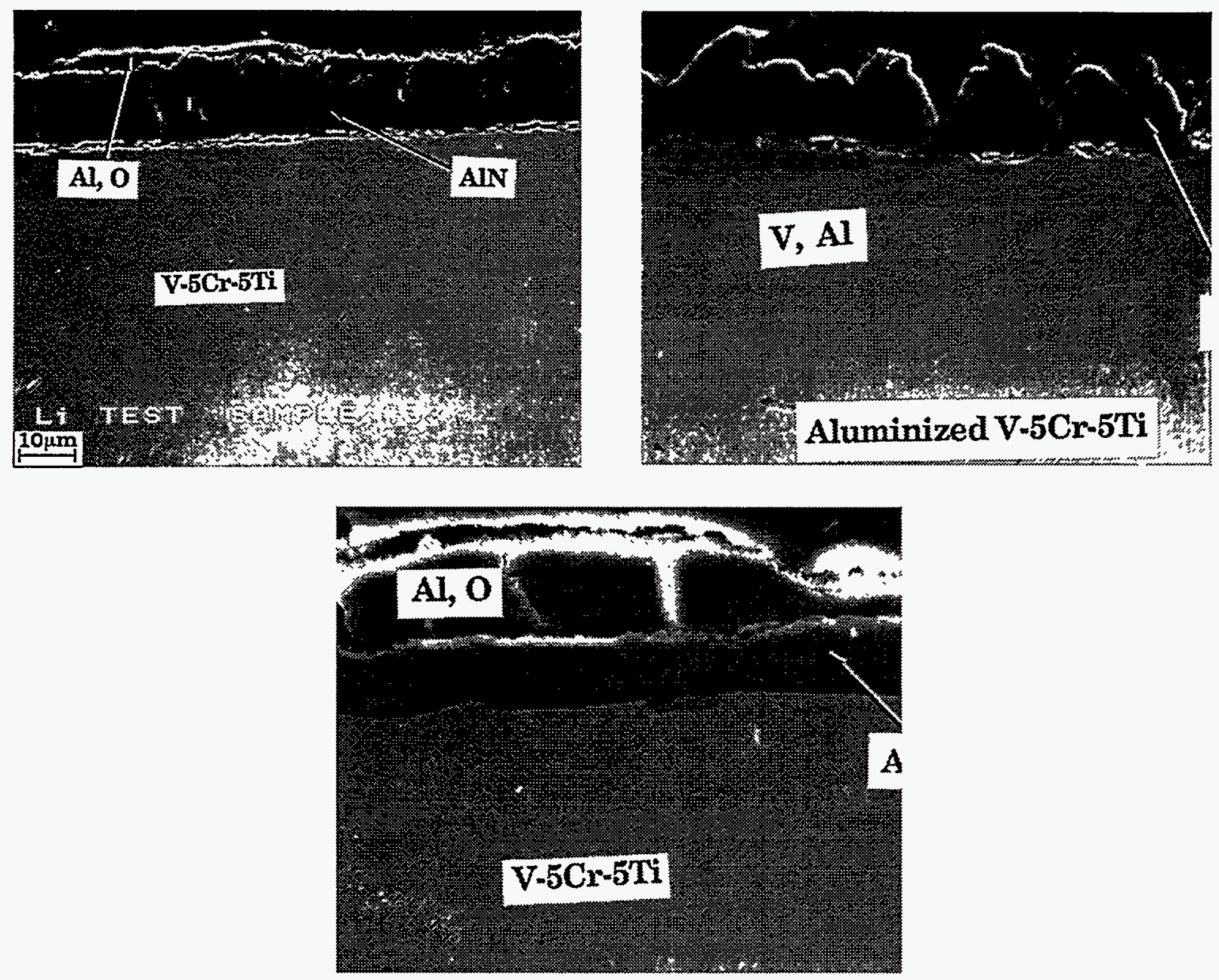

Fig. 23. SEM photomicrographs of cross sections of $700^{\circ} \mathrm{C}-$ hardened AlNcoated specimens after $456 \mathrm{~h}$ exposure in Run 2-9 to Li environment of normal purity

run, a flat coupon (measuring $7.5 \times 1.25 \times 0.1 \mathrm{~cm}$ ) of AlN-coated $\mathrm{V}$ alloy was exposed to $\mathrm{Li}$ for in-situ resistance measurements. The long specimen exhibited cracks and spallation of the coating at edges and corners of the sample, leading to electrical continuity.

\section{Experiments in Li with Higher Activities of $\mathrm{N}$ and/or $\mathrm{Al}$}

In Runs 3-1 and 3-2, the $\mathrm{Li}$ temperature was maintained at $400^{\circ} \mathrm{C}$ and several specimens with and without AlN coatings were exposed. All of the coated samples exhibited loss of coating during Li exposure. As a result, the $\mathrm{N}$ activity in $\mathrm{Li}$ was increased by bubbling $\mathrm{N}_{2}$-Ar gas mixture into the $\mathrm{Li}$ for $24 \mathrm{~h}$ at $300^{\circ} \mathrm{C}$. Subsequently, several coated specimens were exposed to $\mathrm{Li}$ for $120 \mathrm{~h}$ in Run 3-3. The coating with a $900^{\circ} \mathrm{C}$ thermal/chemical treatment exhibited high resistance after the $\mathrm{Li}$ exposure, while all of the as- 

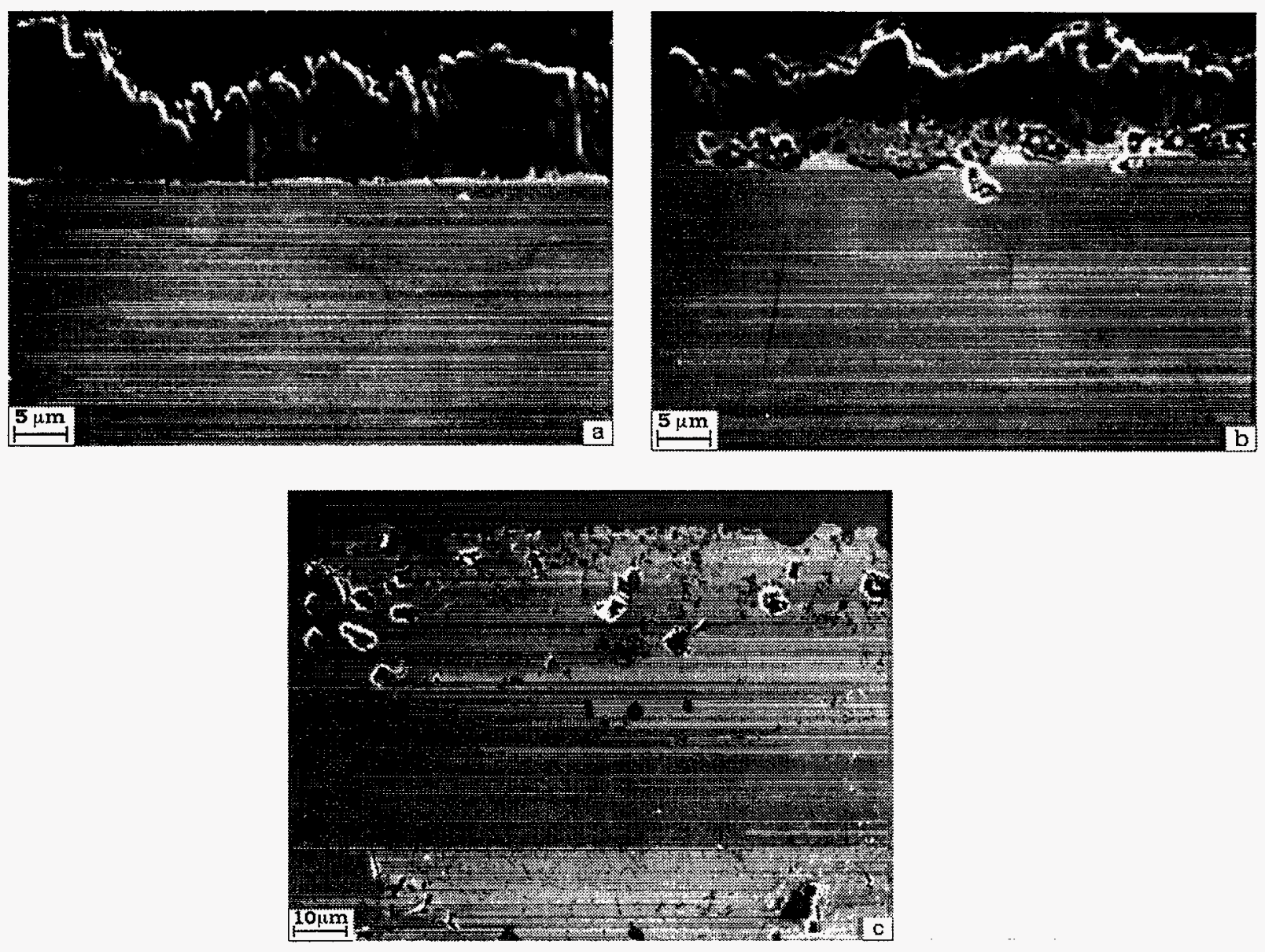

Fig. 24. SEM photomicrographs of cross sections of (a) AlN-coating with $900^{\circ} \mathrm{C}$ hardening on $\mathrm{V}$ alloy, (b) AlN-coating with $900^{\circ} \mathrm{C}$ hardening on prealuminized $\mathrm{V}$ alloy, and (c) pack diffusion $\mathrm{Al}_{2} \mathrm{O}_{3}$ coating on Type 304 stainless steel, after $5000 \mathrm{~h}$ exposure in Run 2-10 at $300^{\circ} \mathrm{C}$ in $\mathrm{Li}$ environment of normal purity

coated specimens lost their coatings. The same specimens were re-exposed to $\mathrm{Li}$ for a total time of $430 \mathrm{~h}$; the coated specimen developed at ANL and that from MRT with a $900^{\circ} \mathrm{C}$ treatment exhibited insulating characteristics.Figure 25 shows an SEM photomicrograph in cross section and EDX depth profiles for $\mathrm{Al}, \mathrm{N}, \mathrm{V}, \mathrm{Cr}$, and $\mathrm{Ti}$, of an MRT-supplied, AlNcoated V-5Cr-5Ti alloy specimen after $430 \mathrm{~h}$ exposure in Run $3-4$ at $300^{\circ} \mathrm{C}$ to an $\mathrm{Li}$ environment in which argon-nitrogen gas was bubbled for $24 \mathrm{~h}$. It is evident that the coating was intact and appears dense and fairly adherent to the substrate alloy. EDX analysis shows that the coating consists predominantly of $\mathrm{Al}$ and $\mathrm{N}$, with almost no contamination from either the impurities in $\mathrm{Li}$ or the substrate constituents. Figure 26 shows an SEM photomicrograph in cross section and EDX depth profiles for $\mathrm{Al}, \mathrm{N}, \mathrm{V}, \mathrm{Cr}$, and $\mathrm{Ti}$ of an ANL-developed, AlN-coated, prealuminized $\mathrm{V}-5 \mathrm{Cr}-5 \mathrm{Ti}$ alloy 

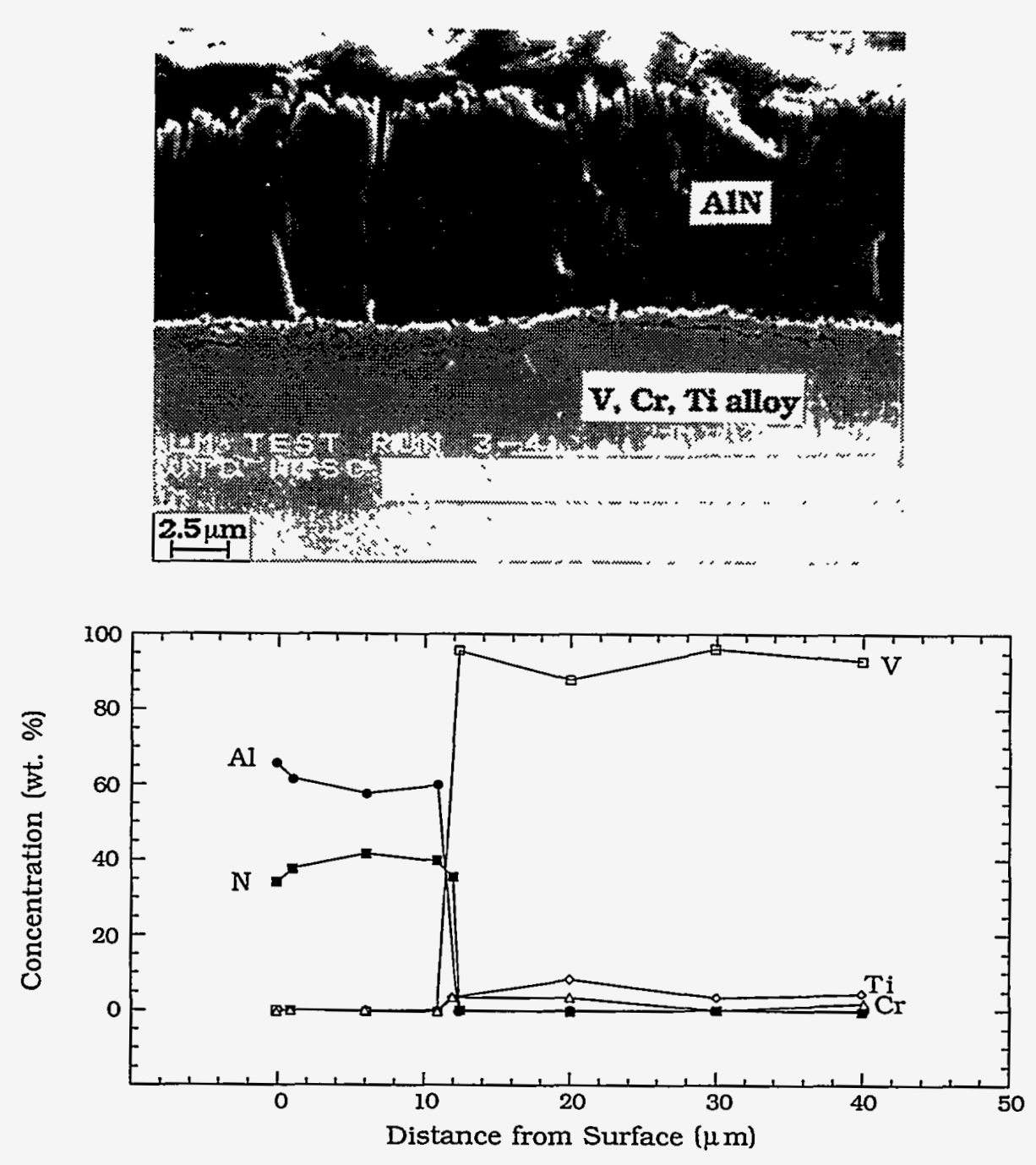

Fig. 25. SEM photomicrograph in cross section and EDX depth profiles for Al, N, V, Cr, and Ti in MRT-supplied, AlN-coated $\mathrm{V}-5 \mathrm{Cr}-5 \mathrm{Ti}$ alloy specimen after $430 \mathrm{~h}$ exposure in Run 3-4 at $300^{\circ} \mathrm{C}$ to $\mathrm{Li}$ environment in which argon-nitrogen gas was bubbled for $24 \mathrm{~h}$

specimen after $430 \mathrm{~h}$ exposure at $300^{\circ} \mathrm{C}$ to an Li environment in Run 3-4. The coatings are somewhat thinner in these specimens than those obtained from MRT, but coating integrity, adhesion to the substrate, and morphology are all very good.

In Run 3-5 (a repeat of Run 3-4), several new coated specimens were exposed to $\mathrm{Li}$ at $300^{\circ} \mathrm{C}$ for $480 \mathrm{~h}$. As before, the MRT-developed coating with thermal/chemical treatment exhibited insulating characteristics. The ANL-developed coating and that obtained from CAT were too thin $10.75-1.5$ $\mu \mathrm{m})$ and did not survive $\mathrm{Li}$ exposure even with a thermal treatment at $900^{\circ} \mathrm{C}$. Run 3-6 is analogous to Run 2-9 in that the AlN-coated specimens were pretreated at $700^{\circ} \mathrm{C}$ prior to $\mathrm{Li}$ exposure. The results showed that the MRT- 
developed coating on $\mathrm{V}$ alloy had adequate resistance, while the MRT-coated prealuminized $\mathrm{V}$ alloy had high resistance on only one side of the specimen.

\section{Hardness of AlN Coatings}

An ultralow load indentation method involving a nano-indenter was used to evaluate the hardness of several of the as-coated and Li-exposed specimens. The instrument is a highly sensitive mechanical property microprobe capable of sensing both load and displacement continuously as indents are made in a sample. The critical components of the indenter include a small metal rod that passes through the center of a three-plate capacitor and is attached to the middle plate. A three-sided pyramidal diamond is brazed to the bottom of the rod, and a small force coil and magnet are positioned at the top. Load is determined by the current to the force coil, and the voltage changes associated with the movement of the middle plate of the capacitor enables the assessment of the displacement.

In general, each sample was indented 10 times. An array was defined across each cross-sectioned coating, with the first five indents targeted at the substrate and the final five in the coating. Information from the loaddisplacement curves and geometry of the indenter, values of the contact areas corresponding to each load were used to calculate the hardness, $\mathrm{H}$, defined as the ratio of the load, P, and contact area, A. Calculation of the contact area for a given indent uses data from a material such as amorphous $\mathrm{SiO}_{2}$ whose modulus is known (assuming that the modulus is not a function of indent depth). Modulus calculations also utilize the slopes of the unloading curves that represent the sample stiffness, $S$, and are related to the composite indenter-sample modulus, ET, by the expression

$$
S=d P / d h=\frac{2}{\sqrt{\pi}} E_{T} \sqrt{A},
$$

where $P$ is load, $h$ is indenter displacement, and $A$ is contact area. The sample modulus, $E_{S}$, is then derived from the composite modulus by the relationship

$$
\mathrm{E}_{\mathrm{T}}=\left(\frac{1-\mathrm{n}_{\mathrm{s}}^{2}}{\mathrm{E}_{\mathrm{s}}}+\frac{1-\mathrm{n}_{\mathrm{i}}^{2}}{\mathrm{E}_{\mathrm{i}}}\right)^{-1},
$$

where $\mathrm{n}$ is Poisson's ratio, and the subscripts $\mathrm{s}$ and $\mathrm{i}$ refer to the sample and indenter, respectively.

Several samples were analyzed by the nano-indentation technique, and for each indent, unloading curves were generated after total displacements 

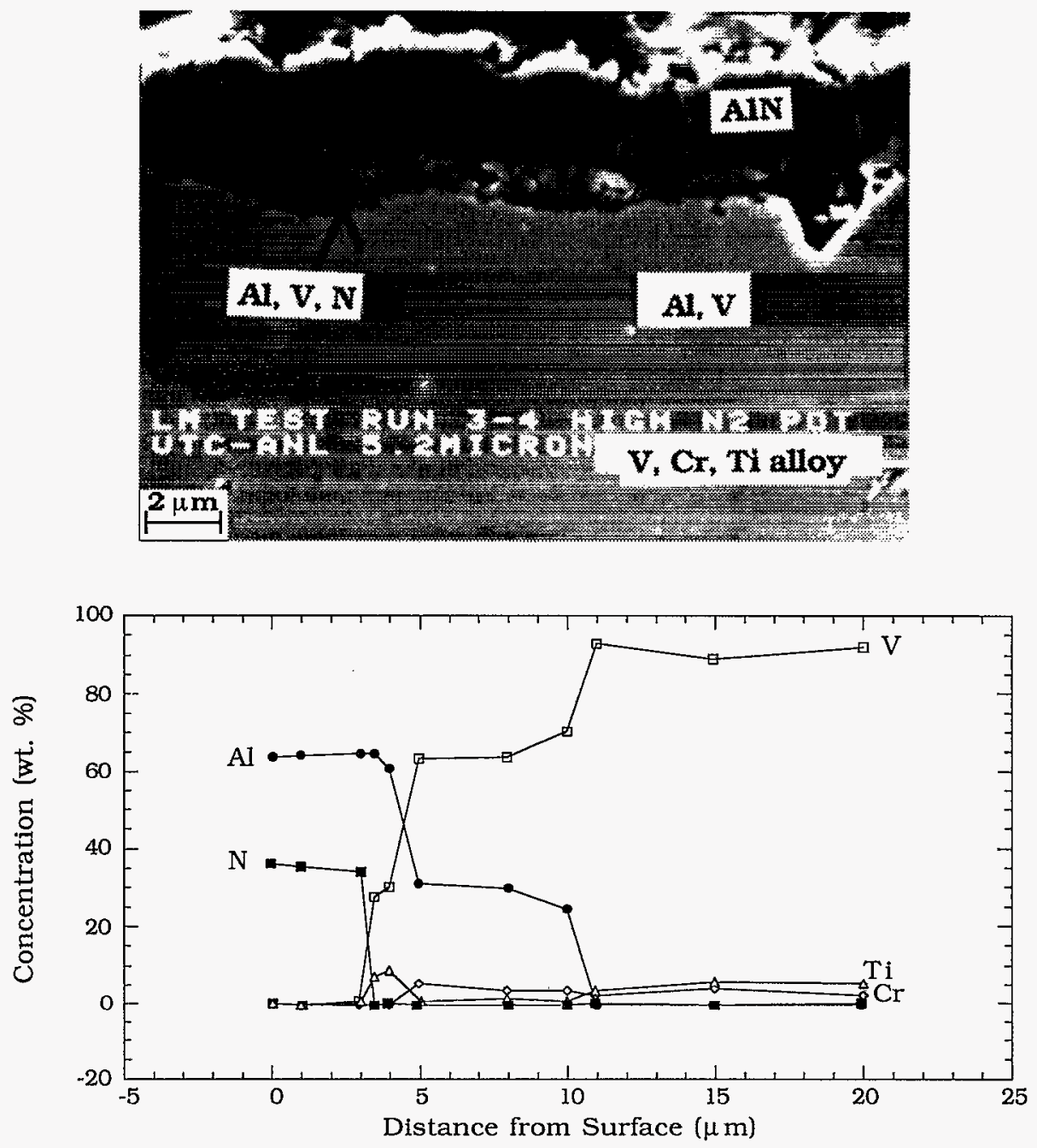

Fig. 26. SEM photomicrograph in cross section and EDX depth profiles for $\mathrm{Al}, \mathrm{N}, \mathrm{V}, \mathrm{Cr}$, and Ti in ANL-developed, AlNcoated, prealuminized $\mathrm{V}-5 \mathrm{Cr}-5 \mathrm{Ti}$ alloy specimen after $430 \mathrm{~h}$ exposure in Run $3-4$ at $300^{\circ} \mathrm{C}$ to $\mathrm{Li}$ environment in which argon-nitrogen gas was bubbled for $24 \mathrm{~h}$

of 40,80 , and $150 \mathrm{~nm}$. Table 4 lists the data obtained on the hardness of the substrate and coating materials after thermal treatment at $900^{\circ} \mathrm{C}$ and after $\mathrm{Li}$ exposures in Runs 2-8 and 2-9. The results indicate that substrate hardness in samples without prealuminization is $14-17 \mathrm{GPa}$. The values in the substrate in the prealuminized samples correspond to an Al-rich zone ofthe $\mathrm{V}$ alloy and are 7-8.5 GPa. The hardness of the AlN coating after $900^{\circ} \mathrm{C}$ treatment but without $\mathrm{Li}$ exposure showed higher values $(28-31 \mathrm{GPa})$ for the specimen without prealuminization treatment than those $(20-24 \mathrm{GPa})$ for specimens with the treatment. 
In the specimens exposed to $\mathrm{Li}$ in Run 2-8, the hardness difference between the coating and the substrate in the specimen without prealuminization is small $(2-3 \mathrm{GPa})$ and may be responsible for the improved adhesion of the coating to the substrate. In the prealuminized specimen exposed in the same $\mathrm{Li}$, the hardness difference is $14-16 \mathrm{GPa}$. In the case of specimens exposed in Run 2-9, the pretreatment temperature was $700^{\circ} \mathrm{C}$ and the hardness of the coating even after $\mathrm{Li}$ exposure is higher in the specimen without prealuminization than that in the specimen with it. This seems to indicate that the absolute values of the hardness for the coating, rather than the difference in hardness between coating and substrate, may play a role in adhesion and spallation. Substantial additional effort is needed to correlate the performance of these coatings with the alloy pretreatment, coating application procedure, and Li exposure conditions.

\section{Electrical Resistance of Li-Exposed AlN Coatings}

After examination of the physical and chemical characterization of the coatings and the coating integrity in as-coated and hardened conditions after exposure to $\mathrm{Li}$ environments, the next steps were to measure the electrical resistances of these Li-exposed initially coated specimens and to compare the measured values with the minimum required for application in fusion reactors. For this purpose, several specimens were selected for resistance measurements. Specimens included those with initially bare and prealuminized conditions, with different sources for the coatings, different hardening treatment, and several exposure times in $\mathrm{Li}$ environments. The specimens were masked and gold-plated, and resistances were measured at room temperature. Figure 27 shows the measured resistance values for several specimens and at different locations within the same specimen. Also shown in the figure is the minimum value for resistance required for application in a fusion reactor blanket.

\section{Bullet Tests}

Experiments were conducted to measure the electrical resistance of AlN coatings in-situ in $\mathrm{Li}$ by using single flat coupons and electrically isolating the specimen by ceramic material from the feed-through assembly in the $\mathrm{Li}$ system. However, these measurements were not successful because the specimens generally developed cracks or the coating spalled at the corners and/or edges of flat specimens, leading to electrical continuity even though the coating was intact over most of the surfaces of the specimens. As a result, bullet specimens, with hemispherical bottoms and female threading on top, were fabricated for in-situ resistance measurements. The bullets were coated with AlN by the same PVD procedure used by MRT for flat coupons prior to $\mathrm{Li}$ exposure. 
Table 4. Hardness data obtained by nano-indentation technique

\begin{tabular}{|c|c|c|c|c|c|c|c|}
\hline Sample \# & $\begin{array}{l}\text { Sample } \\
\text { pretreatment }\end{array}$ & $\begin{array}{l}\text { Li exposure } \\
\text { conditions }\end{array}$ & $\begin{array}{l}\text { Electrical } \\
\text { characteris- } \\
\text { tics }\end{array}$ & $\begin{array}{l}\text { Displace- } \\
\text { menta } \\
\text { (nm) }\end{array}$ & Load $(\mathrm{mN})$ & $\mathrm{E}(\mathrm{GPa})$ & $\mathrm{H}(\mathrm{GPa})$ \\
\hline \multirow[t]{6}{*}{1} & \multirow{6}{*}{$\begin{array}{l}\text { AlN coating on } \\
\text { V-5Cr-5Ti } \\
\text { with } 900^{\circ} \mathrm{C} \\
\text { treatment }\end{array}$} & \multirow[t]{6}{*}{ None } & \multirow{6}{*}{$\begin{array}{l}\text { High } \\
\text { resistance }\end{array}$} & 43.05 & 0.57 & 222.56 & 15.53 \\
\hline & & & & 85.42 & 1.94 & 224.60 & 14.49 \\
\hline & & & & 158.03 & 6.27 & 227.92 & 14.36 \\
\hline & & & & 41.89 & 0.97 & 381.53 & 31.30 \\
\hline & & & & 83.36 & 3.34 & 380.66 & 29.64 \\
\hline & & & & 127.12 & 7.28 & 373.92 & 28.89 \\
\hline \multirow[t]{6}{*}{2} & \multirow{6}{*}{$\begin{array}{c}\text { AlN coating on } \\
\text { prealuminized } \\
\text { V-5Cr-5Ti } \\
\text { with } 900^{\circ} \mathrm{C} \\
\text { treatment }\end{array}$} & \multirow[t]{6}{*}{ None } & \multirow{6}{*}{$\begin{array}{c}\text { High } \\
\text { resistance }\end{array}$} & 42.72 & 0.36 & 204.57 & 8.07 \\
\hline & & & & 84.87 & 1.18 & 210.59 & 7.45 \\
\hline & & & & 157.47 & 3.64 & 210.97 & 6.97 \\
\hline & & & & 42.01 & 0.81 & 343.43 & 23.78 \\
\hline & & & & 83.67 & 2.74 & 338.46 & 22.11 \\
\hline & & & & 143.69 & 7.29 & 326.18 & 20.67 \\
\hline \multirow[t]{6}{*}{3} & \multirow{6}{*}{$\begin{array}{l}\text { AlN coating on } \\
\text { V-5Cr-5Ti } \\
\text { with } 900^{\circ} \mathrm{C} \\
\text { treatment }\end{array}$} & \multirow{6}{*}{$\begin{array}{l}600 \mathrm{~h} \text { at } 300^{\circ} \mathrm{C}, \\
\text { normal purity } \\
\text { (Run 2-8) }\end{array}$} & \multirow{6}{*}{$\begin{array}{l}\text { High } \\
\text { resistance }\end{array}$} & 41.37 & 0.60 & 244.63 & 17.69 \\
\hline & & & & 80.67 & 1.99 & 247.49 & 17.03 \\
\hline & & & & 147.59 & 6.35 & 255.21 & 17.23 \\
\hline & & & & 42.46 & 0.85 & 385.99 & 23.34 \\
\hline & & & & 84.07 & 2.74 & 383.47 & 20.55 \\
\hline & & & & 141.95 & 7.23 & 375.75 & 19.92 \\
\hline \multirow[t]{6}{*}{4} & \multirow{6}{*}{$\begin{array}{l}\text { AlN coating on } \\
\text { prealuminized } \\
\mathrm{V}-5 \mathrm{Cr}-5 \mathrm{Ti} \\
\text { with } 900^{\circ} \mathrm{C} \\
\text { treatment }\end{array}$} & \multirow{6}{*}{$\begin{array}{l}600 \mathrm{~h} \text { at } 300^{\circ} \mathrm{C} \\
\text { normal purity } \\
\text { (Run 2-8) }\end{array}$} & \multirow{6}{*}{$\begin{array}{c}\text { High } \\
\text { resistance }\end{array}$} & 44.53 & 0.36 & 210.44 & 7.53 \\
\hline & & & & 86.59 & 1.34 & 235.17 & 7.33 \\
\hline & & & & 159.15 & 3.94 & 235.88 & 7.32 \\
\hline & & & & 43.53 & 0.88 & 370.03 & 23.37 \\
\hline & & & & 86.18 & 3.01 & 376.84 & 22.19 \\
\hline & & & & 138.01 & 7.26 & 378.70 & 21.81 \\
\hline \multirow[t]{6}{*}{5} & \multirow{6}{*}{$\begin{array}{l}\text { AlN coating on } \\
\text { V-5Cr-5Ti } \\
\text { with } 700^{\circ} \mathrm{C} \\
\text { treatment }\end{array}$} & \multirow{6}{*}{$\begin{array}{l}456 \mathrm{~h} \text { at } 300^{\circ} \mathrm{C} \\
\text { normal purity } \\
\text { (Run 2-9) }\end{array}$} & \multirow{6}{*}{$\begin{array}{l}\text { Partially } \\
\text { resistive }\end{array}$} & 43.97 & 0.57 & 206.90 & 15.07 \\
\hline & & & & 88.41 & 2.05 & 205.56 & 14.93 \\
\hline & & & & 162.41 & 6.47 & 203.92 & 14.74 \\
\hline & & & & 45.55 & 1.20 & 399.97 & 30.17 \\
\hline & & & & 87.88 & 3.73 & 382.32 & 27.55 \\
\hline & & & & 129.47 & 7.25 & 406.8 & 25.97 \\
\hline \multirow[t]{6}{*}{6} & \multirow{6}{*}{$\begin{array}{l}\text { AlN coating on } \\
\text { prealuminized } \\
\text { V-5Cr-5Ti } \\
\text { with } 700^{\circ} \mathrm{C} \\
\text { treatment }\end{array}$} & \multirow{6}{*}{$\begin{array}{l}456 \mathrm{~h} \text { at } 300^{\circ} \mathrm{C} \\
\text { normal purity } \\
\text { (Run 2-9) }\end{array}$} & \multirow{6}{*}{$\begin{array}{l}\text { High } \\
\text { resistance }\end{array}$} & 43.69 & 0.38 & 203.71 & 8.54 \\
\hline & & & & 87.75 & 1.34 & 211.65 & 8.06 \\
\hline & & & & 162.23 & 4.00 & 205.61 & 7.34 \\
\hline & & & & 44.84 & 0.77 & 283.56 & 19.56 \\
\hline & & & & 88.57 & 2.63 & 320.12 & 17.85 \\
\hline & & & & 147.14 & 7.27 & 371.05 & 18.23 \\
\hline \multirow[t]{3}{*}{7} & Fused silica & - & - & 42.40 & 0.28 & 73.80 & 10.62 \\
\hline & & & & 84.66 & 0.98 & 72.57 & 10.23 \\
\hline & & & & 156.61 & 3.22 & 74.51 & 10.37 \\
\hline
\end{tabular}

avalues in first three rows correspond to substrate material, and next three rows correspond to coatings in each set of data. 


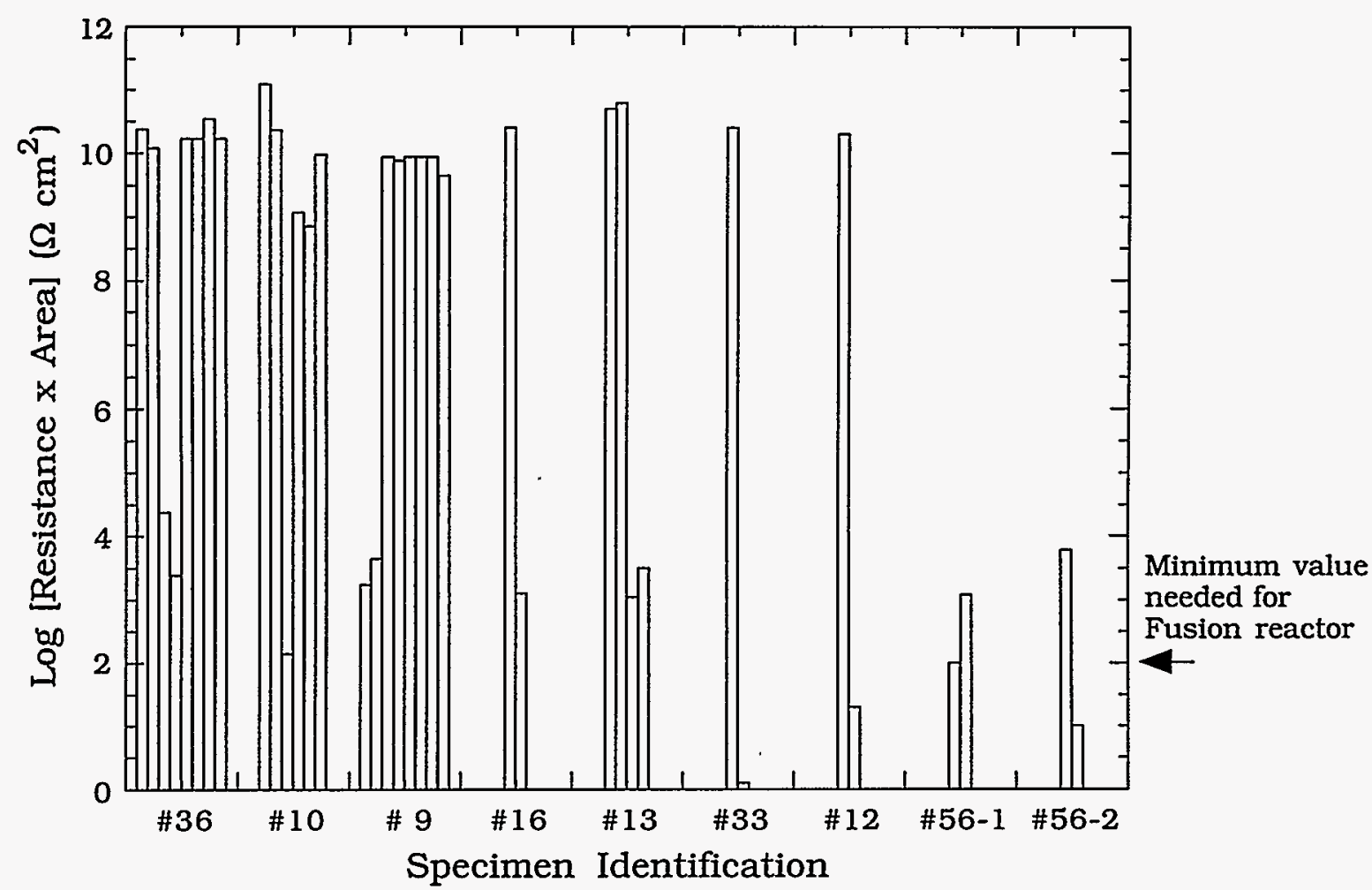

Key to Specimen Treatment

\#36: V-5Cr-5Ti alloy, AlN coated

\#10: Alloy, AlN coated, hardened for $110 \mathrm{~h}$ at $900^{\circ} \mathrm{C}$

\# 9: Alloy, AlN coated, hardened for $110 \mathrm{~h}$ at $900^{\circ} \mathrm{C}$, exposed to $\mathrm{Li}$ for $600 \mathrm{~h}$ at $300^{\circ} \mathrm{C}$

\# 16: Alloy, prealuminized, AlN coated, hardened for $110 \mathrm{~h}$ at $900^{\circ} \mathrm{C}$

\#13: Alloy, prealuminized, AlN coated, hardened for $110 \mathrm{~h}$ at $900^{\circ} \mathrm{C}$, exposed to $\mathrm{Li}$ for $600 \mathrm{~h}$ at $300^{\circ} \mathrm{C}$

\#33: Alloy, AlN coated, hardened for $284 \mathrm{~h}$ at $700^{\circ} \mathrm{C}$, exposed to $\mathrm{Li}$ for $456 \mathrm{~h}$ at $300^{\circ} \mathrm{C}$

\#12: Alloy, prealuminized, AlN coated, hardened for $284 \mathrm{~h}$ at $700^{\circ} \mathrm{C}$, exposed to Li for $456 \mathrm{~h}$ at $300^{\circ} \mathrm{C}$ \#56-1: Alloy, AlN coated by 2nd vendor, hardened for $110 \mathrm{~h}$ at $900^{\circ} \mathrm{C}$, exposed to $\mathrm{Li}$ for $600 \mathrm{~h}$ at $300^{\circ} \mathrm{C}$ \#56-2: Alloy, AlN coated by 2nd vendor, hardened for $284 \mathrm{~h}$ at $700^{\circ} \mathrm{C}$, exposed to $\mathrm{Li}$ for $456 \mathrm{~h}$ at $300^{\circ} \mathrm{C}$

Fig. 27. Electrical resistance of several AlN-coated specimens in as-coated and hardened conditions before and after Li exposure

Figure 28 shows a macrophotograph of bullet specimens in the ascoated condition and after exposure to a Li environment. Figure 29 shows SEM photomicrographs of the as-coated bullet along the circumference at 0 , 90,180 , and $270^{\circ}$ orientations. It is evident that the coating is fairly uniform around the circumference of the bullet and appears fairly dense and bonded to the substrate. The appearance of the coating in the bullet specimen is similar to that on a flat coupon (see Fig. 30) that was coated along with the bullet specimens. 


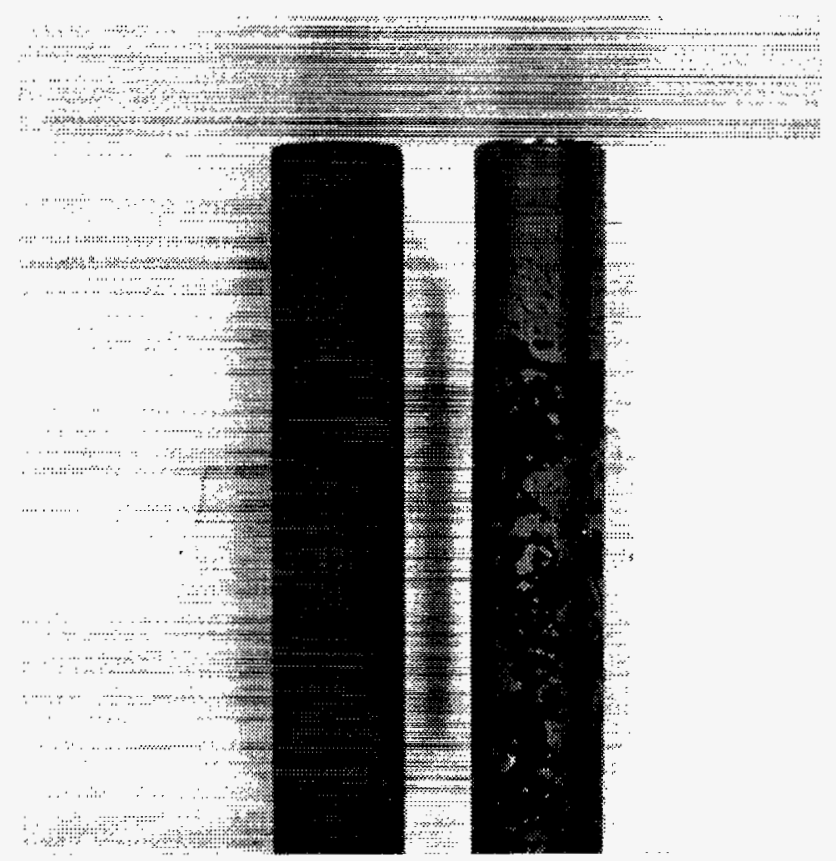

Fig. 28. Macrophotograph of AlNcoated bullet specimens (left) in as-coated condition and (right) after exposure to Li environment
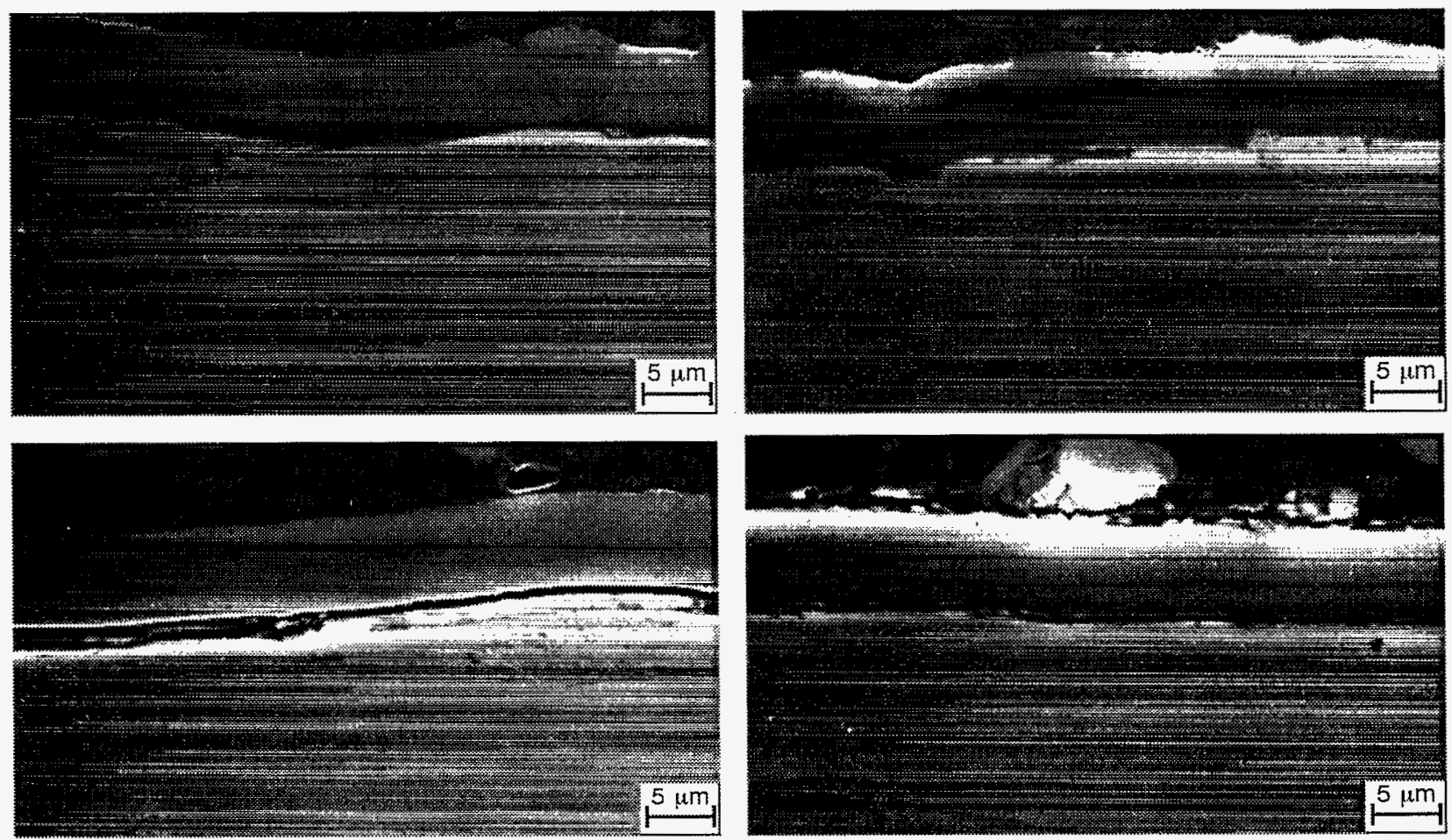

Fig. 29. SEM photomicrographs of cross sections of as-coated bullet along circumference at $0,90,180$, and $270^{\circ}$ orientations 


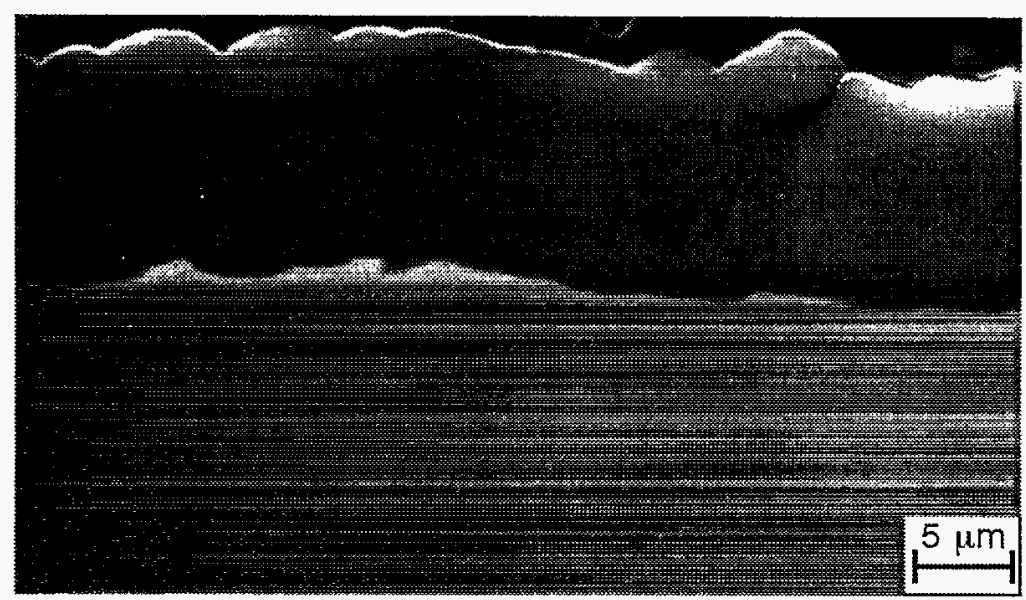

Fig. 30. SEM photomicrograph of cross section of flat coupon coated with AlN along with bullet specimens
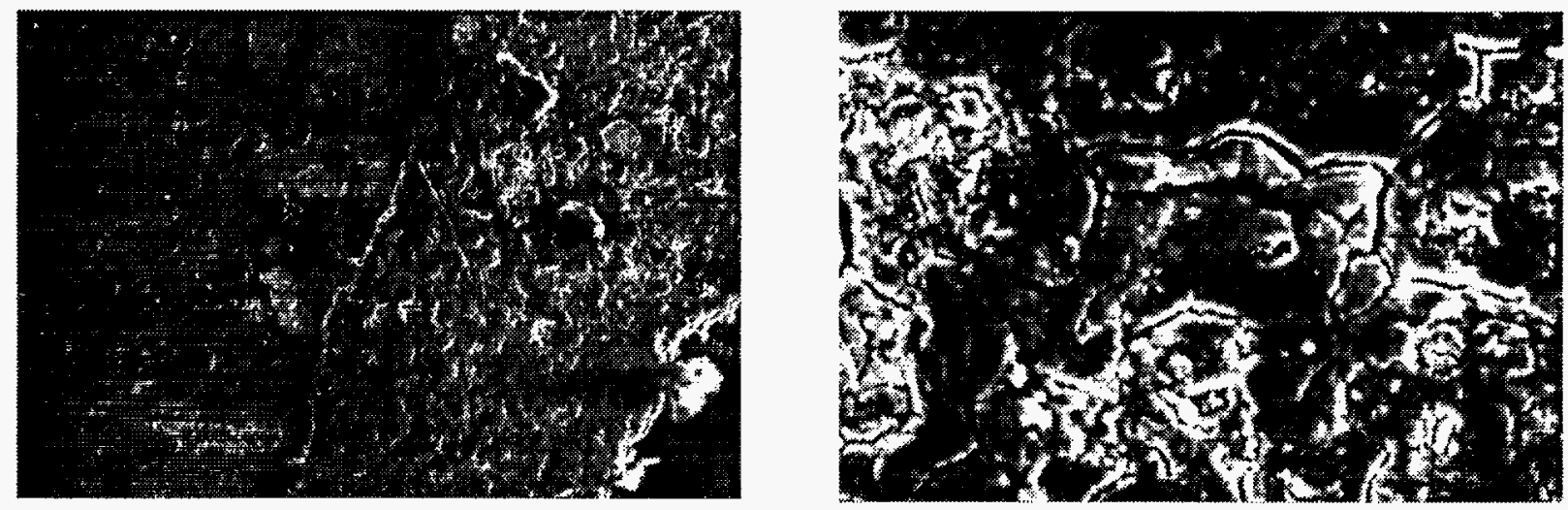

Fig. 31. SEM photomicrographs of surface of Li-exposed bullet specimen showing crack network

In Bullet test $I$, the coated specimen in as-coated condition was inserted in $\mathrm{Li}$ at $300^{\circ} \mathrm{C}$. Coating resistance before insertion was $1.2 \times 10^{5} \Omega$ but decreased to zero immediately after insertion into $\mathrm{Li}$, indicating local spallation of the coating during Li exposure. In Bullet test II, the specimen was given a thermal/chemical treatment at $900^{\circ} \mathrm{C}$ prior to insertion in $\mathrm{Li}$. The resistance of the coating was $20,000 \Omega$ prior to $\mathrm{Li}$ exposure but decreased and reached $0 \Omega$ within 5 min after insertion into Li. Figure 31 shows SEM photomicrographs of the unspalled coating in the Li exposed specimen indicating a network of fine cracks in the coating. However, postexposure $\mathrm{X}$-ray diffraction analysis of the bullets (prior to.washing in alcohol and water) showed that the coating beneath the $\mathrm{Li}$ was intact and had high resistance; this indicates that the Li itself did not contribute to coating failure but that a combination of oxygen impurity in the coating and 
thermally induced local spalling resulted in inadequate electrical resistance for the coating. Additional tests are planned to address these issues.

\section{In-Situ Development of AlN Coatings in $\mathrm{Li}$}

Even though AlN coatings developed by PVD had potential as electrically insulating coatings, the ultimate objective is to develop the coating in-situ in $\mathrm{Li}$ by controlling the $\mathrm{N}$ and/or $\mathrm{Al}$ activity in $\mathrm{Li}$. To examine this approach, an attempt was made to increase the $\mathrm{N}$ and $\mathrm{Al}$ activity in $\mathrm{Li}$ by adding $100 \mathrm{~g}$ of fine powder of AlN at $300^{\circ} \mathrm{C}$ and the $\mathrm{Li}$ was heated to $500^{\circ} \mathrm{C}$ for $24 \mathrm{~h}$ to equilibrate the $\mathrm{Li}$ with dissolved $\mathrm{Al}$ and $\mathrm{N}$. Specimens of $\mathrm{V}$ alloy with and without prealuminization and MRT-developed AlN coatings in as-coated condition were exposed in Run 3-7 for 24 and $620 \mathrm{~h}$ to examine whether either $\mathrm{N}$ and/or Al transferred to the alloy surface or the coating reacted with $\mathrm{Li}$. The results showed no significant transfer of either $\mathrm{N}$ or $\mathrm{Al}$ from $\mathrm{Li}$ to the alloy, as evidenced by resistance measurements and SEM analysis of the specimens. The specimen coatings were insulating on one side of the specimen but tended to flake off from the other side of the specimens. Based on these results, it was concluded that the dissociation of AlN in $\mathrm{Li}$ may be a slow process even at $500^{\circ} \mathrm{C}$ and that an alternate method is needed to increase $\mathrm{N}$ and $\mathrm{Al}$ activities.

Because $\mathrm{Al}$ and $\mathrm{N}$ have high solubilities in liquid $\mathrm{Li}$, an increase in activities of these elements in $\mathrm{Li}$ was obtained by additions of solid $\mathrm{Al}$ and Li3N. Additions of $14.2 \mathrm{~g}$ of $\mathrm{Al}$ and $25.5 \mathrm{~g} \mathrm{Li} 3 \mathrm{~N}$ yielded $\mathrm{Al}$ and $\mathrm{N}$ concentrations of 4057 and 2929 wtppm, respectively. Even if all the Al reacted to form AlN, the $\mathrm{N}$ concentration in $\mathrm{Li}$ in excess of AlN was 825 ppm. Subsequent to these additions, the $\mathrm{Li}$ was maintained at $500^{\circ} \mathrm{C}$ for 120 $\mathrm{h}$ to equilibrate the system. Specimens of $\mathrm{V}$ alloy with and without prealuminization and several specimens of thermally/chemically treated AlN-coatings on $\mathrm{V}$ alloy substrate were exposed in $\mathrm{Li}$ for $120 \mathrm{~h}$ at $500^{\circ} \mathrm{C}$ in Run 3-8. Two major observations were noted from a detailed analysis of the exposed specimens from this run. The first, no transfer of either $\mathrm{N}$ or $\mathrm{Al}$, was observed from lithium towards the bare and prealuminized V-alloy specimens. The second, the thermally treated coatings of AlN, performed well and had high resistivity values. Further, no surface reactions were noted between the coating and the $\mathrm{Li}$ or impurities in $\mathrm{Li}$, even though the temperature was as high as $500^{\circ} \mathrm{C}$. Figure 32 shows SEM photomicrographs of several AlN-coated specimens tested in Run 3-8.

Subsequently, the $\mathrm{Li}$ temperature in the vessel was lowered to $300^{\circ} \mathrm{C}$ and additional specimens of $\mathrm{V}$ alloy with and without prealuminization, several AlN-coated specimens with thermal/chemical treatment, and a "hotdip" Al coated V alloy specimen were exposed to $\mathrm{Li}$ for $120 \mathrm{~h}$ in Run 3-9. 

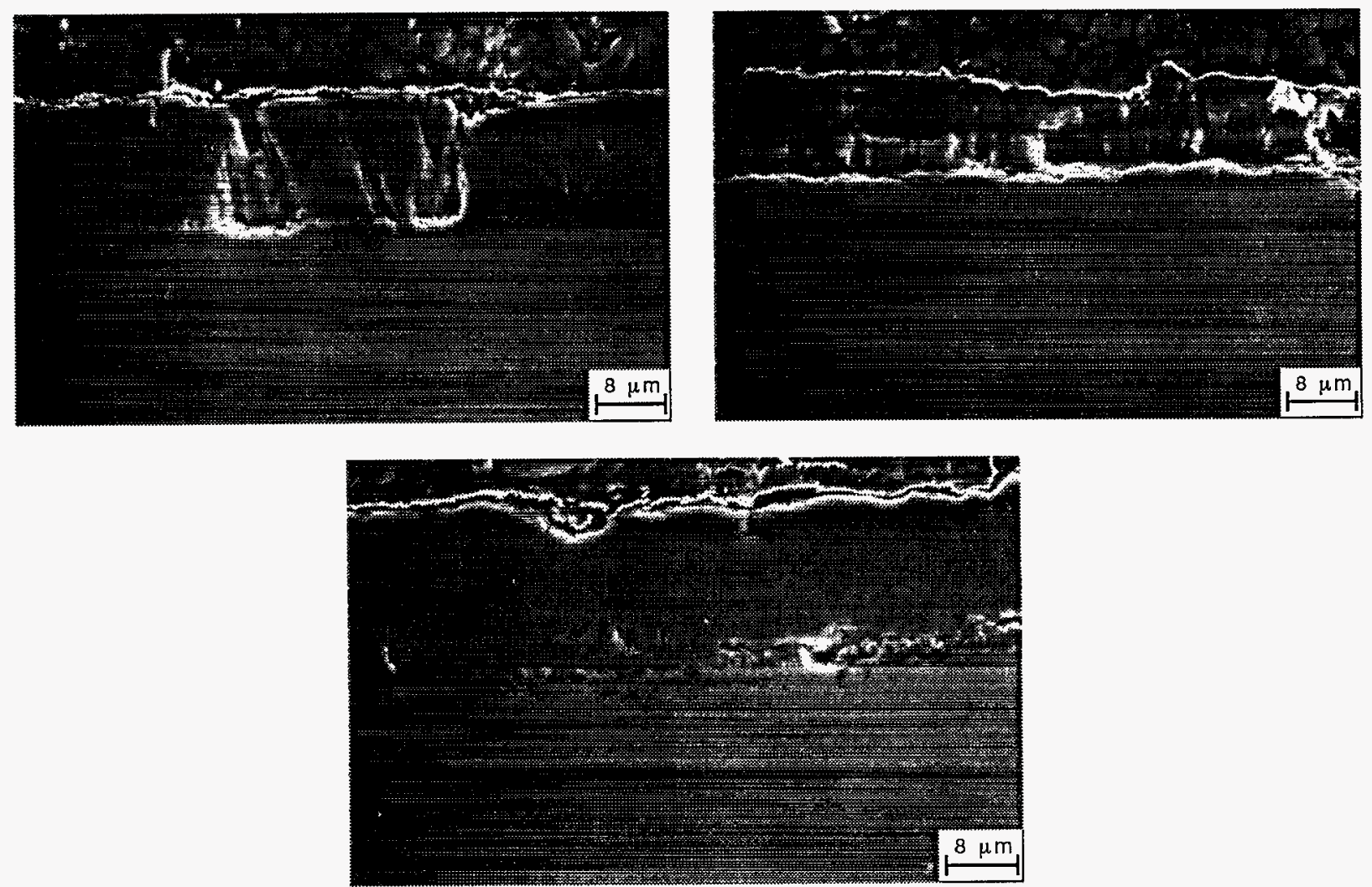

Fig. 32. SEM photomicrographs of cross sections of several AlN-coated specimens after $120 \mathrm{~h}$ exposure in Run $3-8$ at $500^{\circ} \mathrm{C}$ to $\mathrm{Li}$ environment with $\mathrm{N}$ and $\mathrm{Al}$ additions

For the same $\mathrm{N}$ and $\mathrm{Al}$ concentrations in $\mathrm{Li}$, the thermodynamic activities of these elements in $\mathrm{Li}$ will be much higher at $300^{\circ} \mathrm{C}$ than at $500^{\circ} \mathrm{C}$. Analysis of exposed specimens still showed no transfer of $\mathrm{N}$ or $\mathrm{Al}$ to the $\mathrm{V}$ alloy specimens. All of the AlN-coated specimens performed well in terms of their physical characteristics (see Fig. 33) and exhibited high electrical resistivity. The "hot-dip" specimen, which had a poorly adhered Al layer initially, exhibited complete loss of Al from the surface after exposure to Li.

A significant difference in the microstructures of the coatings is seen between specimens exposed to $\mathrm{Li}$ of normal purity and those exposed in $\mathrm{Li}$ with deliberate additions of $\mathrm{Al}$ and $\mathrm{N}$. In the former, the surface regions of the coatings reacted with $\mathrm{Li}$ or impurities in $\mathrm{Li}$, resulting in a layer that was rich in $\mathrm{O}, \mathrm{Al}$, and probably Li (see SEM photographs in Figs. 22 and 23). In the case of specimens exposed to $\mathrm{Li}$ containing added $\mathrm{N}$ and $\mathrm{Al}$, no such interaction layer was observed (see Figs. 32 and 33).

To examine the thermodynamic stability of AlN in $\mathrm{Li}$ and the possible reactions between the AlN coating and $O$ in $\mathrm{Li}$, calculations were made to 
evaluate the regions in terms of $\mathrm{O}$ and $\mathrm{N}$ in $\mathrm{Li}$ in which AlN will be stable in contact with $\mathrm{Li}$. AlN can react with $\mathrm{O}$ in $\mathrm{Li}$ via three possible reactions:

$$
\begin{aligned}
& 5 \mathrm{AlN}(\mathrm{s})+8 \mathrm{O}(\mathrm{Li})+\mathrm{Li}(1)=\mathrm{LiAl}_{5} \mathrm{O} 8+5 \mathrm{~N}(\mathrm{Li}) \\
& \mathrm{AlN}(\mathrm{s})+2 \mathrm{O}(\mathrm{Li})+\mathrm{Li}(\mathrm{l})=\mathrm{LiAlO}_{2}+\mathrm{N}(\mathrm{Li}) \\
& 2 \mathrm{AlN}(\mathrm{s})+3 \mathrm{O}(\mathrm{Li})+\mathrm{Li}(\mathrm{l})=\mathrm{Al}_{2} \mathrm{O}_{3}+2 \mathrm{~N}(\mathrm{Li})
\end{aligned}
$$

Based on knowledge of free energy of formation of AlN and various oxides, calculations were made to establish the minimum $\mathrm{N}$ concentration in $\mathrm{Li}$ required for AlN to be stable at several $O$ concentrations in Li. Figures 34-36 show plots of $\mathrm{N}$ concentration as a function of temperature for reactions (4) -(6) at $O$ levels of $1,10,100$, and $1000 \mathrm{wppm}$ in Li. Also shown in the figures is a curve for $O$ level in $\mathrm{Li}$ corresponding to a cold-trap temperature of $200^{\circ} \mathrm{C}$. In these figures, for a given $\mathrm{O}$ concentration in $\mathrm{Li}$, AlN will be stable in the region above the line and the oxide phase will be stable in the region below the line. The curves also indicate that for a given temperature and at a given $\mathrm{O}$ concentration in $\mathrm{Li}$, there exists a definite concentration of $\mathrm{N}$ in Li below which the oxidation of AlN will occur.

For example, at $300^{\circ} \mathrm{C}$ and $100 \mathrm{ppm} \mathrm{O}$ in $\mathrm{Li}$, the minimum $\mathrm{N}$ concentration needed to maintain stable AlN is 5000, 4000, and $0.1 \mathrm{wppm}$, based on reactions (4), (5), and (6), respectively. In Li of normal purity
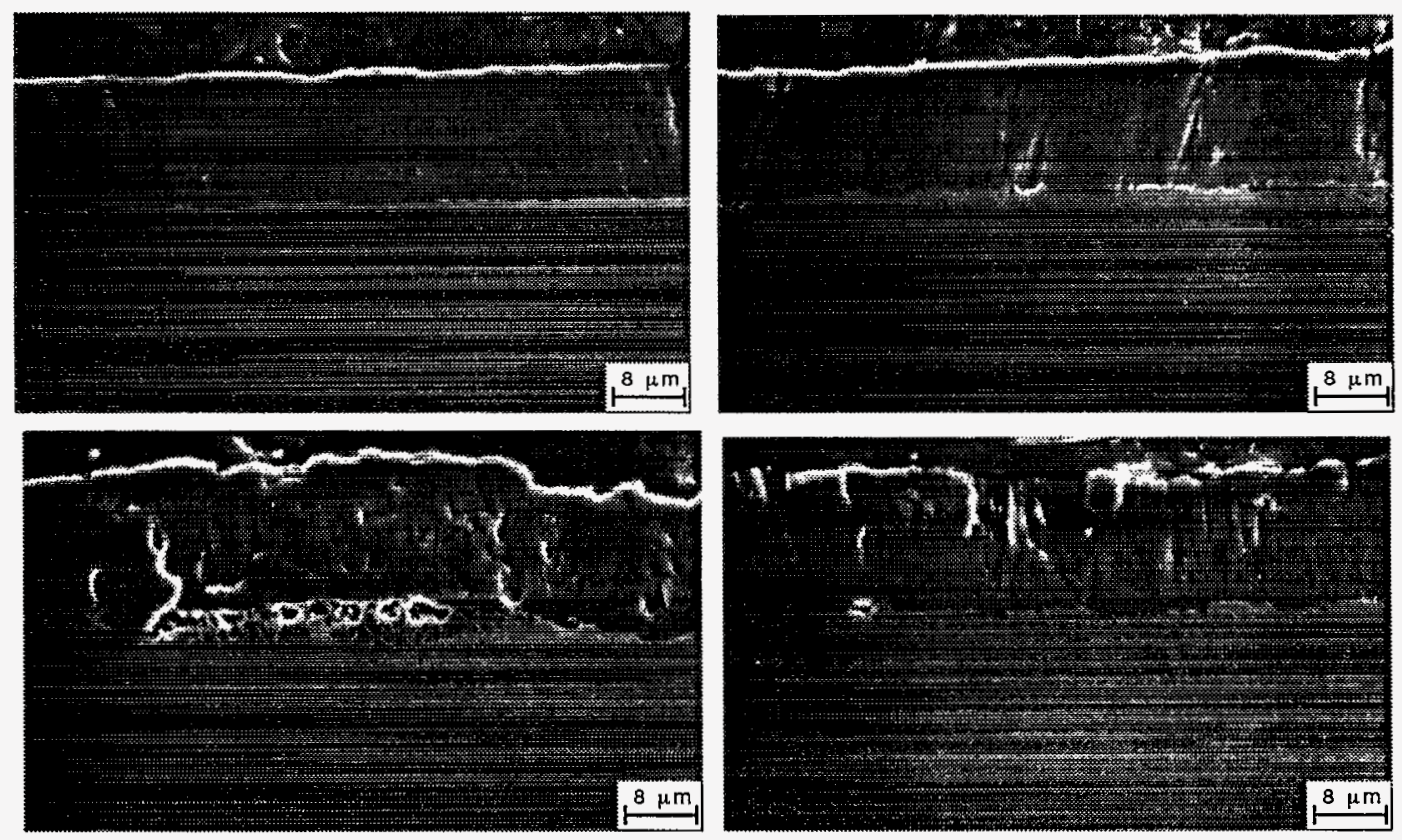

Fig. 33. SEM photomicrographs of cross sections of several AlNcoated specimens after $120 \mathrm{~h}$ exposure in Run $3-9$ at $300^{\circ} \mathrm{C}$ to $\mathrm{Li}$ environment with $\mathrm{N}$ and $\mathrm{Al}$ additions 
(without a cold trap), the $O$ and $N$ concentrations are generally $\approx 100 \mathrm{wppm}$ each. Under these conditions, the AIN coating will not react to form $\mathrm{Al}_{2} \mathrm{O}_{3}$ but will react to form either $\mathrm{LiAl}_{5} \mathrm{O}_{8}$ or $\mathrm{LiAlO}_{2}$. This confirms the SEM and EDX analysis of the reaction phases observed in the present experiments. Extensive analysis of the coatings before and after $\mathrm{Li}$ exposure is presently being conducted by the Rutherford backscattering technique (RBS). The calculations also indicate that at a higher temperature of $500^{\circ} \mathrm{C}$ and an oxygen concentration in $\mathrm{Li}$ of $100 \mathrm{wppm}$, the $\mathrm{N}$ concentrations in $\mathrm{Li}$ needed to maintain AlN as a stable phase are 900,200 , and $0.08 \mathrm{ppm}$, based on reactions (4), (5), and (6), respectively. The data also show that at $500^{\circ} \mathrm{C}$ and for an $\mathrm{O}$ concentration in $\mathrm{Li}$ cold-trapped at $200^{\circ} \mathrm{C}$, the $\mathrm{N}$ concentrations are 180,30, and $0.02 \mathrm{wppm}$, based on reactions (4), (5), and (6), respectively. These calculations clearly demonstrate the importance of controlling and maintaining low $\mathrm{O}$ levels in $\mathrm{Li}$ for the nitride coating to perform adequately. Further, such control of $\mathrm{O}$ in $\mathrm{Li}$ is essential for the insitu development of AlN coatings by transfer of $\mathrm{Al}$ and $\mathrm{N}$ from $\mathrm{Li}$ to the $\mathrm{V}$ alloy surface. The calculations also indicate the importance of experiments in a flowing system, in which the impurity levels can be effectively controlled by a cold trap, in contrast with experiments in either small capsules or in static vessels, as in present experiments.

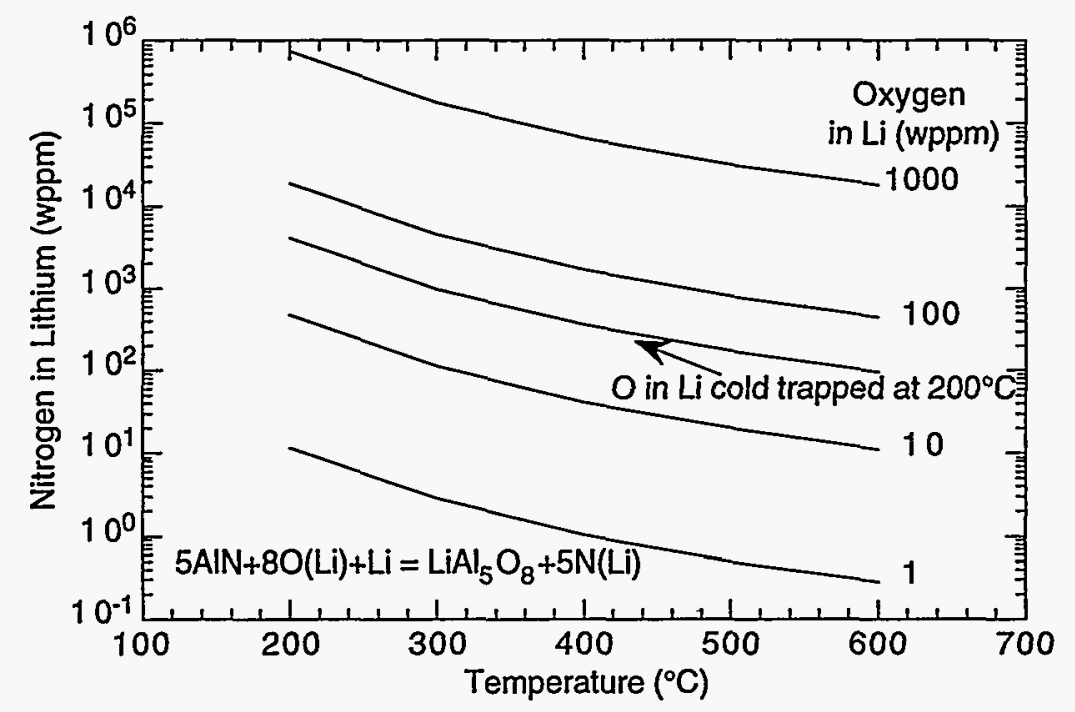

Fig. 34. Regions of stability for $\mathrm{AlN}$ and $\mathrm{LiAl}_{5} \mathrm{O}_{8}$ phases as a function of temperature and $O$ and $\mathrm{N}$ concentrations in $\mathrm{Li}$ 


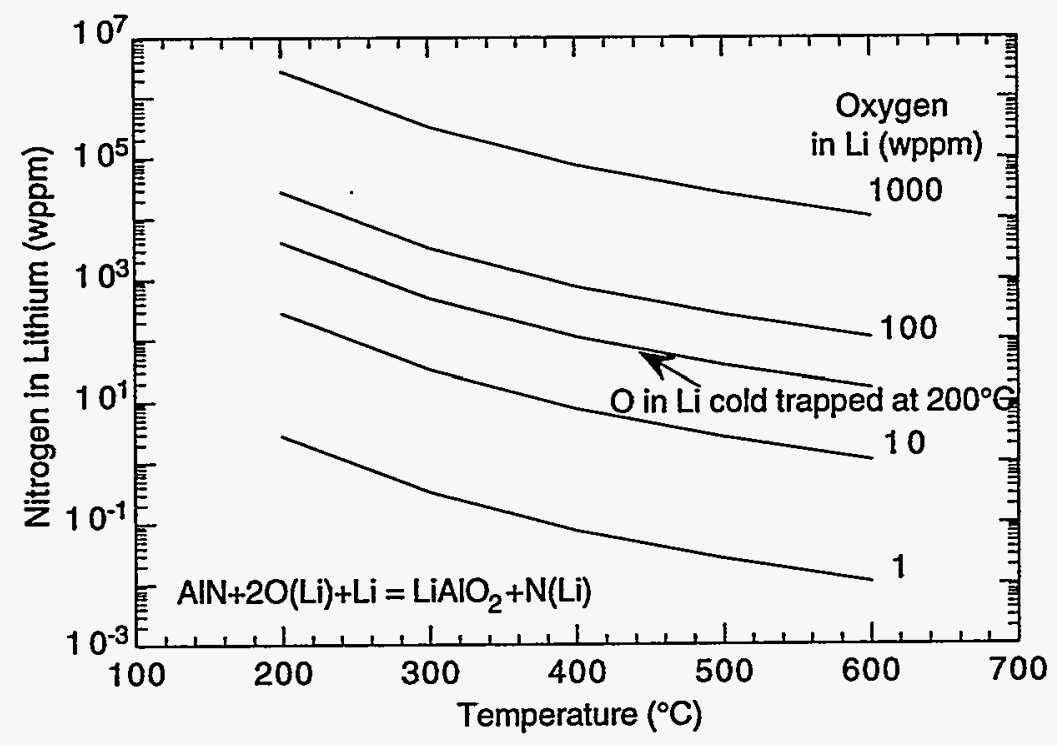

Fig. 35. Regions of stability for AlN and $\mathrm{LiAlO}_{2}$ phases as a function of temperature and $\mathrm{O}$ and $\mathrm{N}$ concentrations in $\mathrm{Li}$

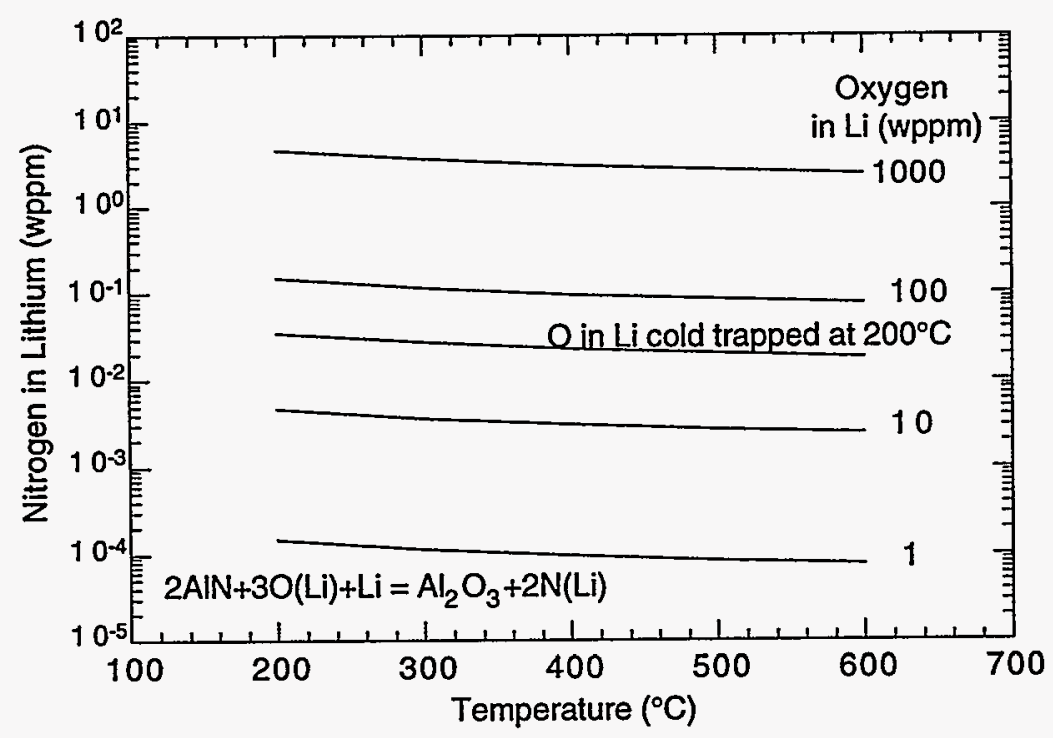

Fig. 36. Regions of stability for $\mathrm{AlN}$ and $\mathrm{Al}_{2} \mathrm{O}_{3}$ phases as a function of temperature and $\mathrm{O}$ and $\mathrm{N}$ concentrations in $\mathrm{Li}$ 


\section{SUMMARY}

Detailed investigations were conducted on the fabrication, metallurgical microstructure, compatibility in liquid $\mathrm{Li}$, and electrical characteristics of AIN material obtained from several sources. Coating fabrication methods included gas-phase nitridation, physical vapor deposition, reaction sputtering, ion-beam-assisted deposition, chemical vapor deposition, and a chemical route. Microstructural characterization of the coated samples was conducted by scanning electron microscopy, energy-dispersive X-ray analysis, and X-ray diffraction. A nano-indentation technique was used to evaluate the hardness of the coated samples in as-coated condition after a hardening treatment and after exposure to Li. Lithium compatibility studies were conducted in static systems by exposure of AlN-coated specimens over several time periods. Electrical resistance measurements were made at room temperature on the specimens before and after exposure to liquid lithium. Experiments were initiated to develop AlN coatings in-situ in Li by adjusting the $\mathrm{Al}$ and/or $\mathrm{N}$ activities in $\mathrm{Li}$. Several conclusion can be drawn from the study:

1) Coatings of AlN on V alloy substrate can be successfully prepared by PVD. Processes that involve CVD and chemical routes have potential, but substantial additional effort is needed to obtain reliable, crack-free coatings. Gas-phase nitridation has limitations unless the oxygen content of the exposure environment is substantially reduced.

2) Coatings developed by PVD need a thermal/chemical hardening treatment to improve the adhesion characteristics and probably reduce the porosity of the coatings. Coating characteristics may be improved if the substrate temperature is increased during the coating process.

3) Experiments conducted with PVD-developed AlN coatings showed adequate chemical compatibility in Li of normal purity. They also retained their insulating properties after exposure to $\mathrm{Li}$. However, the coating surfaces reacted with $\mathrm{Li}$ to form ternary oxides of $\mathrm{Li}, \mathrm{Al}$, and $\mathrm{O}$, whose growth rates are not established.

4) An endurance test of $5000 \mathrm{~h}$ exposure in $\mathrm{Li}$ of normal purity showed the coating to be adherent and have high resistance after $\mathrm{Li}$ exposure.

5) The effect of increased $N$ content, in the range of the present study, in the $\mathrm{Li}$ environment on the coating performance was minimal.

6) Hardness measurements made by nano-indentation seems to indicate that the absolute values of the hardness for the coating, rather than 
the difference in hardness between the coating and the substrate, may play a role in adhesion and spallation.

7) Measurement of coating resistance in-situ needs significant additional effort; the impurity content (such as $O$ ) of the coating and thermal cycling effects are considered important.

8) Development of AlN coatings in-situ in $\mathrm{Li}$ needs additional effort. It has been established that for a given exposure temperature and $O$ concentration in $\mathrm{Li}$, there exists a minimum value for $\mathrm{N}$ concentration in $\mathrm{Li}$ below which the AlN will react to form binary or ternary oxides with Li and Al. This minimum $\mathrm{N}$ concentration decreases with an increase in temperature.

9) AlN is a viable coating with adequate electrical resistivity for application as an insulator coating for the blanket in a fusion reactor system.

\section{ACKNOWLEDGMENTS}

The authors thank J. Kammer of MRT, M. Graham, C. West, G. Nichols of BIRL, T. Selinder of ANL, and P. Gierszewski of the Canadian Fusion Fuels Technology Project for assistance in development and/or supply of coated specimens. At Argonne National Laboratory, C. Reed and R. C. Haglund assisted with the construction and operation of liquid metal test facilities; $B$. Tani and M. Lanagan assisted with X-ray diffraction analysis of specimens.

\section{REFERENCES}

1. K. Natesan, "Development of Aluminum Nitride Insulator Coatings for Fusion. Reactor Applications," Argonne National Laboratory Report ANL/FPP/TM-278 (1995).

2. K. Natesan, C. B. Reed, and R. F. Mattas, "Assessment of alkali metal coolants for the ITER blanket," Fusion Engineering and Design, 27 (1995) 457-466.

3. S. Malang, H. U. Borgstedt, E. H. Farnum, K. Natesan, and I. V. Vitkovski, "Development of insulating coatings for liquid metal blankets," ibid.

4. S. Malang and L. Bühler, "MHD pressure drop in ducts with imperfectly insulating coatings," Argonne National Laboratory Report ANL/FPP/TM269 (August 1994).

5. C. B. Reed, K. Natesan, T. Q. Hua, I. R. Kirillov, I. V. Vitkovski, and A. Anisimov, "Experimental and theoretical MHD performance of a 
round pipe with a NaK-compatible $\mathrm{Al}_{2} \mathrm{O}_{3}$ coating," Fusion Engineering and Design, 27 (1995) 614-626.

6. D. L. Smith and K. Natesan, "Influence of nonmetallic impurity elements on the compatibility of liquid lithium with potential CTR containment materials," Nucl. Technol. 22, 392 (1974).

7. K. Natesan, "Influence of nonmetallic elements on the compatibility of structural materials with liquid alkali metals," J. Nucl. Mater. 115, 251262 (1983).

8. K. Natesan and D. L. Smith, "Effectiveness of tritium removal from a CTR lithium blanket by cold trapping secondary liquid metals $\mathrm{Na}, \mathrm{K}$, and NaK," Nucl. Technol. 22, 138 (1974).

9. H. U. Borgstedt, KfK, Germany, private communication.

10. L. V. Interrante, L. E. Carpenter II, C. Whitmarsh, and W. Lee, "Studies of Organometallic Precursors to Aluminum Nitride," Mat. Res. Soc. Symp. Proc. 73, 359, 1986.

11. M. E. Bartram, T. A. Michalske, and J. W. Rogers, Jr., "Nucleation and Growth of AlN: Self-Limiting Reactions and the Regeneration of Active Sites Using Sequential Exposures of Trimethylaluminum and Ammonia on Silica at 600 K," Chem. Mater. 5, 1424, 1993.

12. D. C. Bertolet, H. Liu, and J. W. Rogers, Jr., "Mechanics of Early Stage Growth of AlN on Alumina," Chem. Mater. 5, 1814, 1993. 


\section{Internal}

M. Billone

H. Drucker

D. Ehst

Y. Gohar

A. Hassanein

T. Hua

T. F. Kassner

M. Lineberry
S. Majumdar

C. Malefyt

R. F. Mattas (5)

K. Natesan (20)

J.-H. Park

R. B. Poeppel

C. Reed

D. L. Rink

W. J. Shack
Dale L. Smith

Donald L.

Smith

D.-K. Sze

C. E. Till

H. Tsai

R. W. Weeks

FPP Files (10)

TIS Files

\section{External}

DOE/OSTI for distribution per UC-424 (41)

Manager, Chicago Operations Office

Libraries

ANL-E

ANL-W

Energy Technology Division Review Committee:

H. K. Birnbaum, University of Illinois, Urbana

R. C. Buchanan, University of Cincinnati, Cincinnati, $\mathrm{OH}$

S. Liu, Fremont, CA

H. Rosenbaum, Fremont, CA

R. Shah, University of Kentucky, Lexington

S. Smialowska, The Ohio State University, Columbus

R. E. Smith, Altran Corporation, Huntersville, NC

M. Abdou, University of California, Los Angeles

J. Anderson, Los Alamos National Laboratory

C. Baker, University of California, San Diego

J. Bartlit, Los Alamos National Laboratory

S. Berk, U.S. Department of Energy

E. E. Bloom, Oak Ridge National Laboratory

T. Burchell, Oak Ridge National Laboratory

R. Causey, Sandia National Laboratories, Livermore

M. Cohen, U.S. Department of Energy

C. Croessman, Sandia National Laboratories, Albuquerque

W. Daenner, ITER, München, Germany

J. Davis, McDonnell Douglas Astronautics Company, St. Louis

J. Doggett, Lawrence Livermore National Laboratory

L. El-Guebaly, University of Wisconsin, Madison

D. Gelles, Pacific Northwest National Laboratory

N. Ghoneim, University of California, Los Angeles

H. Glassbrenner, Forschungszentrum Karlsruhe, Germany

L. Greenwood, Pacific Northwest National Laboratory 
R. H. Jones, Pacific Northwest National Laboratory

G. Kulcinski, University of Wisconsin, Madison

D. Lousteau, Fusion Engineering Design Center, Oak Ridge, TN

H. Maekawa, Japan Atomic Energy Research Institute

S. Malang, Forschungszentrum Karlsruhe, Germany

R. McGrath, Sandia National Laboratories, Albuquerque

D. Muntz, Forschungszentrum Karlsruhe, Germany

R. Nygren, Sandia National Laboratories, Albuquerque

A. Opdenaker, U.S. Department of Energy

R. Parker, ITER JCT, Garching, Germany

S. Piet, ITER JCT, San Diego

D. Post, ITER JCT, San Diego

R. Price, U.S. Department of Energy

A. Raffray, ITER JCT, Garching, Germany

M. Sawan, University of Wisconsin, Madison

K. Schultz, General Atomics, San Diego

M. Seki, Japan Atomic Energy Research Institute

D. Steiner, Rensselaer Polytechnic Institute

J. Stringer, Electric Power Research Instiutute, Palo Alto, CA

I. Sviatoslavsky, University of Wisconsin, Madison

M. Tillack, University of California, San Diego

J. Vetter, Forschungszentrum Karlsruhe, Germany

G. Vieider, ITER, München, Germany

R. Watson, Sandia National Laboratories, Albuquerque

F. W. Wiffen, U.S. Department of Energy

L. Wittenberg, University of Wisconsin, Madison

K. Wilson, Sandia National Laboratories, Livermore

Bibliothek, Max-Planck-Institut für Plasmaphysik, Germany

C.E.A. Library, Fontenay-aux-Roses, France

Librarian, Culham Laboratory, England

Thermonuclear Library, Japan Atomic Energy Research Institute 